\begin{abstract}
UNIVERSIDADE DE SÃO PAULO
FACULDADE DE FILOSOFIA, LETRAS DE CIÊNCIAS HUMANAS

DEPARTAMENTO DE LINGÜÍSTICA

PROGRAMA DE PÓS-GRADUAÇÃO EM SEMIÓTICA E LINGÜÍSTICA
\end{abstract}

MARIA DE FÁTIMA DE ALMEIDA BAIA

O MODELO PROSÓDICO INICIAL DO PORTUGUÊS BRASILEIRO: UMA QUESTÃO METODOLÓGICA?

São Paulo 


\author{
UNIVERSIDADE DE SÃO PAULO \\ FACULDADE DE FILOSOFIA, LETRAS DE CIÊNCIAS HUMANAS \\ DEPARTAMENTO DE LINGÜÍSTICA \\ PROGRAMA DE PÓS-GRADUAÇÃO EM SEMIÓTICA E LINGÜÍSTICA
}

\title{
O MODELO PROSÓDICO INICIAL DO PORTUGUÊS BRASILEIRO: UMA QUESTÃO METODOLÓGICA?
}

\author{
Maria de Fátima de Almeida Baia
}

Dissertação apresentada ao Programa de Pós-

Graduação em Lingüística, do Departamento de Semiótica e Lingüística Geral da Faculdade de Filosofia, Letras e Ciências Humanas da Universidade de São Paulo, para a obtenção do título de mestre na área de Semiótica e Lingüística Geral, sob a orientação da $\operatorname{Prof}^{\mathrm{a}} \mathrm{Dr}^{\mathrm{a}}$ Raquel Santana Santos.

São Paulo 
Maria de Fátima de Almeida Baia

Raquel Santana Santos (orientadora) 
Para Rose (in memoriam), que se foi antes do término daquela gangorra, mas deixou as ferramentas necessárias para eu prosseguir... 


\section{AGRADECIMENTOS}

Nada como começar agradecendo a quem de certa forma induziu meus passos para o universo lingüístico, a energia divina que tem colocado pistas nas nuvens e em outros meios simbólicos, no intuito de me indicar alguma seta que me deixe menos perdida no percurso da vida (que se tornou mais alucinante com a chegada da Lingüística!).

Agradeço à minha família (pai Adauzo, mãe Joana, irmã Célia, sobrinha Karine, sobrinho Murilo, cunhado Marcos, primo Moacir e tio Gentil) por ter me erguido nos 'tombos' que levei durante este mestrado.

Agradeço ao Daniel por todo amor, dedicação, amizade e paciência nesses dois anos (por ter cedido alguns dias e semanas para o meu outro pretendente, o mestrado) e à sua família que me adotou.

Às meninas do grupo de estudo: Cris, Eneida, Juliana (pela amizade e conversas transcendentais), Milca (por todo apoio, amizade e a sua risadinha que sempre me deixa para cima). Aos demais amigos do círculo lingüístico: André Xavier (pela enorme força e o som retroflexo apresentado), Fernanda, Francisco, Indaiá (pela amizade e conselhos sábios), Marcus Avelar (pelas repreensões e todo carinho), Paola, Sulemi Campos (pelo incentivo), Susana Correia (pela atenção e troca de figurinhas via Portugal), Walter... Aos que não são lingüistas, mas moram aqui dentro da minha gratidão: Adriana, Andreas, Alê (pela amizade e tranqüilidade), Anna Borodai, Bárbara, Brian, Cartis, Ellionai, Gustavo, Miguel, Natasa, Rapha Aguirra (por ser tão amigo), Sérgio (pelas pedrinhas preciosas que me ajudam sempre) e Vale. A todos do Madrigal Arcadelt por entenderem minhas faltas e o meu afastamento recente do grupo. 
À minha orientadora Raquel Santos, que me orienta desde o início da minha iniciação em 2004, e que me ajudou a tirar a máscara monstruosa dos iambos e troqueus por meio da sua explicação detalhada, inteligência e praticidade. Aos professores: Elaine Grolla (pela minha qualificação e carta de recomendação), Marilyn Vihman (pelo apoio, dicas e atenção), Marina Nespor (pelas dicas e humildade) e Waldemar Ferreira Neto (pela minha qualificação e conversas descontraídas).

A todos os diretores, professores, funcionários, pais e alunos das creches por onde passei por todo carinho e amparo.

Agradeço ao Fidel Beraldi pelo trabalho de estatística realizado para esta pesquisa. Por fim, agradeço à CAPES pela bolsa concedida. 


\section{RESUMO}

O objeto específico desta pesquisa de mestrado é investigar qual o modelo prosódico inicial na aquisição do português brasileiro (doravante PB) e a possível influência da metodologia utilizada nos resultados. Partindo da pressuposição de que há uma gramática inicial, dada pela gramática universal (CHOMSKY, 1981), autores que lidam com línguas germânicas afirmam que o troqueu é o modelo prosódico default na aquisição (cf. GERKEN, 1994; FIKKERT, 1994), e o mesmo é defendido por estudos que lidam com outras famílias lingüísticas (cf. ADAM \& BAT-EL, 2007 para o hebraico; PRIETO, 2005 para o catalão, por exemplo). No entanto, os dados infantis do PB trazem complicações para a suposta tendência trocaica universal, pois estudos observacionais (naturalísticos) encontram uma tendência iâmbica (SANTOS, 2001, 2007; BONILHA, 2004; BAIA, 2006).

Apesar de haver no cenário da literatura brasileira debates e estudos recentes a respeito do modelo prosódico inicial (cf. RAPP, 1994; BONILHA, 2004; SANTOS, 2006, 2007), algumas questões ainda permanecem. A maior parte desses trabalhos é composta por estudos observacionais e não experimentais, o contrário do que normalmente acontece na literatura estrangeira. O único estudo experimental no PB conhecido até então é o de Rapp (1994), o qual afirma haver uma tendência trocaica nos dados iniciais do PB. Enquanto a autora aponta uma tendência trocaica, nenhum estudo observacional a confirma; ao contrário, estes estudos levantam indícios a favor de uma tendência iâmbica inicial (BONILHA, 2004; SANTOS, 2006, 2007; BAIA, 2006). Logo a pesquisa aqui conduzida visa verificar se há influência da metodologia empregada nos resultados apresentados pela literatura brasilera. Para isso, nesta dissertação, são utilizadas as duas metodologias na análise dos dados (a experimental e a observacional): no estudo experimental, são analisados dados de 42 crianças na faixa etária de 1;5 - 3;0 anos, e no estudo observacional, são analisados dados de uma criança (LUI) na mesma faixa etária do estudo experimental.

Os resultados obtidos por meio dos dois estudos realizados nesta pesquisa corroboram o que é afirmado pelo estudo experimental de Rapp (1994) e pelos estudos observacionais (SANTOS, 2006, 2007; BONILHA, 2004; BAIA, 2006). Dessa maneira, os resultados apresentam a mesma discrepância a respeito da tendência prosódica inicial presente na comparação entre os estudos que adotam diferentes métodos. No entanto, foi encontrada uma explicação para o que ocasiona tal discrepância. Notou-se que os iambos diminuem se o léxico particular e os verbos são excluídos dos dados. Sem o léxico particular e verbos, há uma predominância de SW em DES e DEX. Dessa maneira, a diferença entre os resultados do estudo experimental e dos estudos observacionais está relacionada com a metodologia empregada e, particularmente, com o inventário lexical e classe gramatical considerados na análise.

Por fim, acredita-se que o estudo que desconsidere todos os tipos de produções infantis não pode afirmar, categoricamente, uma outra tendência inicial. Por essa razão, afirma-se que o PB apresenta uma tendência iâmbica inicial, tendência defendida pelos estudos observacionais (BAIA, 2006; SANTOS, 2007) que lidam com a produção lexical infantil na sua totalidade, embora não se trate de uma tendência forte e seja apenas uma tendência aparente de acordo com os resultados estatísticos deste estudo.

Palavras-chave: acento, prosódia, modelo prosódico inicial, aquisição de linguagem. 


\begin{abstract}
This research aims at investigating the initial prosodic template in the acquisition of Brazilian Portuguese (henceforth BP) and the influence of the methodology on the results presented by Brazilian literature so far.

Following the view that there is an initial grammar (universal grammar) (CHOMSKY, 1981), authors who deal with Germanic languages state that the trochee is the initial prosodic template (see GERKEN, 1994; FIKKERT, 1994), and the same is claimed by studies that deal with languages from other families (see ADAM \& BAT-EL, 2007 about Hebrew acquisition; PRIETO, 2005 about Catalan acquisition, for example). However, data from Brazilian children bring complications for this trochaic bias when show the results of observational studies (naturalistic studies), which point out an iambic bias instead (SANTOS, 2001, 2007; BONILHA, 2004; BAIA, 2006).

Besides the discussions and recent studies about the prosodic initial template (see RAPP, 1994; BONILHA, 2004; SANTOS, 2006, 2007) that have been conducted by Brazilian researchers, some questions still remain. Most of these studies on BP acquisition are observational and they assert that there is an initial iambic bias, whereas there is only one experimental study (RAPP, 1994), which states that there is a trochaic bias. Therefore, the research conducted here aims at analyzing the influence of the employed methodology on the results. To make it possible, two methodologies are used in the analysis of data (the experimental and observational): in the experimental study, we analyze data of 42 children at age 1;5 - 3;0 years old, and in the observational study, we analyze data of a child (LUI) who is the same age of experimental group.

The results corroborate what has been stated by the experimental study (RAPP, 1994) and by the observational ones (Santos, 2006, 2007; BONILHA, 2004; BAIA, 2006) because it was found the same discrepancy showed by these studies. But there is an explanation. It was noted that the number of iambs decreases if the particular lexicon (familiar words and lexical creations) and verbs are kept out of the data. Without this sort of words, there is a predominance of SW in DES and DEX. Thus, the difference between the results of the experimental study and observational ones is due to the employed methodology, particularly, due to the lexical inventory considered in the analysis.

Finally, we believe that if the study does not take into account all types of children's productions it can not state, categorically, any initial prosodic bias. Therefore, this study agrees with what has been stated by observational studies, i.e. BP early data show an iambic bias (BAIA, 2006; SANTOS, 2007), also, this was observed in the analysis of DES. However, the statistical results did not show any significant predominance of a specific prosodic template. Santos (2007) claims that there is not a universal prosodic template. For that reason we find a trochaic bias in Germanic languages and an iambic bias in BP.
\end{abstract}

Keywords: stress, prosody, initial prosodic template, language acquisition 
Don't be too timid and squeamish about your actions. All life is an experiment. The more experiments you make the

better.

Sometimes a scream is better than a thesis.

Our knowledge is the amassed thought and experience of innumerable minds.

Ralph Waldo Emerson 


\section{ÍNDICE}

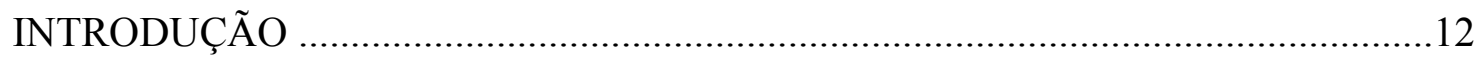

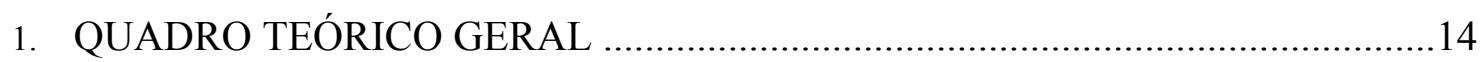

1.1 Princípios e parâmetros …………………………………………………………....

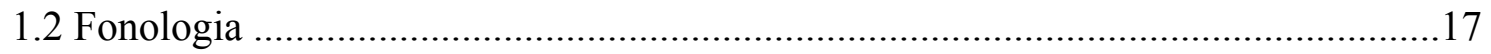

1.2.1 Estudos de prosódia

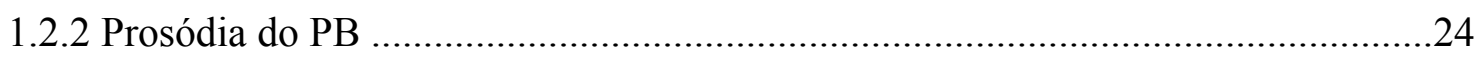

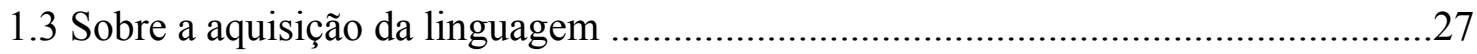

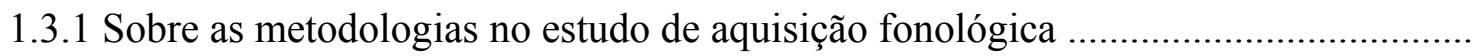

1.3.1.1 Sobre o léxico contemplado em cada método ...................................................32

2. ESTUDOS PRÉVIOS SOBRE O MODELO PROSÓDICO INICIAL ....................39

2.1 Nas línguas germânicas - o início da discussão

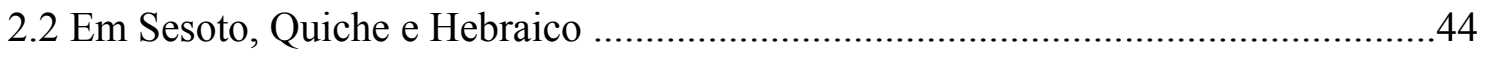

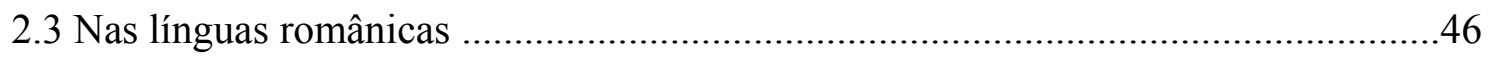

2.4 Há uma tendência prosódica universal? ................................................................56

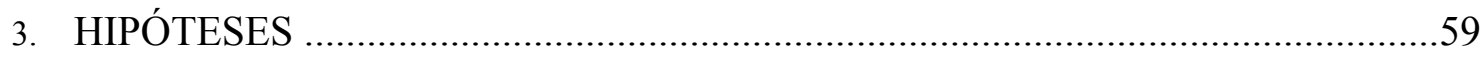

4. DADOS EXPERIMENTAIS (DEX) …………..................................................61

4.1 Metodologia

4.1.1 Seleção do léxico a ser testado .......................................................................63

4.1.2 Descrição do experimento ................................................................................65

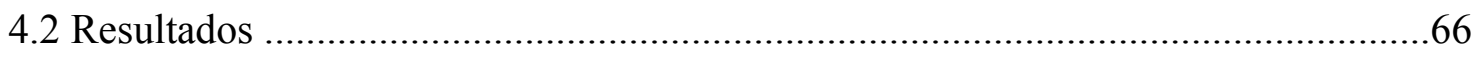

4.2.1 Produções pelo tamanho da palavra …………....................................................71

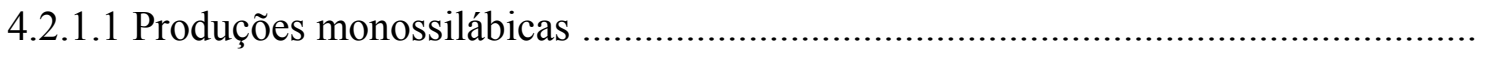




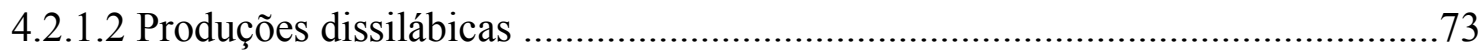

4.2.1.3 Produções trissilábicas ..................................................................................76

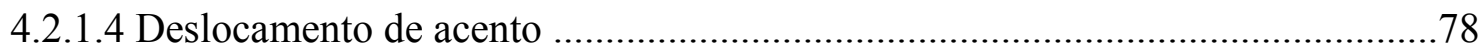

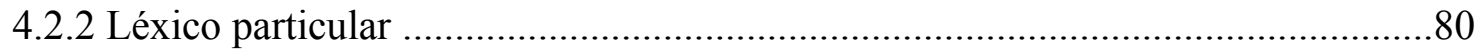

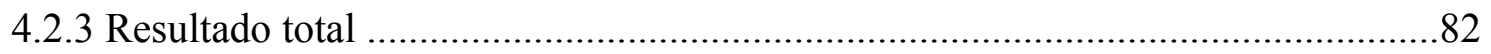

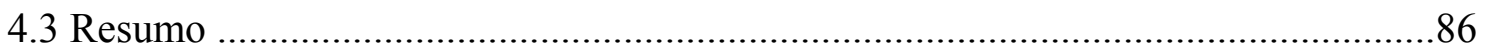

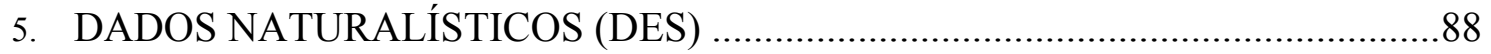

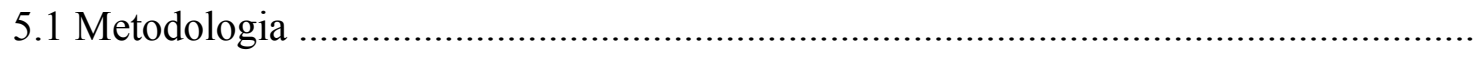

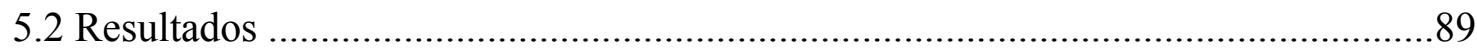

5.2.1 Produções pelo tamanho da palavra .....................................................................90

5.2.2 Resultados: DES-nomes ……………………….............................................

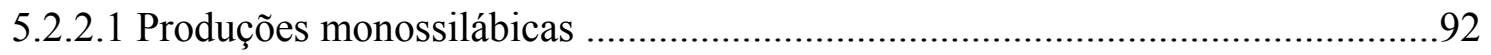

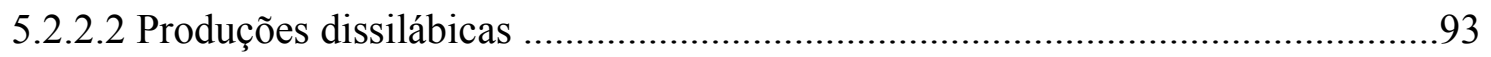

5.2.2.3 Produções trissilábicas .......................................................................................96

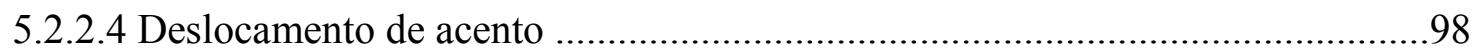

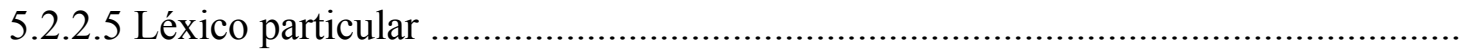

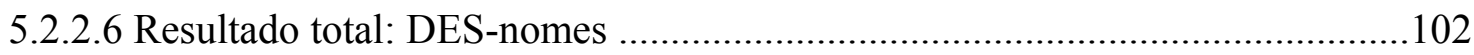

5.2.3 Resultados: o papel dos verbos ......................................................................106

5.2.4 Resultados: nomes com verbos (sem léxico particular) …………......................111

5.2.5 Resultados: nomes com verbos (total) ………….........................................113

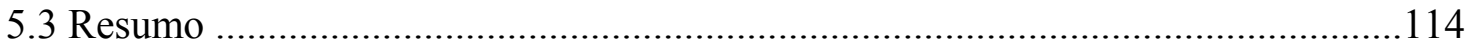

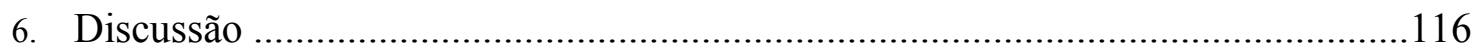

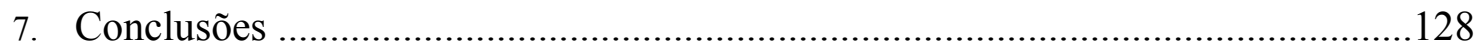

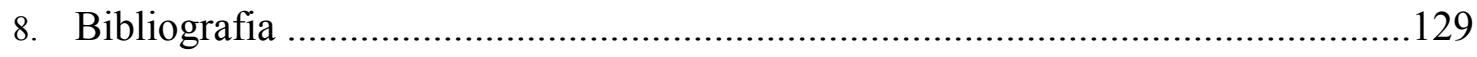


9. Anexos

9.1 Anexo 1: desenhos utilizados em DEX

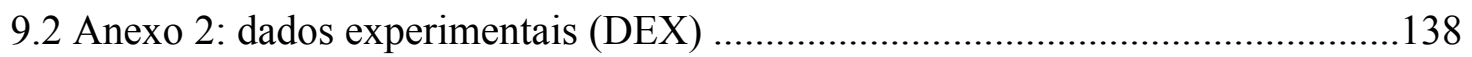

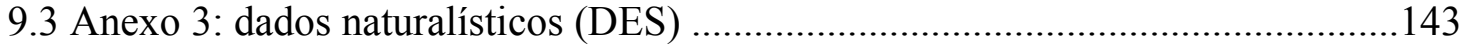




\section{INTRODUÇÃO}

O objeto desta pesquisa de mestrado é investigar qual a forma prosódica inicial na aquisição do português brasileiro (doravante PB) e a possível influência da metodologia utilizada nos resultados.

Partindo da pressuposição de que há uma gramática inicial, dada pela gramática universal (CHOMSKY, 1981), autores que lidam com línguas germânicas afirmam que o troqueu é o modelo prosódico default na aquisição (cf. GERKEN, 1994; FIKKERT, 1994). Além dos estudos com línguas germânicas, que defendem o troqueu como pé inicial, há estudos que lidam com línguas de outras famílias lingüísticas e que corroboram tal afirmação (cf. ADAM \& BAT-EL para o hebraico, 2007, PRIETO, 2005 para o catalão, por exemplo). No entanto, os dados infantis do PB trazem complicações para a suposta tendência trocaica universal, pois estudos observacionais encontram uma tendência iâmbica (SANTOS, 2001, 2007; BONILHA, 2004; BAIA, 2006) que, segundo Santos (2007), pode ser melhor compreendida se for assumido que o parâmetro do núcleo na construção de pés não tem um valor default. Por essa razão, segundo a autora, encontra-se uma tendência iâmbica nos dados infantis do PB, enquanto que o do holandês, por exemplo, apresenta uma tendência trocaica (FIKKERT, 1994).

Apesar de haver no cenário da literatura brasileira debates e estudos recentes a respeito desse tema (cf. RAPP, 1994; BONILHA, 2004; SANTOS, 2006, 2007), algumas questões ainda permanecem. A maior parte desses trabalhos é composta por estudos observacionais e não experimentais, o contrário do que normalmente acontece na literatura estrangeira. O único estudo experimental no PB conhecido até então é o de Rapp (1994), o qual afirma haver uma tendência trocaica nos dados iniciais do PB. Enquanto a autora 
aponta uma tendência trocaica, nenhum estudo naturalístico a confirma; ao contrário, estes estudos levantam indícios a favor de uma tendência iâmbica inicial (BONILHA, 2004; SANTOS, 2006, 2007; BAIA, 2006). Logo a pesquisa aqui conduzida visa verificar se há influência da metodologia empregada nos resultados apresentados pela literatura brasileira. Para isso, nesta dissertação, são utilizadas as duas metodologias na análise dos dados (a experimental e a observacional): no estudo experimental, são analisados dados controlados de 42 crianças na faixa etária de 1;5 - 3;0 anos, e no estudo observacional, são analisados dados de uma criança (LUI) na mesma faixa etária do estudo experimental.

No que se refere à abordagem teórica seguida, esta pesquisa assume a Teoria de Princípios e Parâmetros (CHOMSKY, 1981), uma versão da teoria da gramática universal (GU) que foi desenvolvida para explicar aspectos universais e específicos nas gramáticas particulares. É usada também a adaptação realizada por Dresher \& Kaye (1990) para a aquisição do acento e o inventário universal de pés proposto por Hayes (1995), o qual é utilizado na discussão a respeito da questão tendência trocaica versus iâmbica.

Esta dissertação está organizada da seguinte forma: no capítulo 1, é apresentado quadro teórico geral no que se refere aos estudos de prosódia e aquisição relacionados com o objeto desta pesquisa; no capítulo 2, são apresentados os estudos prévios sobre o formato prosódico inicial; no capítulo 3 são apresentadas as hipóteses que serão perseguidas no decorrer da análise; nos capítulos 4 e 5, são apresentados os resultados da análise dos dados aqui considerados (naturalísticos e experimentais); no capítulo 6, é apresentada a discussão dos resultados; e no capítulo 7, as considerações gerais. 


\section{QUADRO TEÓRICO GERAL}

\subsection{Princípios e parâmetros}

A teoria gerativa surgiu no contexto do que é freqüentemente chamado de "a revolução cognitiva" dos anos 50, assumindo que todos os seres humanos nascem equipados com uma faculdade da linguagem, um componente na mente/cérebro especificamente dedicado à linguagem. É uma teoria inatista ${ }^{1}$ porque parte do pressuposto de que o ser humano possui uma dotação genética que o capacita a adquirir e usar uma língua. Por essa razão, a linguagem aparece sem precisar de muitos esforços, tanto que Chomsky (1998) compara o processo de aquisição de língua com o crescimento dos órgãos do nosso corpo: “(...) é algo que acontece com a criança e não algo que a criança faz (...) em suas propriedades essenciais, as línguas são moldadas na mesma forma” (CHOMSKY, 1998:23). Pensando em nature vs nurture (natureza vs educação), pode-se dizer que a teoria gerativista focaliza a sua atenção no que é dado pela natureza do ser humano.

Esta pesquisa de mestrado adota o segundo momento da Teoria Gerativa. No primeiro, a "Teoria Padrão" (CHOMSKY, 1965), o estado inicial de aquisição era responsável por definir possíveis regras e a seleção do sistema ideal de regras, que compõem a Gramática Universal (GU). Chomsky propõe, inicialmente, um dispositivo de aquisição da linguagem (DAL), que é alimentado pelos dados lingüísticos primários e tem como produto final uma gramática devido à entrada e saída dos dados específicos. Porém,

\footnotetext{
${ }^{1}$ Essa visão inatista, presente na teoria gerativa, tem suas origens no racionalismo filosófico, o qual se deu com as idéias do filósofo René Descartes no século XVII contra as dos empiricistas. O racionalismo cartesiano, influenciado por algumas idéias de Platão, designa-se por inatista pelo fato de considerar que o indivíduo nasce com idéias inatas que ele considera sementes de verdade (JAPIASSÚ \& MARCONDES, 1996).
} 
este primeiro momento da teoria baseado em regras não dispunha de uma explicação geral a respeito da variação e similaridades existentes entre as línguas, a não ser a que se baseava na escolha das regras. No segundo momento, “A Teoria dos Princípios e Parâmetros”, Chomsky (1981), no intuito de abordar variações existentes entre as línguas, afirma que a GU é formada por princípios - 'leis’ que não variam e que se aplicam da mesma forma em todas as línguas, e parâmetros - 'leis' cujos valores variam dentre as línguas e que dão origem tanto às diferenças entre elas como também à mudança de uma língua. Os parâmetros, além de explicarem as diferenças óbvias entre as gramáticas de diferentes línguas, permitem explicar também as diferenças presentes no desenvolvimento da linguagem (MEISEL, 1997).

No âmbito dessa proposta, no que se refere à aquisição da língua materna, assumese que os parâmetros têm um valor inicial (default), porém se na gramática alvo o valor do parâmetro for diferente, deve haver a modificação do valor de default para a realidade presente na língua. No entanto, o valor default não permanece por muito tempo por causa da rapidez com a qual a criança adquire sua língua, e.g. com cerca de quatro anos, a criança já domina grande parte do sistema fonológico da sua língua, além da sintaxe, morfologia e semântica. A fixação do parâmetro de acordo com a língua-alvo levará à eliminação da opção que, dependendo da língua, pode ser a incorreta, i.e. enquanto a criança ainda não fixou o parâmetro, sua produção estará de acordo com a gramática default. Quando o que está na gramática default coincide com o que está presente na língua-alvo, o parâmetro não é modificado. A literatura aquisicionista, que lida com modelo prosódico inicial, tem cogitado a existência de um valor default no que se refere ao valor do núcleo do pé métrico. Por causa desse valor default, a proeminência seria assinalada à esquerda, criando um pé trocaico (cf. GERKEN, 1994, FIKKERT, 1994). Dessa maneira, em línguas que 
apresentam o troqueu como pé básico, não haveria alteração da gramática default para a alvo (e.g. no inglês), mas em línguas como o francês (núcleo do pé à direita) a fixação do parâmetro ocasionaria uma mudança da gramática default para a gramática alvo.

No entanto, uma outra proposta, a de Santos (2007), afirma que não há um valor default no que se refere ao núcleo do pé. Segundo a autora, este parâmetro não vem marcado e não haveria, inicialmente, uma tendência prosódica predominante por causa de uma gramática inicial. Dessa maneira, apagamento silábico, adição de segmentos ou deslocamento de acento não favoreciam um modelo prosódico default, e o predomínio de iambos ocorreria porque como não há um valor inicial, a criança tem que marcar o parâmetro de acordo com a língua dela para a produção de dissílabos; em português marcase iambo e em inglês/holandês marca-se troqueu, por exemplo.

Independentemente de se assumir uma proposta de que os parâmetros já tenham um valor default, ou de que ao menos alguns parâmetros não têm um valor inicial, uma questão se coloca a respeito da marcação dos valores paramétricos: por que a fixação dos parâmetros não ocorre assim que a evidência positiva surge no input da criança? Há duas hipóteses que tentam responder a esta questão, a maturacional e a continuísta. Segundo Meisel (1997), a primeira, a hipótese maturacional, assume que os princípios da GU surgem segundo um cronograma maturacional especificado de modo inato e relacionado com a própria maturação física, no qual certos princípios, que não se encontram disponíveis em um certo momento, estarão em um momento posterior; e de acordo com essa hipótese a gramática inicial pode apresentar propriedades únicas, diferentes da gramática adulta. A segunda hipótese, a continuísta, assume que o cronograma do desenvolvimento não se remete às causas físicas e, segundo Meisel (1997), essa hipótese parte do pressuposto de que a gramática inicial já começa formada pelas mesmas categorias e princípios de uma 
gramática adulta. Dessa maneira, todos os parâmetros estão disponíveis para serem fixados imediatamente, e se isso não ocorre é devido a alguma dificuldade na sua determinação que está relacionada com a experienciação, pois a transição entre os estágios é determinada pelo reconhecimento, por parte da criança, de dados desencadeadores que estruturam a gramática (SANTOS, 1995). Os principais problemas presentes nesta hipótese residem em determinar quais são e como funcionam os elementos a serem desencadeados.

Nesta dissertação, assume-se a hipótese maturacional, pois, partindo da comparação feita por Chomsky (1998) a respeito da semelhança entre o surgimento da língua e o crescimento dos órgãos do corpo, é plausível pensar que o desenvolvimento da linguagem segue o desenvolvimento de outras funções do corpo e, por essa razão, pode-se supor que, a princípio, nem todos os elementos gramaticais estejam presentes de acordo com a forma alvo.

\subsection{Fonologia}

\subsubsection{Estudos de prosódia}

Segundo a sua etimologia, prosódia, termo que vem do grego $\pi \rho 0 \sigma \omega \delta i \alpha$ ( $\pi \rho \circ \sigma-$ junto / $\omega \delta 1 \alpha-$ canto), significa melodia que acompanha o discurso e, na língua grega, mais precisamente, o acento melódico que o caracteriza. Segundo Pereira (1992), por volta de 300 d.C, na cultura grega, passaram a ser considerados "prosódias" o acento melódico, a aspiração e a duração. No entanto, foi no Renascimento que a prosódia passou a ser vista como um ramo científico por meio do acréscimo dos estudos de versificação. Desde então, 
ela tem sido alvo de estudos nas ciências da linguagem, como, por exemplo, o conduzido nesta dissertação.

Os estudos de prosódia foram incorporados na teoria gerativa em meados dos anos 70 com os trabalhos de Liberman (1974) e Liberman \& Prince (1977) sobre fonologia métrica. Isso porque antes da proposta métrica a teoria gerativa não dispunha de uma teoria específica para estudos de ritmo ou acento, pois era guiada no estudo fonológico por assunções feitas na obra SPE (Sound Pattern of English) de Chomsky \& Halle (1968). Nesta obra não apenas o pé, mas todo o tipo de unidades prosódicas (inclusive a sílaba) está ausente, sendo o acento a única exceção, reduzido, no entanto, ao status de traço distintivo atribuído às vogais.

Como não é o intuito desta pesquisa apresentar um panorama geral dos estudos de prosódia, cabe ressaltar os pontos teóricos que ajudam no entendimento acerca dos padrões prosódicos na fala infantil inicial. O primeiro passo é dado por meio da apresentação da origem dos termos utilizados pela teoria métrica, termos que provêm da música e dos estudos de versificação poética. Um dos conceitos fundamentais da fonologia métrica é o conceito do pé $(\Sigma)$ que, segundo Massini-Cagliari (1999:113), tem sua origem na poética clássica, quando era usado tanto em análises literárias de poemas quanto no estabelecimento de princípios de construção de versos (teorias de metrificação). Alguns exemplos de pés da métrica latina: 
Nome do pé

Espondeu

Troqueu (ou coreu)

Dátilo

Iambo (ou jambo)

Pirríquio

Anapesto (ou antidátilo)

Tríbaco

Molosso

Coriambo (troqueu + iambo)

Proceleusmático

$$
\text { tipo }^{2}
$$

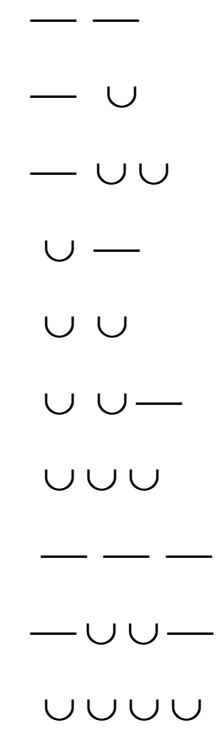

Em geral, assume-se que o conceito de pé está ligado ao próprio movimento do pé humano, para cima e para baixo, e também à noção de compasso musical. Tal comparação ainda permanece nas explicações didáticas sobre fonologia métrica de autores como Fudge (1999), que compara o downbeat do compasso musical (movimento com a batuta que marca o início do compasso) à sílaba acentuada que os ouvintes usam para dividir um enunciado em partes menores.

No que se refere à teoria paramétrica, são duas as principais propostas acerca dos padrões métricos relacionados com a acentuação: i) a de Dresher \& Kaye (1990), que descreve os parâmetros que precisam ser assinalados na aquisição do padrão prosódico lexical de uma língua, isto é, os autores apresentam o pé como resultado de uma combinação dos parâmetros marcados; ii) a de Hayes (1995), que propõe um inventário finito de pés, o qual foi construído a partir da análise métrica de diversas línguas. A diferença entre as duas propostas é que enquanto Dresher \& Kaye apresentam os

${ }^{2}$ — indica sílaba longa e $\cup$ indica sílaba breve. 
parâmetros que operam na derivação do acento, Hayes propõe um inventário universal de pés que é um subconjunto dos possíveis pés que podem surgir após a fixação dos parâmetros.

Dresher \& Kaye (1990) direcionam o olhar para a questão da aquisição de um subsistema da estrutura fonológica, a saber, o sistema acentual, utilizando como perspectiva teórica a Teoria Princípios e Parâmetros (CHOMSKY, 1981). Na proposta dos autores, são apresentados os seguintes parâmetros responsáveis pela determinação do acento:

\section{Os parâmetros métricos de Dresher \& Kaye $(1990)^{3}$}

P1: Os pés são [binários/ilimitados]

P2: Os pés são construídos da [esquerda/direita]

P3: Os pés são fortes no lado [esquerdo/direito]

P4: Os pés são sensíveis à quantidade silábica (SQ) [sim/não]

P5: Os pés são SQ na [rima/núcleo]

Apesar dos demais parâmetros serem cruciais para a derivação do acento, nesta pesquisa, pela derivação não ser o foco da discussão, o parâmetro sob investigação é o P3, o qual está relacionado com a marcação do núcleo do pé. Segundo os autores, cada parâmetro (ou em alguns casos, um grupo de parâmetros) está associado com uma pista específica presente nos dados, com a qual o aprendiz entra em contato. Tal pista, segundo Dresher \& Kaye (1990), serve como um dispositivo para a fixação dos parâmetros e pode estar, no caso de P3, presente na freqüência com a qual um tipo de acento é repetido, i.e. mais palavras com acento marcado à direita ou à esquerda.

\footnotetext{
${ }^{3}$ Alguns parâmetros levantados pelos autores não foram inseridos nesta discussão, pois não são considerados relevantes para o escopo desta pesquisa.
} 
Como será discutido na próxima seção, alguns estudos sobre o modelo prosódico inicial defendem que o P3 venha com um valor default (GERKEN, 1994; FIKKERT, 1994; DEMUTH, 1996), o qual estaria marcado no lado esquerdo do pé, ocasionando, assim, uma tendência trocaica nos dados iniciais. Uma outra proposta é a de que P3 não viria com um valor marcado inicialmente (SANTOS, 2007); dessa maneira, não haveria, no início, a predominância majoritária de troqueus no PB.

A proposta de Hayes (1995), diferentemente da de Dresher \& Kaye (1990), não está preocupada com o processo de aquisição do acento, mas em apresentar um inventário que dê conta dos pés presentes nas línguas em geral. O autor afirma que os parâmetros que estabelecem o ritmo das línguas, os quais coincidem com os apresentados por Dresher \& Kaye (1990), são responsáveis pela recorrência de um inventário de estruturas métricas básicas. O cruzamento das possibilidades de escolhas de valor dos vários parâmetros que regem o acento das línguas produz um inventário finito de pés, que dariam conta da descrição de todas as línguas do mundo. O inventário de pés proposto por Hayes é apresentado a seguir:
a. Troqueu Silábico
$(\mathrm{S} \mathrm{W})^{4}$
$\sigma \sigma$
b. Troqueu Moraico
(S W) ou (S)
c. Iambo
$\cup \cup-$
(W S) ou (S)
$\cup \sigma \quad-$

\footnotetext{
${ }^{4} \sigma$ : sílaba / S: strong - sílaba forte / W: weak -sílaba leve.
} 
i. Troqueu Silábico: não há diferenças entre sílabas leves e pesadas para a constituição dos pés; os sistemas são insensíveis ao peso silábico, com constituintes binários à esquerda;

ii. Troqueu Moraico: há diferenças entre sílabas leves e pesadas; os sistemas são sensíveis ao peso silábico, com constituintes binários de cabeça à esquerda;

iii. Iambo: há diferenças entre sílabas leves e pesadas; os sistemas são sensíveis ao peso silábico, com constituintes binários de cabeça à direita, ao contrário do troqueu moraico.

Como se pode observar, os pés propostos por Hayes (1995) são, no máximo, dissilábicos. Na proposta do autor, a língua faz uma opção quanto à importância da quantidade silábica quando escolhe o tipo de pé. Se a língua for sensível ao peso silábico, trata-se de uma língua que opta pelo troqueu moraico ou iambo, caso contrário, pelo troqueu silábico. Ademais, este inventário apresenta dois tipos de pés trocaicos, o silábico e o moraico, e apenas uma possibilidade de pé iâmbico. Nota-se, assim, que a inovação teórica na proposta do autor está na assimetria presente no inventário de pés, a qual tem uma base rítmica. Segundo o autor, há uma correlação entre tipo rítmico e duração, pois línguas com ritmo trocaico são caracterizadas pela duração equivalente entre os elementos do pé, i.e. o troqueu é balanceado no que se refere à quantidade silábica porque contém duas sílabas leves ou peso indiscriminado, enquanto que um troqueu sem esse 'balanceamento' seria marginal; em línguas iâmbicas, o quadro é contrário, pois o que ocorre é uma duração diferenciada entre os elementos do pé porque um pé iâmbico tende a ter uma sílaba leve seguida de uma sílaba pesada. 
Hayes relaciona essa assimetria presente no inventário de pés a um universal perceptual proposto por dois psicolingüistas (BOLTON, 1984, WOODROW, 1909), o qual estabelece que a percepção de grupos rítmicos depende do parâmetro acústico utilizado na diferenciação, a saber a intensidade ou duração. Dessa maneira, a seqüência de elementos que alternam em duração tende a ser percebida como iâmbica, enquanto que a seqüência de elementos que alternam em intensidade tende a ser percebida como trocaica.

O autor apresenta, então, uma motivação baseada em características acústicas para princípios internos do sistema lingüístico que derivam da lei de boa formação da estrutura rítmica:

\section{Lei Iâmbico-Trocaica}

a. Elementos que contrastam em intensidade naturalmente formam agrupamentos com proeminência inicial;

b. Elementos que contrastam em duração naturalmente formam agrupamentos com proeminência final.

(HAYES, 1995:80)

O interessante da proposta de Hayes é que, ao propor esse inventário, o autor estabelece a dicotomia iambo versus troqueu, isto é, o núcleo do pé, que carrega acento primário ou secundário da palavra, pode estar marcado à direita (iambo) ou esquerda (troqueu). 


\subsection{Prosódia do PB}

Segundo Mattoso Câmara (1975), o acento do português é livre dentro dos limites compreendidos entre a última e antepenúltima sílaba da palavra. Cintra (1997) confirma o que foi observado por Mattoso Câmara e afirma que:

“(...) em vocábulos isolados o acento principal (dito tônico) pode incidir sobre qualquer das três últimas sílabas (...) Intuitivamente sabe-se que predominam os vocábulos paroxítonos."

(CINTRA, 1997:82)

Esse conhecimento intuitivo reflete-se, segundo Cintra, em parte adequadamente, nos critérios de acentuação gráfica em vigor. O autor analisa a distribuição de padrões acentuais com base em três textos: Clemente (1985: 1068 vocábulos), Menezes (1993: 1124 vocábulos) e Saramago (1993: 806 vocábulos). A unidade considerada é o vocábulo gráfico, delimitado por espaços em branco e/ou sinais de pontuação, ou seja, a palavra lexical. Além disso, o autor considerou para a sua análise vocábulos com no máximo sete sílabas. Quanto ao padrão de acentuação foi encontrado o seguinte resultado:

\begin{tabular}{|c|c|c|c|}
\hline Padrão de acentuação & No. & Texto total & Voc. Acent. \\
\hline Quarta última sílaba & 2 & $1 \%$ & $0 \%$ \\
\hline Proparoxítonos & 130 & $4 \%$ & $7 \%$ \\
\hline Paroxítonos & $\mathbf{1 2 4 8}$ & $\mathbf{4 2 \%}$ & $\mathbf{6 3 \%}$ \\
\hline Oxítonos & 359 & $12 \%$ & $18 \%$ \\
\hline Monossílabos tônicos & 248 & $8 \%$ & $12 \%$ \\
\hline Monossílabos átonos & 942 & $31 \%$ & \multirow{2}{|}{} \\
\cline { 1 - 3 } Dissílabos átonos & 69 & $2 \%$ & \\
\cline { 1 - 2 } & &
\end{tabular}

Quadro 1: Distribuição dos padrões acentuais no português (Cintra 1997) 
Observando os resultados levantados por Cintra, nota-se que há um maior número de troqueus $(63 \%)$ em português. Essa predominância de troqueus também é encontrada por Albano (2001) em um estudo sobre as entradas lexicais no dicionário, e por Consoni (2006) em um estudo sobre a percepção de trissílabos com a última sílaba apagada. Consoni, após recortar a sílaba final de trissílabos com as duas sílabas iniciais idênticas, pediu que seus informantes dissessem qual palavra havia sofrido apagamento das três opções na ficha (fábrica, fabrica, fabricar $)^{5}$. Segundo a autora, a escolha dos informantes foi norteada pelo padrão paroxítono do português, pois prevaleceu a primeira opção na escolha dos informantes (fábrica) que cria um troqueu (fá.bri), gerando, assim, erros na escolha em direção ao padrão paroxítono.

Sabe-se que a predominância de vocábulos paroxítonos no PB é uma herança do latim (FERREIRA NETTO, 2001) e que, por essa razão, o status das oxítonas no PB é um dos fenômenos prosódicos lexicais mais interessantes na língua por não poder ser explicado como advindo do latim. Um estudo que busca explicar a origem das oxítonas é o de Pereira (2007), o qual atribui a emergência de oxítonas nas línguas românicas, em geral, à perda do valor fonológico da quantidade silábica, ocasionada por processos de síncope e apócope sofridos pelas vogais átonas (uagare $>$ vagar, sonare $>$ soar $>$, aviolu $>$ avoo $>$ avô $)^{6}$.

Tais alterações fizeram com que emergissem as oxítonas nas línguas românicas, contrariamente ao que ocorria em latim, língua na qual os polissílabos podiam ser paroxítonos ou proparoxítonos. Uma outra explicação elaborada por Agostinho \& Araújo

\footnotetext{
${ }^{5}$ A sílaba sublinhada foi apagada para o experimento.

${ }^{6}$ Exemplos retirados de Coutinho (1969).
} 
(2007) afirma que a maioria das palavras oxítonas, em português, é empréstimo lexical do latim, tupi, francês, árabe e iorubá.

Além dos estudos que tratam de prosódia lexical analisando os dados na sua superfície, há as propostas de algoritmo de acentuação para o $\mathrm{PB}$, que propõem o processo de derivação do acento. Essas propostas assumem como perspectiva teórica, em geral, a fonologia métrica, como os estudos Bisol (1992) e Massini-Cagliari (1995). As autoras afirmam que o PB é uma língua trocaica moraica, ou seja, sensível à quantidade silábica, e que o domínio de aplicação da regra (ou marcação paramétrica) é a palavra lexical. Uma outra proposta que lida com derivação de acento é a de Lee (1995), que não pesquisa no âmbito da fonologia métrica, mas sim no da fonologia lexical. Segundo o autor, o PB não é sensível à quantidade silábica, comporta tanto iambos quanto troqueus, e o domínio de aplicação de regra é o radical para os nomes e a palavra lexical para os verbos.

A seguir, são retomados os parâmetros propostos por Dresher \& Kaye (1990) e adaptados à proposta dos autores:

\begin{tabular}{|l|c|c|}
\hline $\begin{array}{c}\text { Parâmetros da teoria métrica } \\
\text { (Dresher \& Kaye 1990) }\end{array}$ & $\begin{array}{c}\text { Bisol (1992)/ } \\
\text { Massini-Cagliari (1995) }\end{array}$ & $\begin{array}{c}\text { Lee (1995) } \\
\text { (não-marcados) }\end{array}$ \\
\hline P1: Os pés são & [binário] & [binário] \\
\hline P2: Os pés são construídos da & [direita] & [direita] \\
\hline P3: Os pés são fortes no lado & [esquerdo] & $\begin{array}{c}\text { [direito] - nomes } \\
\text { [esquerdo] - verbos }\end{array}$ \\
\hline $\begin{array}{l}\text { P4: Os pés são sensíveis à } \\
\text { quantidade silábica (SQ) }\end{array}$ & [sim] & [não] \\
\hline P5: Os pés são SQ na & [rima] & - \\
\hline
\end{tabular}


Nota-se, dessa maneira, que, exceto pela proposta de Lee, as demais propostas vão assumir que o pé básico do PB é o troqueu, ou, no caso dos estudos puramente prosódicolexicais, que os paroxítonos são predominantes da língua.

\subsection{Sobre a aquisição da linguagem: questões metodológicas}

Nesta seção, são apresentadas as características das diferentes metodologias no estudo de produção na aquisição da linguagem e o léxico infantil.

\subsubsection{Sobre as metodologias no estudo de aquisição fonológica}

Como foi exposto na introdução desta dissertação e será retomado nas próximas seções, uma das principais questões que esta pesquisa pretende responder está relacionada com a discrepância entre os resultados apresentados pelos trabalhos que lidam com dados naturalísticos e os que lidam com dados experimentais. O primeiro grupo apresenta resultados que vão a favor de uma tendência iâmbica inicial na aquisição do PB (BONILHA, 2004; SANTOS, 2006, 2007; BAIA, 2006), enquanto que o segundo apresenta resultados que confirmam a tendência trocaica (RAPP, 1994), defendida como universal por muitos autores (ALLEN \& HAWKINS, 1980; GERKEN, 1994; FIKKERT, 1994; ARCHIBALD, 1995; ADAM \& BAT-EL, 2007). No intuito de esclarecer tal discrepância, esta pesquisa apresenta um estudo utilizando as duas metodologias a fim de se realizar uma

comparação entre os resultados e averiguar o que pode estar influenciando a discordância entre os resultados do PB. 
Se a metodologia pode afetar os resultados, é importante, antes de apresentá-los, fazer uma descrição das duas metodologias presentes neste estudo (observacional e experimental). Sabe-se que diferentes métodos são adotados para cada tipo de estudo (percepção, compreensão ${ }^{7}$ e produção da fala); no entanto, esta pesquisa lida apenas com experimento de produção.

O método observacional foi o primeiro método de coleta de dados da fala infantil, e era realizado por meio de diários mantidos por psicólogos e lingüistas que eram, na sua maioria, pais. No entanto, por volta de 1960, o método apenas escrito foi, gradualmente, substituído por gravações de áudio da produção da criança. O pesquisador que trabalha com método observacional não precisa designar um estímulo específico para o participante, pois tanto a produção quanto a compreensão da linguagem ocorrem em uma situação normal de interação entre o falante e ouvinte. Dessa maneira, grava-se e depois os dados relevantes são procurados e selecionados.

Apesar de esse método lidar com a fala espontânea, certos cuidados precisam ser tomados, tais como: selecionar o número de crianças, estabelecer quais crianças podem participar do estudo e como transcrever as sessões. Além disso, na análise de dados naturalísticos, deve ser estabelecido um critério no recorte dos dados relacionado com o tipo de produção a ser considerada e categorizada, por exemplo, se serão considerados apenas os dados de produção espontânea ou de imitação também.

Alguns aspectos positivos desse método são: a) o uso da fala espontânea que reflete melhor o conhecimento lingüístico da criança; b) ao querer observar um processo lingüístico, o pesquisador pode acabar deparando-se com outros, o que contribui com o

${ }^{7}$ Os estudos sobre percepção da fala investigam como os indivíduos, de feto a adultos, percebem os sons da língua, enquanto que e os estudos de compreensão investigam o que a criança entende (KARMILOFF\& KARMILOFF-SMITH, 2001). 
desenvolvimento de pesquisas futuras ou complementares a que está sendo desenvolvida; c) contato com todos os componentes da língua em uso; d) contato com diversos tipos de palavras (comuns, particularmente infantis, diferentes classes gramaticais, etc). Porém, existem alguns aspectos negativos: a) falta de controle do output; b) às vezes o que se busca analisar ocorre poucas vezes ou nem ocorre nas sessões gravadas; c) número reduzido de indivíduos participantes no estudo; d) tempo longo de coleta.

No outro método, o experimental, escolhe-se um conjunto de estímulos de uma maneira controlada, i.e. pré-estipulada. Os dados são, assim, recolhidos por meio de alguma técnica de elicitação em laboratórios ou em outro ambiente de trabalho. O objetivo desse tipo de método é testar se uma determinada predição está incorreta, ou contribuir na reformulação de uma teoria baseando-se em evidências dadas pelos resultados dos experimentos. O processo de construção de um experimento envolve, em geral, as seguintes etapas: formulação da hipótese, seleção da população, escolha do tipo de método experimental, coleta de dados e transcrição da fala a ser analisada.

O método experimental apresenta diferentes estratégias de elicitação. A produção lingüística pode ser obtida pedindo que a criança repita algum enunciado (imitação elicitada) ou que a criança crie um enunciado (produção elicitada). Segundo Crain \& Wexler (1999), a imitação elicitada é uma estratégia experimental viável para os estudos de aquisição, como será discutido adiante.

Alguns aspectos positivos desse método são: a) maior quantidade de dados; b) seleção mais rápida do fenômeno lingüístico a ser analisado (uma vez que é o único a ser produzido); c) curto tempo de coleta. Porém, existem alguns aspectos negativos e o principal deles é que ao pré-estabelecer as formas de elicitação, podem ficar de fora algumas outras características (lingüísticas ou não-lingüísticas) que afetam a produção do 
que é esperado, mas que o pesquisador não levou em conta ao (consciente ou inconscientemente) preparar o experimento.

Percebe-se, então, que ambas as metodologias apresentam pontos positivos e negativos, e apresentam características que as diferenciam de uma maneira geral, i.e. a fala espontânea na observacional e a fala controlada na experimental. Em geral, pode-se afirmar que ambas as metodologias são válidas para o estudo sobre a aquisição da língua e que de acordo com o que foi exposto até o momento, aparentemente, não haveria uma característica que fizesse o estudo sobre um determinado fenômeno lingüístico apresentar diferentes resultados de acordo com a metodologia empregada. No entanto, essa discrepância entre os resultados de estudos que empregam metodologias diferentes ocorre no cenário da literatura aquisicionista brasileira.

Um fator que pode influenciar nos resultados do experimento é que de acordo com a faixa etária da criança, o experimentador pode precisar utilizar a imitação elicitada. Crain \& Thornton (2000) afirmam que mesmo na imitação as crianças não falam como o adulto, e que as mudanças (ou erros) que elas produzem podem indicar que a gramática subjacente delas é diferente da do adulto. Dessa maneira, a imitação é considerada a reconstrução do estímulo e não apenas uma cópia passiva. Ela não é algo mecânico (SCARPA, 1984), e mesmo que essa reconstrução seja mais 'visível' na produção sintática por causa da produção de sentenças maiores que exigem mais processamento, ela não deixa de ocorrer na produção fonética/fonológica, em que são encontrados processos envolvidos durante a produção da criança: apagamento de sílabas, adição de segmentos, deslocamento de acento, etc. Todavia, Taelman \& Gillis (2001), ao estudarem o processo de apagamento, confrontam produções espontâneas e imitações, e concluem que há diferenças estatísticas relevantes nas palavras produzidas com imitação em relação às espontâneas. É observado 
que $13 \%$ das produções imitadas sofreram apagamento, enquanto que $18 \%$ das produções espontâneas sofreram $\left(\chi^{2}(1)=20.02 ; \mathrm{p}<.001\right)$.

Nesta pesquisa, assume-se que a imitação é uma reconstrução do estímulo e que, por mais que possa diferenciar-se da produção espontânea, não se trata de uma simples cópia, pois os dados infantis apresentam processos lingüísticos ausentes na fala alvo, como, por exemplo, o apagamento em dissílabos que favorece a produção de monossílabos (boné > né, bola $>$ bo).

O quadro 3 resume as características de cada método e as compara:

\section{Passos para geração de dados Experimental Observacional \\ (naturalístico)}

\begin{tabular}{|l|l|l|}
\hline 1. Formular a hipótese & Sim & Sim \\
\hline 2. Desenvolver o design & Sim & Não \\
\hline 3.Construir método de elicitação & Sim & Não \\
\hline 4. Selecionar população & Sim & Sim \\
\hline 5. Coletar dados & Sim & Sim \\
\hline
\end{tabular}

Quadro 3: comparação entre os métodos de estudo

Como o quadro 3 mostra, os dois métodos só deixam de compartilhar os passos 2 e 3. Dessa maneira, este estudo pretende responder se por causa desses dois passos estudos que não optam pelo mesmo método podem apresentar resultados diferentes, embora analisem o mesmo fenômeno em dados de uma população semelhante. No que se refere ao item 2, deve-se também levar em conta o tipo de léxico utilizado no experimento que, como será discutido na próxima seção, parece desenvolver um papel importante na tendência prosódica inicial. 


\subsubsection{Sobre o léxico contemplado em cada método}

O léxico contemplado em cada método pode influenciar no resultado, pois, como será mostrado na próxima seção, no que se refere ao PB, estudos observacionais, que lidam com os dados na sua totalidade, i.e. incluindo dados de léxico comum e particular (produções familiares e criações lexicais), afirmam uma tendência prosódica inicial, enquanto que o experimental, que lida apenas com o léxico comum, afirma outra.

O léxico particular é composto por criações lexicais e produções familiares, dois termos que foram retirados do manual do Childes (MAcWHINNEY, 1991). No entanto, não apenas o tipo de léxico pode estar influenciando, mas a classe de palavras também, pois os estudos observacionais analisam dados de verbos e nomes, enquanto que o experimental conduzido por Rapp (1994) analisou somente nomes.

Santos (2007) realiza um trabalho minucioso a respeito da influência do input, das produções familiares $^{8}$ e da classe de palavras no modelo prosódico inicial, analisando dados de duas crianças (L. e R.) de 1;3 a 2;0 anos. As conclusões referentes ao tipo de léxico e classe de palavras encontram-se a seguir.

\section{Léxico particular - criações lexicais}

$\mathrm{O}$ único trabalho encontrado sobre o $\mathrm{PB}$, que analisa as criações lexicais, é o desenvolvido por Secco (1994). O autor argumenta que não se deve confundir criação lexical com neologismo, pois são fenômenos diferentes: "A criação lexical é um tipo

\footnotetext{
${ }^{8}$ A autora analisa dados de produções familiares e não analisa dados de criações lexicais.
} 
específico de item lexical, o qual não faz parte do léxico estabelecido na comunidade lingüística na qual a criança se insere" (SECCO, 1994:01). Secco prossegue afirmando que as criações lexicais são instáveis, isto é, apresentam um período pequeno de duração, e funcionam como preenchedores de lacunas da fala da criança.

Adiante, são apresentados exemplos de criações lexicais encontradas no conjunto de dados desta pesquisa:

$\begin{array}{lll}(01) \text { [ di.'ko ] }- & \text { bola } & (\text { J.V-DEX) } \\ (02) \text { ['ka.ke] }- & \text { cachorro } & \text { (G.A-DEX) } \\ (03) \text { [pa.'da] }- & \text { anel } & \text { (C.M-DEX) } \\ (04) \text { ['pa.kr] }- & \text { sofá } & \text { (I.S-DEX) } \\ (05) \text { [pi.'pi]- } & \text { pássaro } & \text { (LUI-DES) } \\ (06) \text { [ta.'ta] } & \text { chulé } & \text { (LUI-DES) }\end{array}$

Secco (1994) encontra produções de alguns itens que não seguem o padrão fonotático da língua ([km.’km] "quero" ou "caneta”) e, por essa razão, o autor considera que algumas produções iniciais podem fugir do inventário fonético/fonológico da forma alvo. Todavia, como os dados de (01 - 06) ilustram, nesta pesquisa não há caso que viole a fonotática do $\mathrm{PB}$, nem mesmo nos anteriores à faixa etária de 1;8 anos (investigada por Secco 1994), por isso não se confirma que a criança nessa faixa etária fuja da fonotática da língua.

Secco (1994) sugere que há dois processos de criação lexical: o primeiro é o da reduplicação: [mu.'mu] 'muro', [ka.'ka] 'carro', [lu.'lu] 'luta' etc; o segundo é o uso de

\footnotetext{
${ }^{9}$ DEX: dado experimental / DES: dado espontâneo (naturalístico)
} 
onomatopéia como criação lexical. O pesquisador afirma que há momentos em que a criança passa a referenciar o objeto pelo significante onomatopaico. São apresentados os seguintes exemplos:

a. vum@c "secador de cabelo", com a variação um@c, são criações lexicais formadas a partir do som produzido pelos secadores de cabelo.

b. pom@c "tampa" surge do som que as tampas fazem ao serem colocadas em cima dos objetos que cobrem.

(SECCO, 1994:71)

Secco (1994) não observou a distribuição do acento nos dados de criação lexical, pois esse não era um de seus objetivos. Tal observação é feita por Baia (2006) que afirma, com base na análise de dados naturalísticos, que o modelo prosódico predominante nas criações lexicais é o iâmbico.

\section{Léxico particular - produções familiares}

Considera-se produção familiar um tipo de léxico presente na aquisição de qualquer criança falante de uma língua específica; por exemplo, em português, 'nanar' e 'papar' (cf. SANTOS, 2006, 2007; BAIA, 2006). São palavras que as crianças nos primeiros estágios utilizam e repetem com muita freqüência. Dessa maneira, o que as distingue das criações lexicais é o fato de que elas são comuns e similares na aquisição de qualquer criança falante de uma mesma língua, ao contrário das criações lexicais, que são instáveis. A literatura (FERGUSON, 1964; STOEL-GAMMON, 1976; ELLIOT, 1992 e CLARK, 2005) costuma afirmar que este tipo de léxico é característica de baby talk ou nursery language 
(JAKOBSON, 1972). Além disso, consideram-se produções familiares os dados de apelidos (hipocorísticos) que aparecem na fala infantil. Obviamente, os nomes diferem de criança para criança, porém os processos parecem ser os mesmos: reduplicação e apagamento, por exemplo, que resultam em produções que ao contrário das criações lexicais não são instáveis. Uma definição sobre hipocorização é elaborada por Gonçalves (2004):

Hipocorização é o processo pelo qual nomes próprios são abreviados afetivamente, resultando numa forma diminuta que mantém identidade com o prenome ou com o sobrenome original. Hipocorísticos devem ser interpretados, pois, como apelidos.

(GONÇALVES, 2004: 36)

Cabe chamar a atenção de que o processo de hipocorização não ocorre apenas com a reduplicação, porém ela é enfatizada, neste presente estudo, por parecer ser o processo mais freqüente na fala infantil quando o alvo é nome próprio. Veja os exemplos (07) e (08) a seguir, que ilustram um caso de reduplicação e um caso de apagamento na palavra:

(07) $[\mathrm{ka} . ' \mathrm{ka}]$ Rebeca (LUI-DES)

(08) ['be.ke] Rebeca (LUI-DES)

Como será discutido na análise dos dados, as produções familiares apareceram apenas no conjunto de dados naturalísticos desta pesquisa, pois nos experimentais esse tipo de produção não foi requisitada. A seguir, são apresentados exemplos desse tipo de dado em produções espontâneas (DES). 

(09) [na.'na]
nanar (dormir)
(LUI-DES)
(10) [te.'te]
mamadeira
(LUI-DES)

Santos (2006) e Baia (2006) chamam a atenção que o iambo é o modelo prosódico predominante nas produções familiares. Santos (2007), em um estudo mais minucioso, analisa as produções familiares e observa que, quando se tratavam de nomes, prevaleceu a produção de monossílabos tônicos nas idades contempladas (de 80 a 100\%), mas quando verbos, prevaleceu a produção de iambos (de 95 a 100\%).

Essa predominância de iambos em dados particularmente infantis já tinha sido alvo de comentários anteriores como o de Stoel-Gammon:

(...) In the majority of BP items, the accent is on the final syllable. This stress pattern contrasts sharply with the pattern found in as Portuguese where the stress generally falls on the penultimate syllable.

(STOEL-GAMMON, 1976: 24)

Dessa forma, o léxico particular está presente, principalmente, nos dados naturalísticos e é predominantemente iâmbico. Logo esse tipo de léxico pode contribuir na discrepância encontrada entre os resultados do estudo experimental e dos estudos observacionais.

A classe gramatical das palavras: nomes vs verbos

Santos (2007) observa um comportamento diferenciado do modelo prosódico em nomes e verbos. A autora analisa cada classe gramatical desconsiderando dados de 
produções familiares. No que se refere aos nomes, de 1;3 a 2;0 anos prevaleceram os iambos (mínimo de $70 \%$ e máximo de $100 \%$ por mês analisado) e quando o alvo era WSW, o recorte WS foi predominante até 1;5 anos; após essa faixa etária prevaleceu o recorte de SW. No que se refere aos verbos, até 2;0 anos a produção de monossílabos é predominante (mínimo de $95 \%$ e máximo de $100 \%$ por mês analisado) e quando o alvo era WSW, prevaleceu o recorte SW. Dessa maneira, observa-se um comportamento diferenciado dos nomes em relação aos verbos. Além disso, os resultados da autora mostram que mesmo sem a presença das produções familiares a predominância iâmbica permanece e que os verbos são, majoritariamente, monossílabos, enquanto os nomes são dissílabos iâmbicos. Dessa maneira, mesmo desconsiderando dados de produções familiares a tendência iâmbica permaneceu nos dados de léxico comum da autora.

Resumindo o que foi discutido até agora, o tipo de léxico e a classe gramatical parecem alterar a tendência prosódica básica, e por isso é necessário levá-los em conta na análise. 


\section{ESTUDOS PRÉVIOS SOBRE O MODELO PROSÓDICO INICIAL}

O modelo prosódico inicial tem sido alvo de estudos que lidam com produção (ALLEN \& HAWKINS, 1980; GERKEN, 1994; SANTOS, 2007) e de estudos que lidam com percepção (ECHOLS \& NEWPORT, 1992). No entanto, esta dissertação trata apenas de dados de produção, fugindo, assim, do seu escopo as possíveis influências da percepção na produção prosódica aqui analisada. Adiante, são apresentados os estudos que tratam da tendência prosódica inicial nos dados de produção infantil em línguas germânicas, românicas, semíticas, entre outras.

\subsection{Nas línguas germânicas - o início da discussão}

Allen \& Hawkins (1980), ao estudarem o apagamento de sílabas fracas iniciais em palavras polissilábicas na aquisição do inglês, perceberam que as crianças preferiam o acento decrescente (SW) ao acento crescente (WS), i.e. pés trocaicos foram predominantes nos resultados obtidos. Após esses resultados, os autores levantaram a hipótese de que a preferência pelo troqueu no estágio inicial de aquisição não seria algo particular da aquisição do inglês, mas presente na aquisição de qualquer língua.

Após o estudo de Allen \& Hawkins, diversas pesquisas foram conduzidas no intuito de se verificar a suposta predominância de troqueus nos dados infantis iniciais. A seguir, são apresentados estudos em diferentes línguas que partiram para essa verificação e suas conclusões. 
i. Inglês: Confirmando os achados de Allen \& Hawkins (1980), Gerken (1994) defende que nos estágios iniciais de aquisição a produção do modelo SW é predominante, refletindo, assim, uma tendência inata. Portanto, o estudo oferece maior sustentação ao que foi observado por Allen \& Hawkins (1980). Para chegar a tais resultados, Gerken conduziu um experimento no qual foi pedido que as crianças repetissem logatomas de quatro sílabas (SWWS e WSWS); e tais repetições apresentaram predominância da produção da seqüência SW.

Dando seqüência a esses estudos, após analisar dados com apagamento de sílabas, Archibald (1995) confirma a existência de uma tendência trocaica na aquisição do inglês e a possibilidade dessa tendência ocorrer em outras línguas. A mudança (ou inovação) no seu estudo é terminológica e esquemática: as sílabas fracas iniciais são chamadas de resíduo e o modelo trocaico de base. $\mathrm{O}$ autor explica que, nos primeiros estágios de aquisição, a criança produz a base e elimina o resíduo.

No entanto, nem todos os estudos sobre o inglês confirmam a tendência trocaica inicial como sendo uma tendência inata. Um deles é o estudo de Klein (1984), o qual afirma que o acento é adquirido, inicialmente, com base na relação entre as características segmentais e prosódicas do léxico. Dessa maneira, entende-se que para o autor o acento é adquirido de palavra em palavra. Para chegar a tal conclusão, o autor acompanhou, em um estudo de caso, uma criança de aproximadamente 2 anos na aprendizagem do acento em inglês, utilizando um repertório de palavras polissilábicas produzidas pela criança. Os troqueus foram predominantes; porém, segundo o autor, isso não ocorre devido a uma tendência inata, mas ao pé básico da língua que é o troqueu. A conclusão do autor não deixa de ser interessante, porém, ao afirmar que o acento é adquirido com base no léxico, o autor ignora dados de criação lexical que são apresentados no seu trabalho. Se a produção 
do acento fosse resultado de um processo de memorização, não haveria esse tipo de léxico inventado, ou este tipo de léxico seria produzido sem nenhum tipo de proeminência acentual, pois a criança não teria como produzir algo que não memorizou.

Um outro estudo que questiona a universalidade do troqueu com base em dados do inglês é o de Kehoe \& Stoel-Gammon (1997). Neste estudo, as autoras verificam as avaliações e conclusões presentes na literatura sobre a aquisição da estrutura prosódica no inglês, e afirmam que os estudos anteriores, os quais afirmam, categoricamente, a tendência trocaica, apresentam falhas por considerarem o iambo marginal, pois a maior parte dos dados de erros de acento, na produção infantil, são direcionados para o pé iâmbico:

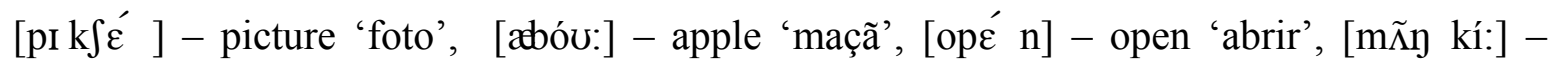
monkey 'macaco' (KEHOE \& STOEL-GAMMON, 1997: 138).

O último estudo a ser apresentado, que questiona a hipótese da universalidade do troqueu, é o de Vihman, DePaolis \& Halle (1998) que apresenta uma análise acústica dos dados de palavras e vocalizações de crianças de 1;1 -1;10 anos. Baseando-se no fato de que no inglês as palavras são majoritariamente trocaicas (74\%) e as frases são iâmbicas (75\%), os autores afirmam encontrar, no conjunto de dados, produção de iambos, que, segundo eles, seria ocasionada pela interferência da proeminência acentual de níveis prosódicos superiores.

No entanto, apesar desses estudos não confirmarem a tendência trocaica como sendo universal, o que prevalece nos dados de todos eles é a produção de troqueus, mesmo que tenham sido encontrados dados de iambo ou evidências a favor de um acento lexical memorizado palavra por palavra. Portanto, não foram apresentadas evidências fortes o bastante que fossem contra a hipótese da tendência trocaica. 
ii. Holandês: Um dos estudos mais conhecidos sobre a aquisição prosódica do holandês é o de Fikkert (1994), que assume a tendência trocaica como tendência inata, decorrente do troqueu ser o pé default, i.e. dado pela GU. A autora chega a essa conclusão após a análise de processos de apagamento e adição de segmentos que, majoritariamente, favorecem a produção de troqueus na aquisição do holandês.

Demuth (1995) argumenta que a criança, na sua gramática inicial, utiliza dois modelos prosódicos principais, que são: a sílaba universal (core syllable CV) e a palavra mínima (minimal word), composta por um pé binário trocaico. Segundo a pesquisadora, a sílaba universal e o pé binário são dados pela $\mathrm{GU}$, e, por essa razão, podem ser considerados como estruturas default. Utilizando dados retirados do estudo de Fikkert (1994), a autora mostra que crianças adquirindo o holandês apresentam a tendência de transformar monossílabos em pé trocaico, inserindo uma vogal entre duas consoantes coda (CVCC - CVCVC) ou inserindo uma vogal em sílabas fechadas (CVC - CVCV). Dessa maneira, nota-se que tanto Fikkert (1994) quanto Demuth (1996) defendem o troqueu como modelo prosódico inicial.

Um outro estudo que confirma a predominância de troqueus no holandês é o de Wijnen, Krikhaar \& Den Os (1994), no qual é analisada a não realização de elementos desacentuados na tentativa de produção de polissílabos. Após analisarem a omissão de segmentos em palavras com mais de três sílabas, os autores notam que a maioria das produções é trocaica. Porém, Wijnen et al. não concluem que o aspecto universal deva ser atribuído ao modelo trocaico, pois para eles a interferência não é de uma tendência prosódica inata, mas sim do apagamento das sílabas fracas. Dessa maneira, o processo universal presente na fala infantil, segundo os autores, é a omissão de sílabas fracas. 
No entanto, um outro estudo sobre o holandês não afirma haver uma predominância de troqueus nos dados iniciais. Taelman (2004) analisa dois processos, o apagamento de sílabas e a epêntese, utilizando dados naturalísticos de uma criança entre 1;8 - 1;11 anos. A autora afirma o seguinte a respeito da produção prosódica do holandês:

However, the empirical evidence suggests that there is no universal predisposition for a trochaic rhythmic pattern. Neither is there a preference for the word final syllable in all language and for all prosodic patterns (...)

(TAELMAN, 2004: 44)

Apesar de não afirmar a preferência por algum modelo prosódico inicial, a autora nota a ocorrência de apagamento de sílaba favorecendo o pé iâmbico. Por essa razão, é afirmado que o pé iâmbico, que tem sido considerado marginal pela literatura que lida com a forma prosódica inicial nas línguas germânicas, não deixa de ser produzido pelas crianças holandesas no estágio inicial de aquisição. A fim de fortalecer tal argumento, Taelman afirma que, freqüentemente, palavras alvo WSW sofrem apagamento que resulta em um pé

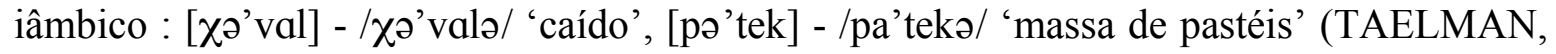
2004:142).

Como se pode perceber, em holandês, é encontrada, assim como nos estudos do inglês, uma tendência para produção de troqueus e indícios de que a produção de iambos não é tão marginal como costuma ser assumido.

iii) Alemão: O estudo conduzido por Grimm (2004) afirma que as crianças alemãs, no estágio inicial de aquisição, produzem, predominantemente, troqueus. No entanto, foi 
observado que aos 1;6 anos houve produções iâmbicas quando as palavras eram produzidas isoladamente. Tal fato é explicado pela autora como sendo interferência de níveis prosódicos maiores, a saber, o frasal ou entoacional (o mesmo é defendido por autores como Scarpa (1997), Vihman et al. (1998) e Santos (2001) na explicação acerca da ocorrência de iambos na aquisição do inglês, escocês e PB).

Neste levantamento a respeito das línguas germânicas, observou-se que a maioria dos estudos levanta indícios a favor da predominância de troqueus, mesmo que alguns não considerem haver uma tendência prosódica inata e apresentem exemplos de produções iâmbicas que vão contra a tão assumida marginalidade do iambo.

\subsection{Em Sesoto, Quiché e Hebraico}

i) Sesoto: Demuth (1996) investiga a aquisição prosódica em sesoto, língua africana que marca o acento lexical com o alongamento da penúltima sílaba. Segundo a autora, a maior parte das produções no estágio de uma palavra são, nessa língua, representadas pelo pé trocaico $(\mathrm{SW})$.

ii) Quiché: Uma outra língua investigada por Demuth (1996) é Quiché, língua maia na qual a sílaba proeminente sempre é a final. No entanto, a autora observa nos dados iniciais que as primeiras palavras são, freqüentemente, monossilábicas.

No intuito de explicar tal comportamento prosódico das produções infantis em Quiché e Sesoto, Demuth afirma que o modelo das primeiras palavras produzidas pelas crianças é restringido pelos princípios da $\mathrm{GU}$, os quais permitem a produção da sílaba 
universal $(\mathrm{CV})$ ou da palavra mínima. Essa é a mesma análise proposta pela autora para o inglês.

iii) Hebraico: Segundo Adam \& Bat-El (2007), o hebraico é uma língua em que a maior parte do léxico é iâmbica (70\%) e que, por essa razão, seria de se esperar um maior número de iambos nas produções infantis. No entanto, os autores, ao investigarem a tendência prosódica inicial nos dados do hebraico, notam que a maior parte das palavras iâmbicas é produzida como monossílabos, enquanto que as palavras trocaicas são produzidas de acordo com a forma alvo e os erros são direcionados para o pé trocaico. Por conseguinte, os autores atribuem à GU a predominância trocaica nos dados infantis, pois se o troqueu não é o pé predominante da língua e está presente nos dados infantis, isso pode ser uma evidência a favor do troqueu como modelo prosódico inato. Porém, estudos como o de Bolozky (1982) e Glinert (1989) sobre a língua adulta afirmam haver uma predominância de troqueus na língua hebraica e não maior ocorrência de iambos como Adam \& Bat-El (2007) apresentam. Tal fato enfraquece o argumento dos autores de que os dados infantis hebraicos fortificam a universalidade do troqueu.

Os estudos apresentados deixam de apresentar indícios contra a tendência trocaica, pois quando não houve produção dissilábica que não favorecesse o pé trocaico, houve uma maior produção de monossílabos. 


\subsection{Nas línguas românicas}

i) Espanhol: Após analisar dados naturalísticos de quatro crianças bilíngües (espanhol e inglês), Hochberg (1988a) chega à conclusão de que as primeiras produções da criança indicam que há um início neutro (neutral start), i.e. não houve evidências, na análise da autora, de preferência por um tipo particular de acento. Foi analisada a fala espontânea e imitada de quatro crianças que, segundo a autora com base nas produções com acerto de acento, não mostraram evidências a favor de nenhum modelo prosódico específico. ${ }^{10}$

Em um segundo estudo, agora experimental, Hochberg (1988b) utiliza dados de nomeação imitada de logatomas. Participaram do experimento cinqüenta crianças bilíngües (espanhol e inglês). O objetivo é demonstrar que as crianças que estão adquirindo o espanhol aprendem regras para determinar o acento e que começam produzindo o acento mais regular na língua (o da penúltima sílaba), contrariando aquelas afirmações de que as crianças simplesmente memorizam a colocação do acento em cada palavra (KLEIN, 1984) ou que vêm com um modelo prosódico inato (GERKEN, 1994; FIKKERT, 1994; DEMUTH, 1996). A autora observa que os erros de acento ocorreram mais na produção de

$\overline{{ }^{10} \text { A autora contabilizou os dados de cada criança separadamente: }}$

TABLE 4. Percent correct stress on penuktimate-and final-stressed models for the four children

\begin{tabular}{|c|c|c|c|c|}
\hline \multirow[b]{2}{*}{ Child } & \multicolumn{2}{|l|}{ Spontaneous } & \multicolumn{2}{|l|}{ Imitated } \\
\hline & $\begin{array}{c}\text { Penultimate } \\
(\%)\end{array}$ & $\begin{array}{r}\text { Final } \\
(\%)\end{array}$ & $\begin{array}{c}\text { Penultimate } \\
(\%)\end{array}$ & $\begin{array}{l}\text { Final } \\
(\%)\end{array}$ \\
\hline Ana & $55(498)$ & $63(81)$ & $58(281)$ & $61(44)$ \\
\hline Elsa & $55(497)$ & $60(183)$ & $70(364)$ & $49(81)$ \\
\hline Miguel & $52(104)$ & $57(67)$ & $64(87)$ & $55(22)$ \\
\hline Pedro & 74 (198) & $57(23)$ & 79 (120) & 64 (14) \\
\hline
\end{tabular}

(HOCHBERG, 1988a: 281) 
logatomas com acento irregular ( $43 \%$ dos casos de erro e o restante de acerto), enquanto que na produção de logatomas com acento regular os erros ocorreram com menos freqüência ( $22 \%$ de erros e o restante de acerto). ${ }^{11}$

ii) Francês: Allen (1983), após seu trabalho com Hawkins em 1980, verifica a tendência trocaica na aquisição do francês, língua que apresenta um maior número de iambos na forma alvo. $\mathrm{O}$ autor realiza um estudo experimental no intuito de verificar se a tendência trocaica encontrada no inglês, língua com maior número de troqueus, se aplicaria na aquisição de uma língua iâmbica. Para isso, Allen analisa o contorno supra-segmental em dados de crianças francesas de 2 anos de idade e conclui que as crianças, nessa idade, são influenciadas pela prosódia da forma alvo, mas que ao mesmo tempo têm as suas primeiras produções controladas por restrições universais da produção da fala. Essas restrições estão relacionadas com a capacidade de articulação, segundo o autor, e, por essa razão, troqueus e dátilos são produzidos com mais facilidade do que iambos e anapestos, pois exigem menos esforços articulatórios. Dessa maneira, a produção de troqueus não é considerada um primitivo da GU, mas está ligada às restrições articulatórias, o que faz com que a proposta do autor esteja relacionada com a lei do menor esforço.

No entanto, os resultados apresentados por Demuth \& Johnson (2003) sobre a aquisição do francês contrapõem-se aos de Allen (1983). No estudo, Demuth \& Johnson analisam um fenômeno freqüente na aquisição do francês, a saber, o apagamento de sílabas, que favorece a produção de uma sílaba de uma mora.

\footnotetext{
${ }^{11}$ Neste estudo, a autora afirma que o acento primário no espanhol ocorre em uma das três últimas sílabas da palavra. Dessa maneira, entende-se que o que Hochberg chama de logatoma com acento regular é o que apresenta o acento em alguma das três últimas sílabas.
} 
Ao analisarem dados naturalísticos de uma criança de 1;1 - 1;8 anos, os autores notam que o pé das palavras iniciais é o iambo (DEMUTH \& JOHNSON, 2003: 217), pois quando não foram produzidas como monossílabos, as palavras iâmbicas, que predominam na língua, foram produzidas como dissílabos iâmbicos. Em um estudo seguinte, Demuth (2003) afirma que a forma dissilábica não é predominante, pois os monossílabos predominam. Porém, Vihman et al. (1998), ao analisarem e compararem a aquisição do inglês e francês, notam que as crianças francesas não preferem monossílabos no estágio inicial:

(...) children acquiring English tend to prefer monosyllables, whereas children acquiring French produce as many words with three or more syllables as words with only one (...)

(VIHMAN et al., 1998: 936)

Apesar de não haver consenso quanto ao tamanho do modelo prosódico inicial na aquisição do francês (uma sílaba ou dissílabo), nota-se que a maior parte dos estudos não encontra indícios a favor da tendência trocaica na aquisição do francês.

iii) Catalão: Prieto (2005) verifica as propriedades e influências do input da língua investigada nos primeiros modelos do output da criança. No estudo, são analisados dados naturalísticos de 6 crianças catalãs de 1;11 - 2;8 anos, os quais mostram haver produções tanto iâmbicas quanto trocaicas. Todavia, enquanto os troqueus dissilábicos são sistematicamente produzidos como SW (ex. globus [' $\beta \jmath ß u]$ 'balão’), os iambos dissilábicos podem ser produzidos ou sofrer apagamento como (W)S (aqui [ $\left.\mathrm{e}^{\prime} \mathrm{t}^{\mathrm{h}} \mathrm{i}\right]$ ou [' $\left.\mathrm{t}^{\mathrm{h}} \mathrm{i}\right]$ 'aqui'). Além disso, no caso de seqüências WSW, a sílaba pretônica aparece tardiamente: sabata é 
pronunciada como ['batə] 'sapato', pilota ['t $\left.\mathrm{t}^{\mathrm{h}} \mathrm{\jmath} \mathrm{te}\right]$ 'bola', aquesta [' $\mathrm{k}^{\mathrm{h}} \varepsilon \mathrm{k}^{\mathrm{h}} \mathrm{e}$ ] 'esta'; e, por volta de $1 ; 10-2 ; 0$ anos, as crianças catalãs mostram um contraste entre o apagamento de formas WS e WSW: enquanto a primeira forma é produzida completamente, a segunda sofre apagamento formando um troqueu dissilábico (pilota [' $\left.\mathrm{t}^{\mathrm{h}} \mathrm{\jmath} \mathrm{te}\right]$ 'bola') (Prieto, 2005: 2).

Restringindo-se ao processo de apagamento de sílabas, Prieto (2005) vai explicar que esse fenômeno não é comum em alvo troqueu devido à predominância de troqueus na fala dirigida à criança e na fala entre adultos. Portanto, os dados parecem indicar uma tendência trocaica na aquisição do catalão, pois SW é produzido como SW, WS é produzido como S e WSW como SW.

iv) Português Europeu (PE): No estudo de Correia, Costa \& Freitas (2006), são apresentados dois estágios na fala inicial das crianças portuguesas: estágio I (0;11 - 1;6 anos), em que há predominância de monossílabos e de iambos (cerca de $65 \%$ de produções iâmbicas); estágio II (1;7 - 2;4 anos), em que há a emergência do troqueu, diminuição de monossílabos e de iambos (os troqueus passam a predominar em torno de $70 \%$ ). Nota-se que o PE, apesar de ser uma língua de predominância trocaica, assim como o PB, apresenta nos dados infantis iniciais uma maior emergência de iambos no estágio I.

v) PB: Com o resumo dos estudos expostos até então, pôde-se notar que os dados infantis ou demonstram uma tendência de acordo com a forma alvo (inglês, holandês, alemão, francês, catalão, etc) ou não demonstram nenhuma tendência predominante (espanhol). No entanto, o PB além de apresentar resultados que não vão bem ao encontro 
dos estudos realizados em outras línguas, como será mostrado a seguir, apresenta uma discrepância interna nos estudos que adotam diferentes metodologias: enquanto o experimental afirma uma tendência prosódica, o observacional defende outra. A seguir, são apresentados os resultados obtidos com o uso dos diferentes métodos.

\section{Estudo Experimental}

O único estudo experimental brasileiro acerca do modelo prosódico inicial, conhecido até então, é o de Rapp (1994). A autora realiza o estudo no intuito de analisar o processo de apagamento de sílabas fracas na aquisição do PB como língua materna, analisando 393 produções de palavras (léxico comum) de 8 crianças entre 1;6 e 2;0 anos. Após a transcrição perceptual dos dados, a pesquisadora conclui o seguinte a respeito da preferência prosódico-lexical das crianças:

Em síntese, o padrão lexical preferencial, na faixa etária investigada $(1 ; 6$ 2;0), é o dissílabo paroxítono, impulsionando, desta forma, nesta direção, as simplificações de ordem prosódico-lexical encontradas nos enunciados infantis investigados (...)

(RAPP, 1994:162)

$\mathrm{Na}$ sua análise, a autora encontra $54,7 \%$ das produções trocaicas; e os dados restantes foram produções iâmbicas $(40,7 \%)$ e trissilábicas $(4,6 \%)$. Como o objetivo da pesquisadora era o de analisar apenas o processo de apagamento e o modelo prosódico resultante, os erros de acento não foram analisados. Não foi verificado se eles tenderiam a favorecer o dissílabo paroxítono (troqueu) ou algum outro modelo. Em vista disso, são 
retomados os dados apresentados por Rapp (1994) no apêndice da sua tese, observando as produções com erros de acento. Das 393 (100\%) palavras, houve erro de acento em 16 (4,07\%) e desses 16 dados com erros pôde-se observar que:

i. Em 62,5\% (10) dos exemplos, o erro de acento é direcionado para a sílaba final, resultando, assim, em pés iâmbicos ao invés de trocaicos - paroxítona que se torna oxítona, [ka.’xu] 'carro' (p.169);

ii. Em 37,5\% (6) dos exemplos, o acento é deslocado da sílaba final para a penúltima, resultando, assim, em pés trocaicos ao invés de pés iâmbicos oxítona que se torna paroxítona, ['ã. bo] - tambor (p.170).

Os dados de erros apontam uma direção iâmbica, porém nos dados gerais da autora a produção de troqueus foi predominante.

\section{Estudos observacionais (naturalísticos)}

Como será notado com a exposição dos estudos a seguir, há mais estudos que utilizam o método observacional do que os que utilizam o experimental no $\mathrm{PB}$. $\mathrm{O}$ diferencial entre esses dois tipos de estudos está na metodologia e, particularmente, no léxico contemplado. Como foi citado anteriormente, o estudo experimental de Rapp (1994) lida apenas com o léxico comum e nomes. Os estudos observacionais, apresentados adiante, contemplam os dados na sua totalidade, incluindo, dessa maneira, léxico comum e léxico particular, dados de nomes e verbos. 
Scarpa (1997) segue a hierarquia prosódica proposta por Nespor \& Vogel (1986) e atribui a tendência iâmbica presente na aquisição do $\mathrm{PB}$ à influência de domínios prosódicos superiores. A autora assume que a aquisição segue uma seqüência top-down (da frase para a palavra) e não bottom-up (do pé para a palavra), assim, as crianças começam a adquirir os domínios mais baixos da hierarquia prosódica, como a palavra fonológica e pés, ainda fazendo uso do acento de domínios superiores, como o entoacional. Segundo a autora, há uma maior ocorrência de iambos na aquisição do PB devido ao uso da proeminência acentual de domínios superiores da hierarquia. Dessa maneira, pode-se considerar dois níveis de acento nos dados iniciais de aquisição: o acento frasal (accent) e o da palavra (stress). Da maior parte dos estudos relatados até então, apenas o de Vihman et al. (1998), Santos (2001) e Grimm (2004) vão assumir a posição top-down, enquanto que o restante assume que a ordem é bottom-up.

Em um primeiro momento, Santos (2001), analisando dados naturalísticos de duas crianças de 1 a 3 anos (T. e R.), argumenta que se as crianças estão lidando com algum constituinte métrico, há a possibilidade de ser trocaico ou iâmbico, mas não se pode afirmar que há uma tendência preponderante. Dessa maneira, a autora não confirma a tendência trocaica, e no intuito de mostrar a variabilidade na produção prosódica, apresenta a seguinte seqüência: $1 ; 5-1 ; 8$ anos há uma tendência iâmbica, de 2;1 - 2;9 anos ocorre um equilíbrio entre as duas formas (com exceção de 2;1, quando há um privilégio das formas $\mathrm{SW}$ ), e de 2;9 - 3;0 anos há uma tendência de produção de WS (cf. Santos, 2001: 252). De acordo com essa seqüência, a análise da autora mostra uma tendência iâmbica no primeiro momento, um equilíbrio de iambos e troqueus no segundo, e, no terceiro, uma tendência que favorece a produção de iambos novamente. Pela tendência iâmbica prevalecer em dois 
estágios, este estudo assume que, em geral, houve indícios a favor de uma tendência iâmbica nos dados iniciais do PB apresentados por Santos.

Em um segundo momento, Santos (2007), analisando dados de duas crianças entre 1 e 3 anos, encontra mais indícios a favor de uma tendência iâmbica inicial. Ao contrário do seu trabalho de 2001, que considera a ordem de aquisição top-down, a autora considera, neste segundo momento, que a ordem seja bottom-up. É observado que tal tendência não ocorre devido a uma estratégia de evitação de certas estruturas por parte da criança, nem devido à influência do input, e nem se trata de uma estratégia de otimização rítmica, pois mudança de acento, inserção e apagamento de sílabas ocorrem independentemente do encontro de sílabas fortes ou fracas (SANTOS, 2007: 127). Quanto à influência da fala adulta, a autora observa que as duas crianças produzem paroxítonos com menos freqüência do que na forma alvo, e afirma que o input não pode ser o responsável pela tendência iâmbica encontrada no PB. É proposta uma análise que se baseia no algoritmo de acentuação da língua-alvo, a saber, a de Lee (1995), que assume que o pé básico dos nomes no PB é o iambo, para explicar o porquê de uma tendência iâmbica nas primeiras palavras, que são predominantemente nomes ou verbos no infinitivo. A autora ainda traz contribuições para a teoria paramétrica ao propor que nem todos os parâmetros vêm com um valor default, pois se assim fosse, não haveria diferentes línguas apresentando tendências prosódicas iniciais divergentes. Santos propõe que o parâmetro de núcleo não tenha um valor inicial e que o parâmetro do pé tenha um valor binário, porém este não está disponível logo no início do processo de aquisição. Por essa razão, haveria um número considerável de produções monossilábicas iniciais e o número predominante de iambos ocorreria devido ao padrão prosódico da língua. 
Um outro estudo realizado por meio da análise de dados naturalísticos é o de Bonilha (2004), o qual analisa dados de uma criança (G.) entre 1;02 e 3;9 anos. Assim como Santos (2001), a autora observa que as produções infantis iniciais evidenciam a emergência tanto de pés trocaicos como de iâmbicos na aquisição fonológica. Neste estudo, não são encontrados dados com deslocamento de acento, os quais poderiam dar mais pistas a respeito de um suposto padrão prosódico preferencial. Todavia, no que se refere aos dados produzidos entre 1;2 e 1;4 anos, quando se observa o número de acerto, nota-se que o pé iâmbico é o mais produzido de acordo com a forma alvo, como é apresentado no quadro 1:

Faixa etária

Alvo Produção de acordo com o alvo

\begin{tabular}{|c|c|c|}
\hline $1 ; 1.22$ & Paroxítona leve & $87,7 \%(6$ de 7$)$ \\
& Oxítona leve & $\mathbf{1 0 0 \%}(\mathbf{1}$ de 1) \\
& Oxítona pesada & $\mathbf{1 0 0 \%}(\mathbf{1}$ de $\mathbf{1})$ \\
\hline $1 ; 3.10$ & Paroxítona leve & $72,7 \%(8$ de 11$)$ \\
& Oxítona leve & $\mathbf{1 0 0 \%}(\mathbf{3}$ de 3) \\
\hline $1 ; 3.24$ & Oxítona pesada & 0 \\
\hline & Paroxítona leve & $75 \%(6$ de 8$)$ \\
& Oxítona leve & $\mathbf{1 0 0 \%}(\mathbf{3}$ de 3) \\
& Oxítona pesada & 0 \\
\hline $1 ; 4.9$ & Paroxítona leve & $90 \%(9$ de 10$)$ \\
& Oxítona leve & $\mathbf{1 0 0 \%}(\mathbf{1}$ de $\mathbf{1})$ \\
& Oxítona pesada & $\mathbf{1 0 0 \%}(\mathbf{1}$ de $\mathbf{1})$ \\
\hline $1 ; 4.22$ & Paroxítona leve & $62,2 \%(9$ de 13$)$ \\
& Oxítona leve & $\mathbf{1 0 0 \%}(\mathbf{5}$ de 5) \\
\hline
\end{tabular}

Quadro 1: Produção prosódica de acordo com a forma alvo (Bonilha 2004)

Nota-se que, apesar de ter ocorrido mais produção de paroxítonas, as oxítonas foram as mais produzidas de acordo com a forma alvo.

Por último, o estudo de Baia (2006) que, após realizar um estudo sob a mesma perspectiva teórica de Santos $(2001,2007)$, encontra uma tendência iâmbica nos dados 
iniciais. A autora, após investigar o modelo prosódico predominante no léxico particular na aquisição (produções familiares, criações lexicais) e os erros de acento em dados produzidos por duas crianças entre 1;2 e 1;8 anos, nota, em seus resultados quantitativos, a falta de evidências a favor de uma tendência trocaica. Baia encontra uma tendência iâmbica no léxico inicial do PB; entretanto, não faz uma análise dos dados desconsiderando o léxico particular. Dessa maneira, a questão que ainda permanece é: será que a tendência iâmbica permaneceria se o léxico particular fosse desconsiderado? É o que é feito na análise desta pesquisa.

Sobre as diferentes metodologias e os resultados

Como foi visto, o estudo experimental de Rapp (1994) aponta uma tendência trocaica nos dados iniciais do PB, enquanto que estudos que lidam com dados naturalísticos assumem não haver uma tendência trocaica e/ou mostram indícios a favor de uma tendência iâmbica. Assim, a metodologia utilizada pode estar interferindo, e, por essa razão, nesta pesquisa, são conduzidos dois estudos, cada um feito com uma das metodologias, a fim de se tentar descobrir o que ocasiona tal discrepância. O próximo quadro resume o que foi exposto até o momento a respeito da tendência prosódica inicial encontrada por cada estudo: 


\begin{tabular}{|l|l|}
\hline Estudo Experimental - tendência & Estudo Observacional - tendência \\
\hline RAPP (1994) - trocaica (++) & SANTOS (2001) - iâmbica (+) \\
& BONILHA (2004) - iâmbica (+) \\
& SANTOS (2007) - iâmbica (++) \\
& BAIA (2006) - iâmbica $(++)$ \\
\hline
\end{tabular}

$(++)=$ indícios fortes $/(+)=$ indícios não tão fortes

Quadro 2: o modelo prosódico inicial no $P B$

Os estudos com indícios fortes (++) são os que, além de apontar um número considerável de iambos ou troqueus nos estágios iniciais, assumem um dos modelos como o inicial do PB.

\subsection{Há uma tendência prosódica universal?}

A seguir, é apresentado um quadro comparativo com todos os resultados encontrados ao longo desta pesquisa acerca do troqueu como modelo prosódico inicial em diferentes línguas. É importante ressaltar que nas línguas que tiveram mais de um trabalho sobre a tendência prosódica inicial, foi destacado o resultado que prevaleceu no maior número de estudos.

\begin{tabular}{|c|c|c|}
\cline { 2 - 3 } \multicolumn{1}{c|}{} & \multicolumn{2}{c|}{ Tendência Trocaica } \\
\hline Línguas & Sim & Não \\
\hline Línguas Germânicas & Inglês,Holandês e Alemão & --- \\
\hline Línguas Românicas & Catalão & Espanhol, PE, PB e Francês \\
\hline Línguas Semíticas & Hebraico & --- \\
\hline Línguas Maias & --- & Quiché (dialeto maia) \\
\hline Línguas Bantu & Sesoto ou Soto - Sul & --- \\
\hline \multicolumn{2}{|c|}{ Quadro 3: o modelo trocaico na aquisição } \\
\hline
\end{tabular}


O quadro 3 apresenta a tendência trocaica presente na aquisição em uma parte das línguas e ausente em outra. Percebe-se, também, que essa tendência está presente na aquisição de todas as línguas germânicas levantadas. Assim, pode-se sugerir que a solução de tal impasse seria afirmar que a tendência presente nos dados infantis é, simplesmente, um retrato da produção adulta (línguas germânicas trocaicas = produções infantis trocaicas). No intuito de se verificar essa possibilidade, o próximo quadro confronta a tendência prosódica presente na fala adulta com a que é encontrada nos dados infantis iniciais: 
$\begin{array}{lll}\text { Família Lingüística } & \text { Língua } & \text { Alvo } \\ & & \text { Criança }\end{array}$

\begin{tabular}{|c|c|c|c|}
\hline \multirow{4}{*}{ Germânicas } & Inglês & SW & SW \\
\cline { 2 - 4 } & Holandês & SW & SW \\
\cline { 2 - 4 } & Alemão & SW & SW \\
\hline \multirow{4}{*}{ Românicas } & PB & SW & WS \\
\cline { 2 - 4 } & PE & SW & WS \\
\cline { 2 - 4 } & Catalão & SW & SW, WS \\
\cline { 2 - 4 } & Espanhol & SW & WS \\
\cline { 2 - 4 } & Francês & WS & SW \\
\hline Semítica & Hebraico & WS & S \\
\hline Maia & Quiché & WS & SW \\
\hline Bantu & Sesoto & SW & . \\
\hline
\end{tabular}

Quadro 4: o modelo prosódico predominante na fala adulta e infantil

A correspondência entre modelo prosódico alvo e infantil não é encontrada na aquisição de todas as línguas, por exemplo, línguas como o português (PB e PE) e hebraico não apresentam tal correspondência. Logo o modelo prosódico inicial pode não ser uma simples reprodução do modelo que prevalece na forma alvo.

\footnotetext{
${ }^{12}$ As informações acerca do modelo prosódico predominante na forma alvo foram retiradas dos estudos citados. Porém, quando o estudo não trouxe tal informação, foi consultado o The World Atlas of Language Structures Online. Este atlas (http://wals.info/index) foi utilizado para o Catalão (ROCA, 1999) e Espanhol (ROCA, 1991).
} 


\section{HIPÓTESES}

Como foi apresentado nas seções anteriores, a maior parte dos estudos germânicos defende que o troqueu é o modelo prosódico default (ALLEN \& HAWKINS, 1980; GERKEN, 1994; ARCHIBALD, 1995; DEMUTH, 2006), e outros, apesar de citarem a predominância de troqueus, observam haver produção de erros direcionados para o iambo (KEHOE \& STOEL-GAMMON, 199; VIHMAN et al., 1998). No que se refere às línguas românicas, a tendência trocaica não é encontrada por todos os estudos. O estudo sobre o catalão afirma ser o troqueu o modelo prosódico inicial (PRIETO, 2005), enquanto que o estudo sobre o espanhol (HOCHBERG, 1988) defende um início neutro, i.e. sem nenhuma tendência prosódica predominante. Os estudos sobre o PB, particularmente, apresentam um quadro mais complexo, no qual os estudos naturalísticos apontam indícios a favor de uma tendência iâmbica (SANTOS, 2001, 2006, 2007; BAIA, 2006) e o experimental defende uma tendência trocaica inicial (RAPP, 1994). Como foi discutido nas seções 1 e 2, a metodologia parece interferir e, especialmente, o tipo de léxico contemplado em cada análise, i.e., os estudos naturalísticos analisam dados no seu total (léxico comum e léxico particular), enquanto que o experimental lida apenas com léxico comum. Um outro fator que parece interferir é a classe gramatical contemplada na análise de cada tipo de estudo, pois o experimental lida apenas com nomes e o observacional com nomes e verbos.

Sobre as diferentes tendências prosódicas atestadas em estudos sobre diferentes línguas (trocaica versus iâmbica), tem-se a proposta de Santos (2007) que vai assumir que o padrão inicial é resultado da marcação de parâmetros relacionados ao pé (a extensão: binária) e o núcleo (não-marcado) da língua-alvo, proposta que é vantajosa sobre as demais, pois apresenta uma explicação unificada para dois fatores apontados na literatura: crianças 
que adquirem o PB começam com uma tendência iâmbica e as que adquirem o inglês uma tendência trocaica. Tendo este quadro, as hipóteses a serem perseguidas no decorrer da análise nos próximos capítulos são:

1. Dado que os estudos naturalísticos afirmam uma tendência iâmbica e o experimental uma tendência trocaica no PB, uma hipótese a ser perseguida é a de que o método utilizado pode interferir nos resultados.

2. Dado que o léxico particular desempenha um papel importante na tendência iâmbica encontrada pelos estudos observacionais, a hipótese a ser perseguida é de que a ausência dele, nos dados naturalísticos, faz com que os demais dados apontem a mesma tendência encontrada pelo experimental (trocaica).

3. Uma hipótese alternativa é a de que não apenas o tipo de léxico (particular ou comum) interfira nos resultados, mas a classe gramatical contemplada em cada método, pois o experimental conduzido por Rapp (1994) e o realizado nesta pesquisa lidam apenas com nomes, enquanto que o observacional lida com nomes e verbos. 


\section{DADOS EXPERIMENTAIS (DEX)}

A forma de notação usada segue o que os estudos aquisicionistas, em geral, têm feito até o presente momento. São analisados os seguintes modelos prosódicos que aparecem na análise tanto de DEX (dados experimentais) quanto de DES (dados espontâneos):

SW (troqueu)

WS (iambo)

SWW

WSW

WWS

\subsection{Metodologia}

Os dados desta pesquisa são dados experimentais de produção, coletados nos seguintes lugares:

1) Creche Maria de Nazaré (SP) / setembro - dezembro de 2006.

2) Creche Municipal Alcides Cunha (Ferraz de Vasconcelos) / março - abril de 2007.

3) Residência de duas crianças / setembro de 2006 
O experimento foi realizado por meio de nomeação de figuras, assim como Rapp (1994) fez; porém as figuras foram apresentadas dias antes para todas as crianças em teatro de fantoches. Dessa maneira, foi possível fazer com que as crianças ficassem familiarizadas com todas as figuras e com a experimentadora antes do experimento. Quanto aos experimentos rodados em duas residências, a experimentadora visitou as crianças dias antes para interagir e apresentar as figuras por meio de teatro de fantoches. Nas creches, no início, foram selecionadas, por meio de observação da experimentadora e indicação das educadoras, 62 crianças, entretanto, apenas 42 crianças participaram do experimento. As crianças que não participaram dos experimentos não participaram devido às seguintes causas: 1) não interagiram com o experimentador nas duas tentativas; 2) o responsável não autorizou; 3) faltaram no dia do experimento. No final, participaram do experimento 42 crianças entre $1 ; 5$ - 3;0 anos (20 meninas e 22 meninos), todas monolíngües que adquirem o PB como língua materna. Além disso, cabe ressaltar que todas as crianças que participaram do experimento têm a mesma condição sócio-econômica (classe média baixa).

O experimento é de produção e a tarefa de elicitação. Como algumas crianças na faixa etária de 1;5 - 1;8 anos apresentaram algumas dificuldades em reconhecer todas as figuras que lhe eram mostradas, e o léxico precisava ser testado, foi utilizada a estratégia da imitação quando necessária. No entanto, tal estratégia foi usada raras vezes (apenas com quatro crianças de 4 a 8 vezes), e a palavra não foi dita isoladamente, pois oscilou entre início de enunciado (i.e. 'carro bonito mesmo'), meio (i.e. 'mas que carro bonito'), e final (i.e. 'olha que carro!'). As produções das crianças diferenciaram-se do alvo, pois mesmo com as pistas, no final, a produção delas para a palavra carro, por exemplo, foi ‘bibi’ (1;5 P.C) ou recorte de sílaba tônica como em 'ka' (1;7 - P.M). De um total de 1565 tokens, 
foram produzidas apenas $102(6,5 \%)$ palavras por imitação, o que não é significativo estatisticamente para poder interferir nos dados.

\subsubsection{Seleção do léxico a ser testado}

Foi selecionado um número de dissílabos iâmbicos (10) equivalente ao de dissílabos trocaicos (10). No que se refere aos trissílabos, constam no experimento três tipos (SWW, WSW, WWS) e foram selecionadas 6 palavras de cada tipo. Foi utilizado o mesmo número de troqueus e iambos no experimento para que não houvesse predominância nos resultados devido a alguma discrepância na forma alvo apresentada; isto é, poderia haver um suposto resultado que favorecesse o pé trocaico por causa do maior número de palavras trocaicas utilizadas no experimento. Por exemplo, Rapp (1994) utiliza 49 itens lexicais no seu experimento ( $43 \%$ troqueus; $36,7 \%$ iambos e $20,3 \%$ dátilos) e encontra a predominância de troqueus. Porém, houve um maior número de troqueus $(43 \%)$ e isso talvez tenha contribuído para a predominância trocaica encontrada pela autora.

Nesta pesquisa, é desconsiderado o fato de a criança, na faixa etária investigada, ainda não ter adquirido alguns fonemas e alofones. Isso porque o que interessa, neste estudo, é o modelo prosódico presente na produção da criança, e é assumido que a comutação de algum segmento não interfira na produção prosódica. Dessa maneira, foram inseridas, no inventário lexical do experimento, palavras que contêm, por exemplo, tepe alveolar ('varal') ${ }^{13}$. A relação das palavras utilizadas está no próximo quadro:

\footnotetext{
${ }^{13}$ Tal assunção pode ser alvo de pesquisas futuras.
} 


\begin{tabular}{|l|l|}
\hline SW & carro, lápis, bola, copo, prato, ovo, chave, calça, uva, gato \\
\hline WS & fogão, boné, café, sofá, maçã, anel, bombom, balão, sabão, varal \\
\hline WSW & estrela, boneca, girafa, cachorro, dinheiro, sapato \\
\hline WWS & violão, jacaré, bambolê, caminhão, avião, macarrão \\
\hline SWW & mágico, fósforo, ônibus, lâmpada, árvore, óculos \\
\hline
\end{tabular}

Quadro 1: Palavras utilizadas no experimento

Neste estudo experimental, são focalizados os nomes para comparação com o outro trabalho experimental (RAPP, 1994). A distribuição prosódica das palavras foi então:
SW - 10 palavras
WS - 10 palavras
SWW - 6 palavras (recorte provável de SW (6)
WSW - 6 palavras( recorte tanto de SW (6) ou WS (6)
WWS - 6 palavras (recorte provável de WS (6)

Dessa maneira, tem-se a possibilidade de 44 produções dissilábicas, sendo $22 \mathrm{SW}$ $(10+6+6)$ e 22 WS $(10+6+6)$, ou seja, $50 \%$ de possibilidade para a produção de cada modelo.

A transcrição dos dados foi realizada auditivamente utilizando o alfabeto fonético internacional (IPA), e as transcrições realizadas pela experimentadora (100\%) foram confrontadas com a transcrição de outro fonólogo ${ }^{15}$. Na comparação das transcrições, houve 97\% de concordância, o que indica que os dados foram corretamente transcritos pela autora deste trabalho. A respeito dos 3\% discordantes, após discussão entre os dois fonólogos, chegou-se a um acordo sobre a produção.

\footnotetext{
${ }^{14}$ As palavras em negrito são as que foram usadas por Rapp (1994) também.

${ }^{15}$ Agradeço a Daniel Oliveira Peres pela ajuda.
} 


\subsubsection{Descrição do experimento}

Para a elaboração do experimento, foram utilizados os seguintes materiais: cartolinas com desenhos, gravador digital e dois fantoches (cf. figuras 1 e 2). Os fantoches foram utilizados tanto no experimento como nas interações iniciais entre experimentadora e as crianças. No início de cada sessão, os dois bonecos apresentavam-se para a criança e esta poderia escolher com quem falar.

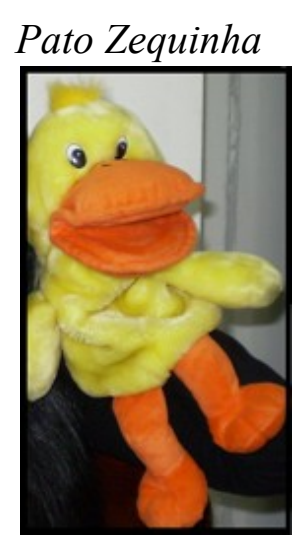

Figura 1

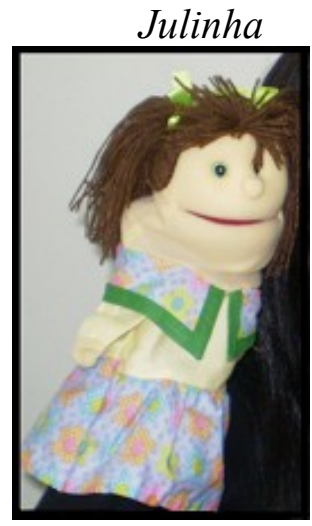

Figura 2

O experimento ocorreu na seguinte seqüência: o fantoche Zequinha (ou o fantoche Julinha) pedia a ajuda da criança para lembrar o nome do que aparecia na cartolina ${ }^{16}$ porque ele (ela) era um menino(a) bem atrapalhado(a) que, apesar de já ter brincado com ela (a criança) e as figuras, tinha esquecido o nome de tudo. Quando as crianças não lembravam o nome do que estava no desenho, a experimentadora, que modulava a voz do fantoche, dava pistas para a criança relacionadas com as características de cada desenho. É importante ressaltar que as palavras não eram representadas em um só desenho, isto é, estavam

\footnotetext{
${ }^{16}$ Ver desenhos no Anexo 1.
} 
inseridas em um contexto maior, por exemplo, para que a criança falasse a palavra "carro" a experimentadora perguntava: “a fumaça está saindo do quê?" (mostrando o desenho de um carro andando e soltando fumaça).

\subsection{Resultados}

A tabela 1 mostra a quantidade de dados esperada e a produzida para cada modelo prosódico:

Modelo

\begin{tabular}{|c|c|c|}
\hline SW & (42 crianças / 10 figuras) & 562 \\
\hline WS & (42 crianças / 10 figuras) & 407 \\
\hline SWW & (42 crianças / 6 figuras) & 84 \\
\hline WSW & (42 crianças / 6 figuras) & 169 \\
\hline WWS & 252 (42 crianças / 6 figuras) & 121 \\
\hline $\mathrm{M}^{18}$ & Ausente no estímulo & 222 \\
\hline Total & 1596 & 1565 \\
\hline
\end{tabular}

Tabela 1: total de produções esperadas e produzidas

\section{Expectativa $\quad$ Produção $^{17}$}

A tabela 2 apresenta os resultados gerais de todos os modelos prosódicos produzidos de 1;5 a 3;0 anos pelas 42 crianças em 1520 dados. ${ }^{19} \mathrm{Na}$ primeira coluna, tem-se o modelo prosódico e a forma como foi produzido, por exemplo, $\mathrm{SW}>\mathrm{M}$ significa que o modelo prosódico SW foi produzido como monossílabo. Cabe ressaltar que a produção não é necessariamente a das mesmas palavras esperadas. Por exemplo, em 'ônibus' o esperado é a produção SWW, mas muitas crianças produziram SW. Além disso, 31 palavras não

\footnotetext{
${ }^{17}$ As palavras transcritas estão no anexo 2.

${ }^{18} \mathrm{M}$ significa monossílabo (tônico ou átono).

${ }^{19}$ DEX tem no total 1565 dados, porém não foram contados os dados de erro de acento (27) e léxico particular (18 criações lexicais) neste primeiro momento. Estes são analisados separadamente.
} 
foram contadas na análise dos dados pelas seguintes causas: 1) algumas crianças deixaram de produzir ou 2) devido à fala muito baixa da criança, não puderam ser ouvidas para a transcrição.

\begin{tabular}{|c|c|c|c|c|c|c|}
\hline Alvo & Produção & Média & Desvio Padrão & Mínimo & Mediana & Máximo \\
\hline \multirow[t]{2}{*}{$\mathbf{S W}$} & M & 0,88 & 1,81 & 0,00 & 0,00 & 7,00 \\
\hline & SW & 9,12 & 1,81 & 3,00 & 0,00 & 10,00 \\
\hline \multirow[t]{2}{*}{$\overline{W S}$} & $\mathbf{M}$ & 3,14 & 3,18 & 0,00 & 2,00 & 10,00 \\
\hline & $\mathbf{W S}$ & 6,85 & 3,18 & 0,00 & 8,00 & 10,00 \\
\hline \multirow[t]{3}{*}{ SWW } & $\mathbf{M}$ & 0,50 & 1,35 & 0,00 & 0,00 & 6,00 \\
\hline & SW & 3,40 & 1,62 & 0,00 & 3,00 & 6,00 \\
\hline & SWW & 2,02 & 1,61 & 0,00 & 2,00 & 5,00 \\
\hline \multirow[t]{4}{*}{ WSW } & M & 0,33 & 1,05 & 0,00 & 0,00 & 4,00 \\
\hline & SW & 1,59 & 1,88 & 0,00 & 1,00 & 6,00 \\
\hline & WS & 0,11 & 0,33 & 0,00 & 0,00 & 1,00 \\
\hline & WSW & 3,85 & 2,25 & 0,00 & 5,00 & 6,00 \\
\hline \multirow[t]{3}{*}{ WWS } & M & 0,76 & 1,49 & 0,00 & 0,00 & 6,00 \\
\hline & $\mathbf{W S}$ & 2,26 & 1,88 & 0,00 & 2,00 & 6,00 \\
\hline & WWS & 2,71 & 2,36 & 0,00 & 2,50 & 6,00 \\
\hline
\end{tabular}

Tabela 2: dados descritivos de DEX $X^{20}$

Os dados da tabela 2 serão retomados e discutidos ao longo da análise. Pode-se adiantar que, nesses dados, a maior média de produção ocorreu na produção de SW quando o alvo era SW $(\bar{x}=9,12)$, mostrando predominância de troqueus. Essa tendência foi seguida pela produção de WS quando o alvo era WS $(\overline{\mathrm{x}}=6,9)$.

${ }^{20}$ Média: Qualquer distribuição em torno da qual equilibram as discrepâncias.

$\overline{\mathbf{x}}=\sum \mathbf{x} \quad \overline{\mathrm{x}}=$ média $/ \sum=$ soma/ $\mathrm{x}=$ total de produções de determinado modelo prosódico/ $\mathrm{N}$ : total N de crianças participantes no experimento (42).

Desvio padrão: Variabilidade média de uma distribuição, já que ele mede a média de discrepâncias (desvios) com relação a $\bar{X}$. Dessa maneira, quanto maior a variabilidade em torno da média de uma distribuição, maior o desvio padrão.

Mediana (md): o ponto central da distribuição que se divide em duas partes (50\% acima e $50 \%$ abaixo). $\underline{\mathbf{N}+1} \mathrm{~N}=$ total de produções de um determinado modelo. (LEVIN, 1987). 
Para a obtenção dos resultados presentes na tabela 2 , foram considerados os dados na sua totalidade, isto é, dados das 42 crianças em um período de 1;5 a 3;0 anos (desconsiderando os dados de erro de acento e léxico particular). Dessa maneira, para uma análise mais detalhada sobre o que ocorre com cada modelo prosódico ao longo do período aqui analisado, foi preciso estabelecer algumas subdivisões de faixas etárias. Ressalta-se que estas subdivisões não estão, necessariamente, relacionadas com estágios de aquisição prosódica $^{21}$, a saber, estágios de aquisição do acento, os quais pediriam mais repartições e fogem do escopo desta pesquisa. Dessa maneira, são considerados três intervalos na análise: $^{22}$

Faixa etária 1 (Fx1): $1 ; 5-2 ; 0$ anos

Faixa etária 2 (Fx2) : 2;1 - 2;6 anos

Faixa etária 3 (Fx3): $2 ; 7-3 ; 0$ anos

Destaca-se que a faixa etária 1 é adequada para comparação entre os resultados desta pesquisa e de outras que verificam o modelo prosódico inicial, pois a maior parte dos estudos analisa uma faixa etária que se estende até 2;0 anos (ALLEN \& HAWKINS, 1980; GERKEN, 1994; RAPP, 1994; DEMUTH, 1996, VIHMAN et al., 1998; BAIA, 2006; SANTOS, 2007; entre outros).

Os demais intervalos foram criados arbitrariamente no intuito de uniformizar a análise dos dados. Para verificar se estes intervalos criados apresentariam significância e

\footnotetext{
${ }^{21}$ Para propostas de estágios de aquisição prosódica do PB, conferir Santos $(2001,2007)$ e Bonilha (2004).

${ }^{22}$ Levin (1987) ressalta que sobre a determinação do número de intervalos, em suma, o pesquisador geralmente toma sua decisão quanto ao número de intervalos baseado em seu próprio conjunto de dados e em seus objetivos, fatores que podem variar consideravelmente de uma situação de pesquisa para outra.
} 
interação entre faixa etária e modelo prosódico, foi aplicado um teste (ANOVA), cujos resultados são apresentados na tabela 3:

\begin{tabular}{|l|r|r|r|r|}
\hline Origem & Numerador & Denominador & \multicolumn{1}{c|}{ Fo } & Valor-P \\
\hline Faixa & 2 & 39 &, 660 &, 523 \\
\hline Modelo & 5 & 195,000 & 196,057 &, 000 \\
\hline Faixa * Modelo & 10 & 195,000 & 15,996 &, 000 \\
\hline
\end{tabular}

Tabela 3: ANOVA - interação entre grupo de faixa etária e modelo prosódico

Como pode ser observado, a linha 3 da tabela 3 (Faixa * Modelo) mostra efeito de interação entre faixa etária criada e modelo prosódico (Valor-P $<0.05$ ), o que demonstra que cada intervalo apresenta comportamento diferenciado no que se refere a esses dois fatores (faixa e modelo). Dessa maneira, espera-se que de acordo com a faixa, a produção prosódica diferencie-se. Por essa razão, os três intervalos são mantidos.

Justificadas as faixas, o próximo passo é mostrar os resultados e análise de DEX no que se refere à produção prosódica. Lembrando que em DEX são analisados apenas dados de nomes, da mesma forma que Rapp (1994) fez no seu estudo experimental.

\subsubsection{Produções pelo tamanho da palavra}

Quanto ao tamanho da palavra, assim como Rapp observa (1994), os dissílabos predominam no total de dados. Observe os resultados:

Tabela 4: O tamanho da palavra em DEX

\begin{tabular}{|l|c|c|c|c|}
\hline & Monossílabos & Dissílabos & Trissílabos & Total \\
\hline Fx1 & $154(69,3 \%)$ & $\mathbf{3 1 1}(\mathbf{3 2 , 1 \%})$ & $41(11 \%)$ & $506(32,3 \%)$ \\
\hline Fx2 & $59(26,6 \%)$ & $\mathbf{3 1 0}(\mathbf{3 1 , 9 \% )}$ & $97(25,9 \%)$ & $466(29,8 \%)$ \\
\hline Fx3 & $9(4,1 \%)$ & $\mathbf{3 4 8 ( 3 6 \% )}$ & $236(63,10 \%)$ & $593(37,9 \%)$ \\
\hline Total & $222(100 \%)$ & $\mathbf{9 6 9 ( 1 0 0 \% )}$ & $374(100 \%)$ & $1565(100 \%)$ \\
\hline
\end{tabular}




\subsubsection{Produções monossilábicas}

Em todo o período analisado, foram encontradas 222 produções monossilábicas ocorridas após apagamento em alvo SW, WS, SWW, WSW, WWS. A sílaba tônica (S) permaneceu em 91,8\% (204) dos casos, enquanto que em apenas $8,2 \%$ (18) dos casos a sílaba átona $(\mathrm{W})$ foi a que permaneceu:

$\mathbf{S}$

$\begin{array}{lll}(01)[\mathrm{ka}] & \text { “carro" } & (\mathrm{P} . \mathrm{C} / 1 ; 5) \\ (02)[\mathrm{n} \varepsilon] & \text { "boné" } & (\mathrm{J} . \mathrm{P} / 1 ; 8) \\ (03)[\mathrm{fo}] & \text { "fósforo" } & (\mathrm{L} . \mathrm{G} / 1 ; 5) \\ (04)[\mathrm{pa}] & \text { “sapato" } & (\mathrm{P} . \mathrm{M} / 1 ; 7)\end{array}$

W

$\begin{array}{lll}\text { (05) [pi] } & \text { "lápis" } & \text { (P.M/1;7) } \\ \text { (06) [va] } & \text { "uva" } & (\mathrm{I} . \mathrm{S} / 2 ; 1)\end{array}$

Como foi mostrado na tabela 2 da seção 4.2, o modelo prosódico alvo que sofreu mais apagamento e foi produzido como monossílabo, considerando os dados das três faixas conjuntos, foi o WS $(\bar{x}=3,14)$. O gráfico 1 mostra qual o modelo prosódico foi mais alvo de apagamento em cada faixa etária aqui considerada: 


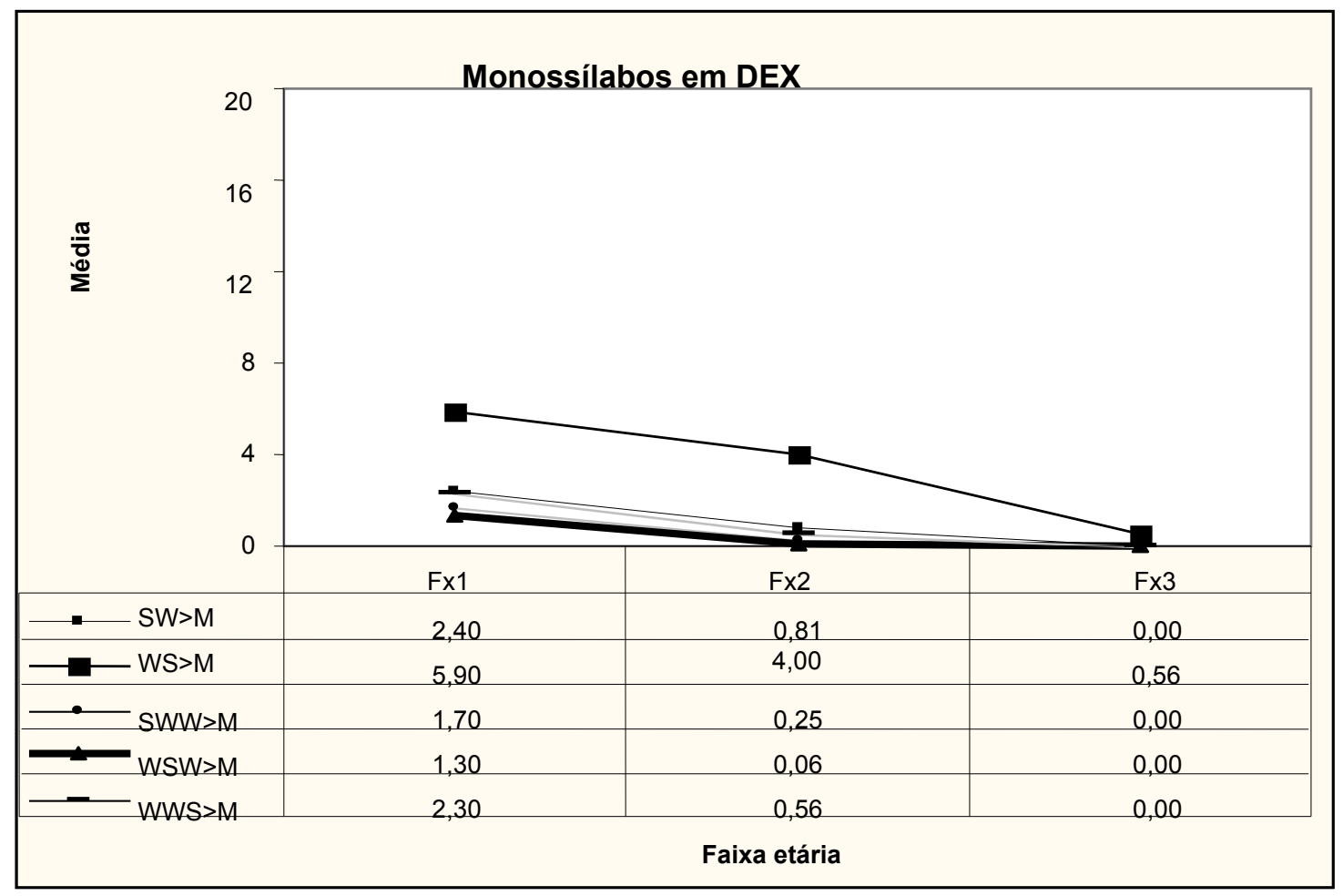

Gráfico 1: monossilabos em DEX

Observa-se que o processo de apagamento que favorece a produção monossilábica decresce ao longo das faixas e que o modelo WS foi mais alvo de produções monossilábicas. Curiosamente, como foi visto no capítulo do quadro teórico, o processo de apagamento em oxítonos, que favorece a produção de monossílabos na aquisição, é freqüente em línguas de acento final, como em quiché (DEMUTH, 1996), francês (DEMUTH, 2003) e hebraico (ADAM \& BAT-EL, 2007).

\subsubsection{Produções dissilábicas}


Como foi mostrado na tabela 2 da seção 4.2 , considerando os dados das três faixas somados, o modelo SW foi o mais produzido de acordo com a sua forma alvo ( $\mathrm{SW}>\mathrm{SW}, \overline{\mathrm{x}}=$ 9,12). O modelo WS por ser mais alvo de apagamento, teve um número menor de produções dissilábicas $(\bar{x}=6,9)$. Porém, após o teste de qui-quadrado de aderência ${ }^{23}$, constatou-se que as médias de SW e WS, apesar de SW ter prevalecido aparentemente, não são significativamente diferentes (Valor-P $>0,05){ }^{24}$

No que se refere aos trissílabos, quando SWW sofreu apagamento que resultasse em dissílabo, o modelo SW foi o que se sobressaiu $(\overline{\mathrm{x}}=3,40)$. O modelo WSW sofreu mais apagamento que resultasse $\mathrm{SW}(\overline{\mathrm{x}}=1,59)$ do que WS $(\overline{\mathrm{x}}=0,11)$ - as médias não são estatisticamente diferentes (Valor-P > 0,05) - , enquanto que o modelo WWS sofreu mais apagamento que favorecesse WS $(\overline{\mathrm{x}}=2,26)$.

O gráfico 2 mostra o total de produção de dissílabos (de acordo com a forma alvo ou após apagamento em trissílabos) em cada faixa:

\footnotetext{
${ }^{23}$ Qui-Quadrado $\left(\chi^{2}\right)$ é um teste de hipóteses que se destina a encontrar um valor da dispersão para duas variáveis nominais, avaliando a associação existente entre variáveis. O princípio básico deste método é comparar proporções, isto é, as possíveis divergências entre as freqüências observadas e as, hipoteticamente, esperadas para um certo evento. Normalmente, em Lingüística, para determinar o nível de significância é fixada a probabilidade de erro de Valor-P $<0,05$ (GÓMEZ, 2002).

${ }^{24}$ Neste primeiro momento, são comparadas as médias no teste qui-quadrado. Por causa da rigidez desse teste ao testar a aleatoriedade das médias, no final deste capítulo é realizado o Teste-F com os valores absolutos, no intuito de verificar se este teste pode apontar um modelo prosódico predominante.
} 


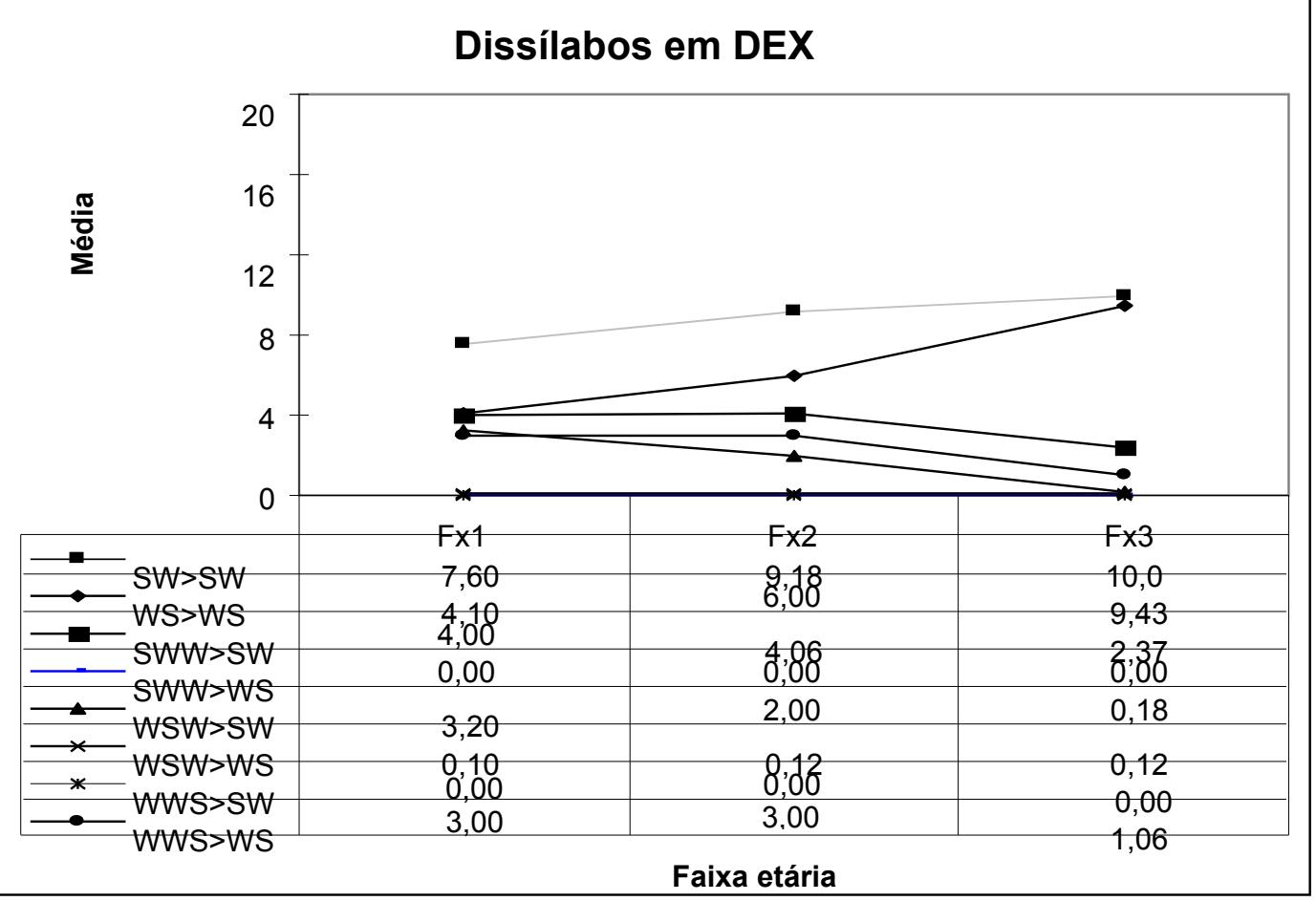

Gráfico 2: produções dissilábicas em DEX

Observa-se que o dissílabo mais produzido nas três faixas etárias é o SW quando o alvo é SW, SWW e WSW. Quanto ao modelo WS, quando produzido de acordo com o alvo WS, o seu número de produções é inferior ao de SW em Fx1 e Fx2, mas a partir de Fx3 ele passa a ser produzido com uma freqüência semelhante a de SW. O modelo WS predominou quando o modelo WWS foi alvo de apagamento. O trissílabo WSW, quando sofreu apagamento, foi produzido, majoritariamente, como SW $(\mathrm{Fx} 1 \overline{\mathrm{x}}=3,20, \mathrm{Fx} 2 \overline{\mathrm{x}}=2,00, \mathrm{Fx} 3 \overline{\mathrm{x}}=$ 0,18), em oposição a WS (Fx1 $\bar{x}=0,10, F x 2 \bar{x}=0,12, F x 3 \bar{x}=0,12)$. Em seguida, são apresentados exemplos dessas produções dissilábicas: 
$\mathbf{S W}>\mathbf{S W}$

$\begin{array}{lll}(07) \text { ['ka.v] } & \text { 'carro' } & (\mathrm{G} . \mathrm{A} / 1 ; 8) \\ (08)[\text { 'ko.pu] } & \text { 'copo' } & (\text { A.F } / 1 ; 10) \\ (09)[\text { 'ta.vI] } & \text { 'chave' } & (\text { A.J } / 2 ; 0)\end{array}$

WS $>$ WS

$\begin{array}{lll}\text { (10) [fo.'kãw] } & \text { 'fogão' } & \text { (G.V/2;0) } \\ \text { (11) [so.'fa] } & \text { 'sofá' } & \text { (P.S/2;5) } \\ \text { (12) } \text { [ma.'sã] } & \text { 'maçã' } & \text { (G.F/2;6) }\end{array}$

SWW $>$ SW

$\begin{array}{lll}\text { (13) ['o.kU] } & \text { 'óculos’ } & (\mathrm{T} . \mathrm{S} / 1 ; 6) \\ \text { (14) ['a.vI] } & \text { 'árvore’ } & \text { (J.P/1;8) }\end{array}$

WSW $>$ SW
(15) [' $\varepsilon . \mathrm{ke}]$
'boneca'
(E.S/1;8)
(16) ['te.le]
'estrela'
(C.M/ 2;1)

WSW > WS

$\begin{array}{lll}\text { (17) }[\text { i.'a] } & \text { 'girafa' } & \text { (P.M/1;7) } \\ \text { (18) }[\text { e.'te] } & \text { 'estrela' } & \text { (L.G/1;9) }\end{array}$

WWS > WS
(19) [bo.'le]
'bambolê'
(A.F/1;10)
(20) [ka.' $\varepsilon$ ]
'jacaré'
(J.H/1;11) 
Como foi mostrado com os resultados presentes no gráfico 2, a produção de SW se sobressaiu nas três faixas etárias quando o alvo era SW, SWW ou WSW, porém, após o teste de qui-quadrado de aderência, constatou-se que em nenhuma das faixas etárias o total de produção de SW e WS foi significativamente diferente (Valor-P > 0,05).

\subsubsection{Produções trissilábicas}

Como apontado na tabela 2 da seção 4.2, o modelo mais produzido foi o WSW ( $\bar{x}=$ 3,85), seguido por WWS ( $\bar{x}=2,71)$ e $\operatorname{SWW}(\bar{x}=2,02)$. O gráfico 3 mostra o total de produção de trissílabos ao longo das faixas etárias:

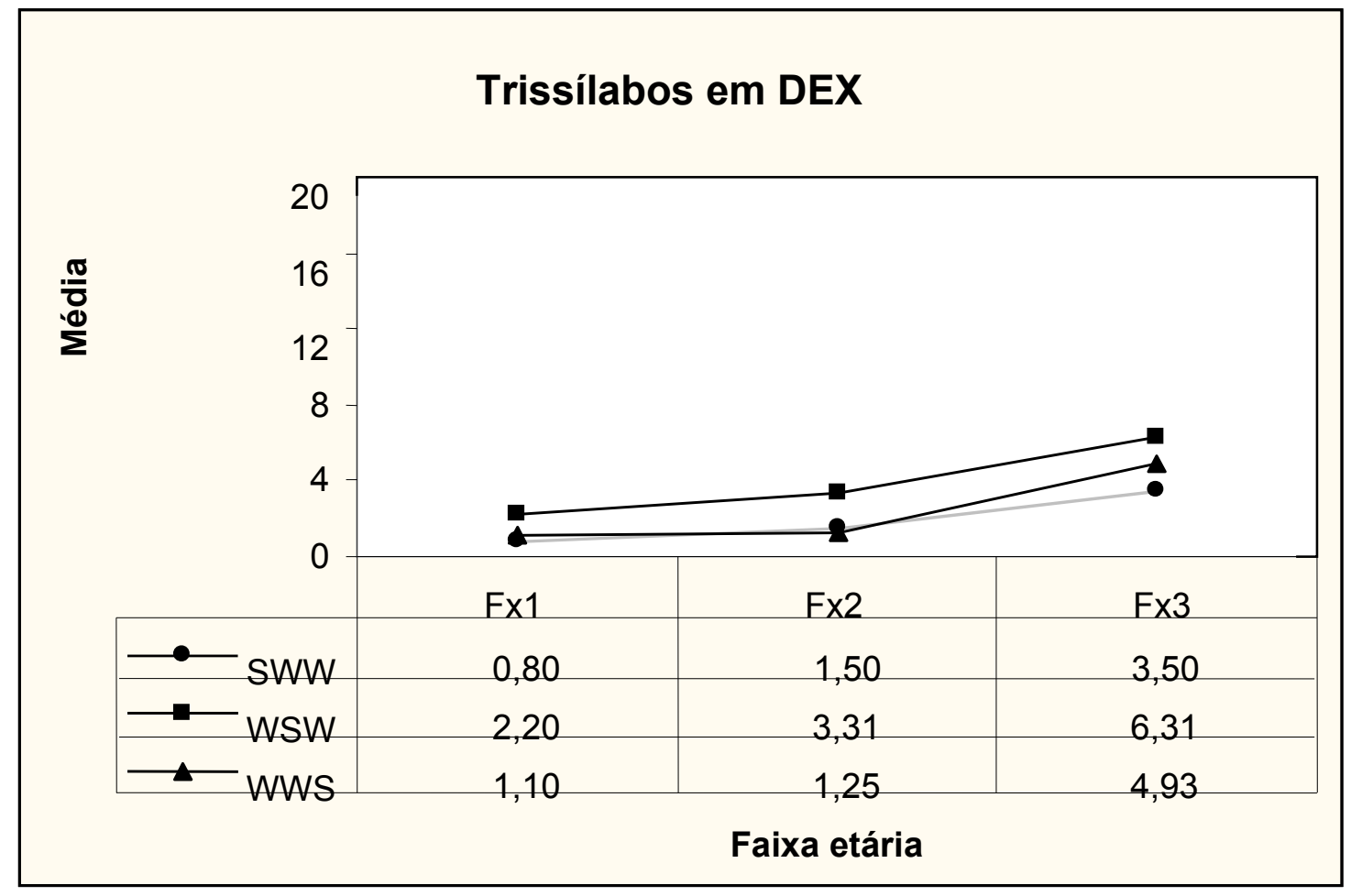

Gráfico 3: produções trissilábicas em DEX 
Como o gráfico 3 mostra, a produção trissilábica aumenta a partir de Fx3, quando os apagamentos em trissílabos favorecendo a produção de monossílabos e dissílabos deixam de ser freqüentes. O trissílabo mais produzido nas três faixas é o WSW.

A seguir são apresentados exemplos de produções trissilábicas:

\section{SWW $>$ SWW}
(21) ["ma.3i.kv]
'mágico'
(M.L/2;2)
(22) ['a.go.le]
'árvore'
(G.F/2;6)

WSW $>$ WSW
(23) [ba.'e.ke]'boneca'
(C.M/2;1)
(24) [ka.'t $\mathrm{t}$ o.v]
'cachorro'
(G.F/2,6)

\section{WWS $>$ WWS}
(25) [ka.mi.'jãw]
'caminhão'
(P.S/2;5)
(26) [ma.ka.'xãw]
'macarrão'
(J.O/2,7)

\subsubsection{Deslocamento de acento}

Como apontado na seção 2.3, os erros de acento presentes nos dados de Rapp (1994) tenderam a favorecer o iambo. O mesmo é encontrado no estudo de Baia (2006) e de Santos $(2006,2007)$ sobre a aquisição do PB, e, curiosamente, no estudo de Kehoe \& StoelGammon (1997) sobre a aquisição do inglês e no de Taelman (2004) sobre o holandês. 
Em DEX, houve 27 casos de erros de acento (1,72\% do total de dados), uma quantidade bem pequena que não é significativa estatisticamente, e, por essa razão, os dados com deslocamento de acento não podem desempenhar um papel importante em uma suposta tendência prosódica inicial do PB. No entanto, esses dados não deixam de ser apresentados devido ao seu direcionamento para um modelo prosódico específico.

Todos os deslocamentos de acento ocorridos favoreceram a produção de iambos, isto é, não houve iambo produzido como troqueu, mas apenas troqueu produzido como iambo. Além disso, os erros ocorreram, majoritariamente, em dissílabos. No que se refere aos trissílabos, o alvo SWW foi o único modelo trissilábico que teve deslocamento de acento quando as crianças tentavam produzi-lo (4 casos de SWW $>$ WSW e 1 caso de SWW $>$ WWS). O gráfico 4 mostra a porcentagem ${ }^{25}$ referente a cada modelo prosódico produzido com deslocamento de acento:

\footnotetext{
${ }^{25}$ Não foi realizado o cálculo da média aritmética devido ao número pequeno de produções com deslocamento de acento e por esse tipo de produção não ter ocorrido na produção de todas as 42 crianças.
} 


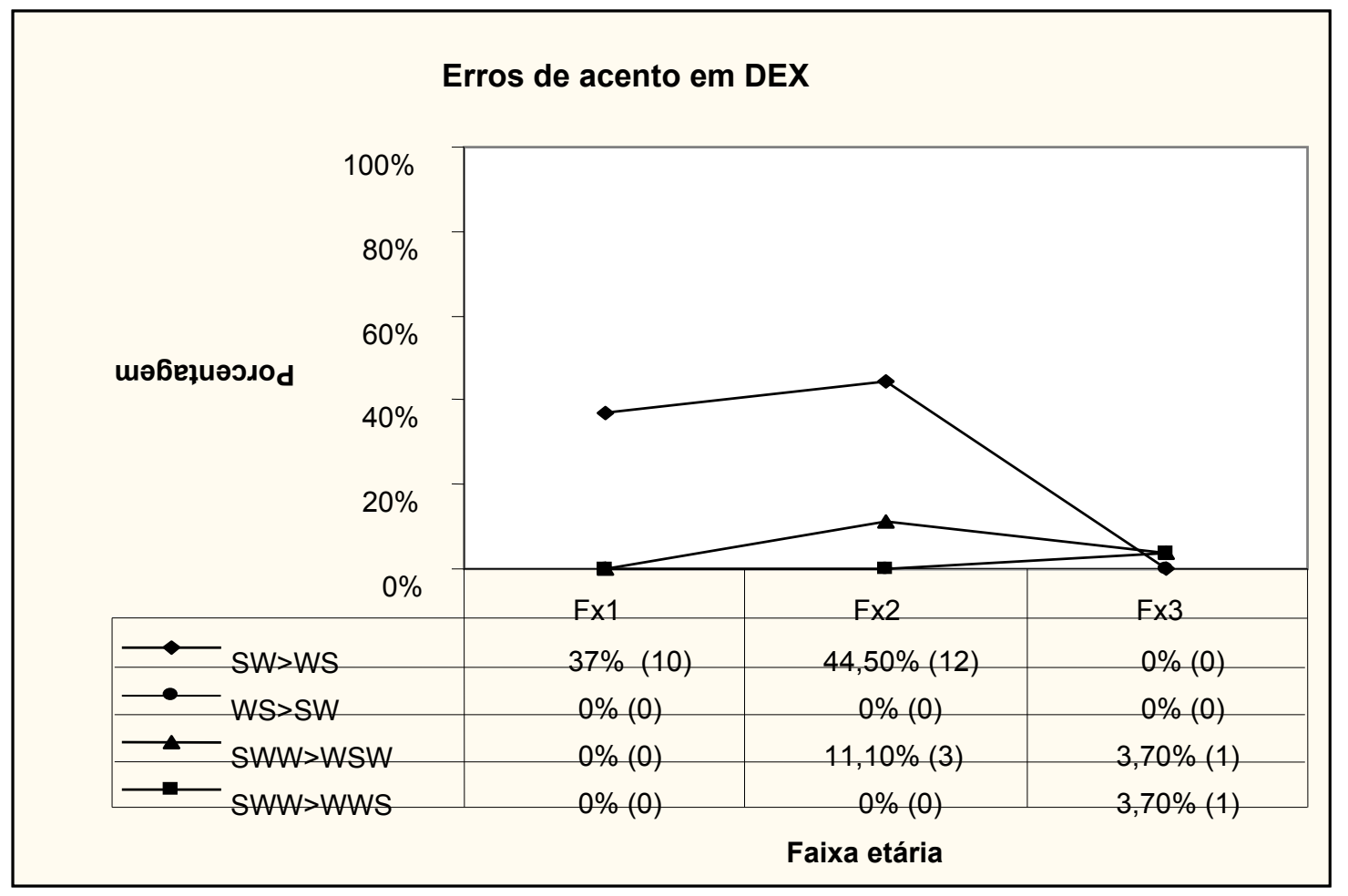

Gráfico 4: erros de acento em $D E X$

Como gráfico 4 mostra, os erros de acento são mais freqüentes em Fx1 e Fx2, e quando o modelo prosódico era dissilábico, prevaleceu o deslocamento de acento favorecendo WS. Em Fx1 não foram encontrados deslocamentos de acento em trissílabos devido ao apagamento neste tipo de alvo que favorece a produção de monossílabos e dissílabos. A partir do Fx2, são encontrados deslocamentos de acento neste tipo de modelo, e em todos os casos o acento foi deslocado no alvo SWW.

Exemplos de erros de acento SW > WS:
(27)
[u.'va]
'uva'
(J.P/ $1 ; 8)$
(28) [o.'va]
'ovo'
(C.M/ 2;1) 
Exemplos de deslocamento de acento no alvo SWW:

(29) [lã.'pa.de] 'lâmpada' (A.J/ 2;0)

(30) [o.ni.'bo] 'ônibus' (P.H/2;11)

Dessa maneira, observa-se que os erros de acento favorecem a produção de iambos, o que difere da tendência encontrada nos dados gerais (trocaica), mas que vai ao encontro da tendência encontrada nos erros de acento na aquisição do inglês (KEHOE \& STOELGAMMON, 1997) e holandês (TAELMAN, 2004).

\subsubsection{Léxico particular}

Pelo estudo ter sido controlado e pelo inventário lexical conter apenas o léxico comum, não ocorreram casos de produções familiares, apenas alguns casos de criações lexicais. Em DEX, houve 18 casos de criações lexicais (1,15\% do total de dados); quantidade, assim como a quantidade de dados de erro de acento, bem pequena. Como o gráfico 5 apresenta, a maior parte das produções foi composta por dissílabos e houve apenas criação lexical trissilábica do modelo WSW: 


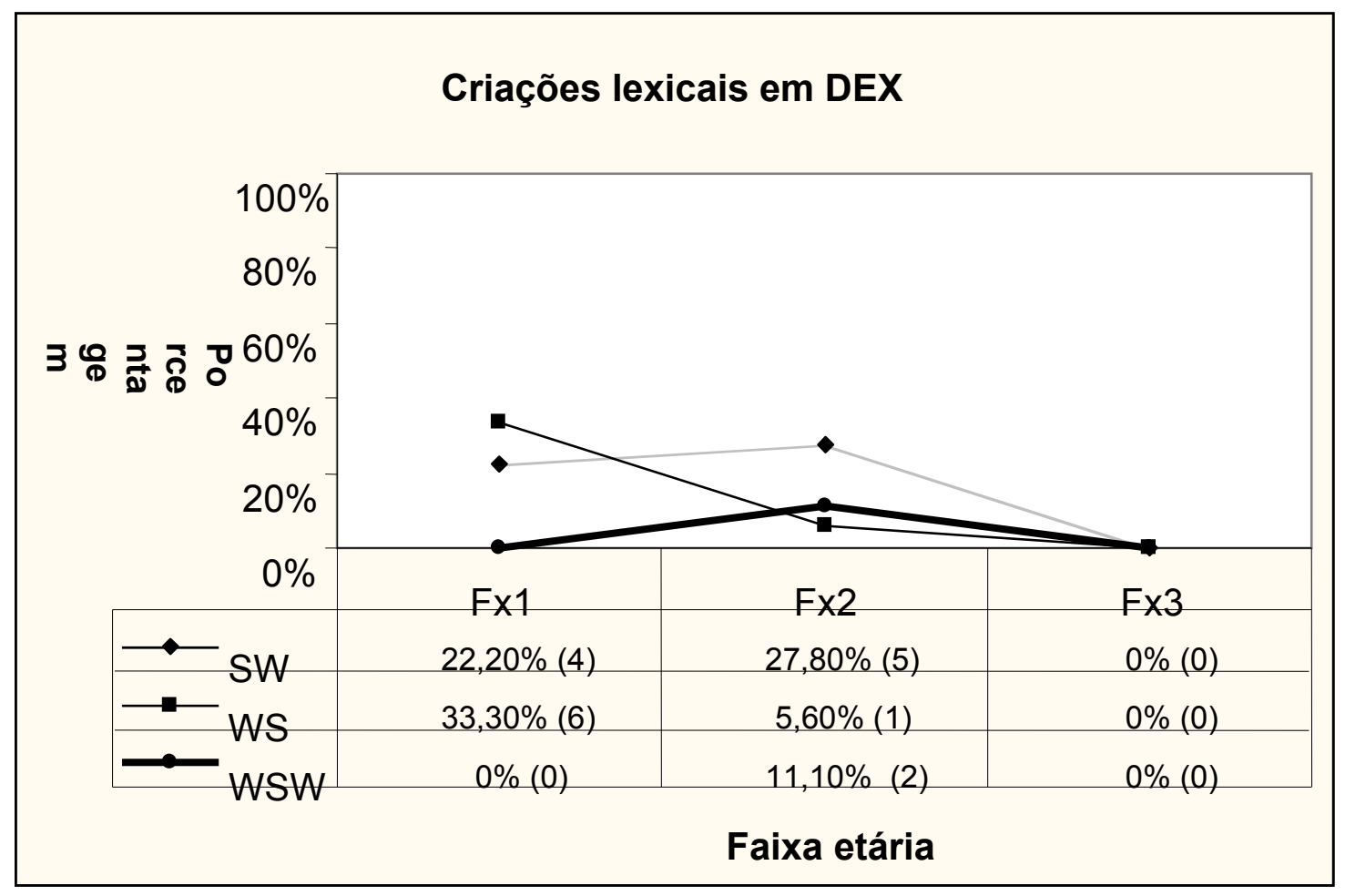

Gráfico 5: criações lexicais em DEX

Como o gráfico 5 ilustra, as criações lexicais ocorreram em Fx1 e Fx2. Em Fx1, houve a predominância do modelo WS, enquanto que em Fx2 de SW, e a partir de Fx3 esse tipo de processo parece não mais ocorrer.

A seguir, exemplos de criação lexical SW:
(31) ['bo.t $\mathrm{I}]$
'copo'
(G.A/ $1 ; 8)$
(32) ['pa.pI]
'lápis'
$(\mathrm{K} . \mathrm{W} / 2 ; 0)$

Exemplos de criação lexical WS:
(33) [bi.'bi]
'copo'
(P. C/ 1;5)
(34) [di.'ko]
'bola'
(J.V/ 2;1) 
Exemplo de criação lexical trissilábica WSW:

(35) [pa.'pa.ke] 'fósforo' (T.S/ 2;1)

Nota-se que houve em Fx1 predominância de léxico particular iâmbico (criações lexicais), entretanto, os dados são muito poucos para influenciarem na tendência geral presente no conjunto dos dados experimentais, a saber, a trocaica, que vai ao encontro dos achados de Rapp (1994).

\subsubsection{Resultado total}

A tabela 2 da seção 4.2 leva em consideração 1520 dados, desconsiderando os dados de erros de acento e léxico particular. A tabela 5 apresenta os valores descritivos no seu total, isto é, os 1565 dados presentes em DEX (sem subdivisões de acordo com o apagamento e sem descartar os dados de léxico particular e erros de acento), e é apresentada a média quando dados de léxico particular e erros não são considerados na contagem. T. significa 'todos os dados' e SLP significa 'sem o léxico particular' (os dados de erros de acento estão incluídos nessa categoria). 


\begin{tabular}{|c|c|c|c|c|c|c|c|c|c|c|}
\hline \multirow[t]{2}{*}{ Produção } & \multicolumn{2}{|c|}{ Média } & \multicolumn{2}{|c|}{$\begin{array}{l}\text { Desvio } \\
\text { Padrão }\end{array}$} & \multicolumn{2}{|c|}{ Mínimo } & \multicolumn{2}{|c|}{ Mediana } & \multicolumn{2}{|c|}{ Máximo } \\
\hline & T. & SLP & T. & SLP & T. & SLP & T. & SLP & T. & SLP \\
\hline M & 5,62 & 5,62 & 7,62 & 7,62 & 0,00 & 0,00 & 3,00 & 3,00 & 30,00 & 30,00 \\
\hline SW & 13,38 & 13,16 & 3,80 & 3,55 & 3,00 & 3,00 & 13,00 & 13,00 & 21,00 & 20,00 \\
\hline WS & 9,92 & 9,19 & 2,75 & 2,93 & 2,00 & 2,00 & 10,00 & 10,00 & 14,00 & 14,00 \\
\hline SWW & 2,00 & 1,95 & 1,65 & 1,65 & 0,00 & 0,00 & 2,00 & 2,00 & 5,00 & 5,00 \\
\hline WSW & 3,92 & 3,81 & 2,33 & 2,38 & 0,00 & 0,00 & 5,00 & 5,00 & 7,00 & 7,00 \\
\hline WWS & 2,88 & 2,85 & 2,41 & 2,38 & 0,00 & 0,00 & 3,00 & 3,00 & 7,00 & 7,00 \\
\hline
\end{tabular}

Tabela 5: Resultados descritivos gerais de DEX

Como a tabela mostra, o modelo SW é predominante no total de dados $(\mathrm{T} . \overline{\mathrm{x}}=13,38$ / SLP $\bar{x}=13,16)$ e é seguido pelo modelo WS (T. $\bar{x}=9,92 /$ SLP $\bar{x}=9,19)$. O trissílabo mais produzido foi o WSW $(\overline{\mathrm{x}}=3,92)$. Porém, após o teste de qui-quadrado de aderência, constatou-se que as médias de SW e WS, apesar de SW ter prevalecido aparentemente, não são significativamente diferentes em nenhum dos dois casos (T. e SLP) (Valor-P > 0,05).

No entanto, ainda é preciso saber se com o acréscimo dos dados de erros de acento e léxico particular, SW continua a predominar nas três faixas separadamente. A tabela 6 traz os resultados da média de produção desses dois modelos ao longo das três faixas:

\begin{tabular}{|c|c|c|c|c|c|c|}
\hline \multirow{2}{*}{ Faixas } & \multicolumn{2}{|c|}{ SW } & \multicolumn{2}{c|}{ WS } & \multicolumn{2}{c|}{ Valor-P } \\
\cline { 2 - 7 } & T. & SLP & T. & SLP & T. & SLP \\
\hline Fx1 & 13,76 & 13,46 & 9,5 & 7,92 & $>0,05$ & $>0,05$ \\
\hline Fx2 & 14,15 & 13,76 & 9,92 & 8,76 & $>0,05$ & $>0,05$ \\
\hline Fx3 & 12,43 & 12,43 & 10,56 & 10,56 & $>0,05$ & $>0,05$ \\
\hline
\end{tabular}

Tabela 6: $S W$ e WS nas faixas etárias de DEX (total) - teste qui-quadrado

A tabela 6 mostra que SW predomina nas três faixas. Após o teste de qui-quadrado de aderência entre as médias de produção de cada modelo dissilábico, constatou-se que as 
médias de SW e WS, apesar de SW prevalecer aparentemente, não são significativamente diferentes em nenhuma das três faixas (Valor-P > 0,05). No entanto, quando são analisados os valores absolutos com o Teste- $\mathrm{F}^{26}$, os seguintes resultados são obtidos:

\begin{tabular}{|c|c|c|}
\hline \multirow{2}{*}{ Faixas } & \multicolumn{2}{|c|}{ Valor-P } \\
& \multicolumn{2}{|c|}{ Valores de SW e WS } \\
\cline { 2 - 3 } & T. & SLP \\
\hline Fx1 & $<\mathbf{0 , 0 5}=+\mathbf{S W}-\mathbf{W S}$ & $<\mathbf{0 , 0 5}=+\mathbf{S W}-\mathbf{W S}$ \\
\hline Fx2 & $>0,05=+\mathrm{SW}+\mathrm{WS}$ & $>0,05=+\mathrm{SW}+\mathrm{WS}$ \\
\hline Fx3 & $<\mathbf{0 , 0 5}=+\mathbf{S W}-\mathbf{W S}$ & $<\mathbf{0 , 0 5}=+\mathbf{S W}-\mathbf{W S}$ \\
\hline As três faixas juntas & $<\mathbf{0 , 0 5}=+\mathbf{S W}-\mathbf{W S}$ & $<\mathbf{0 , 0 5}=+\mathbf{S W}-\mathbf{W S}$ \\
\hline
\end{tabular}

Tabela 7: $S W$ e WS nas faixas etárias de DEX (total) - teste- $F$

Por meio do Teste-F, que considera os valores absolutos ao invés de médias, notouse que há uma predominância significante de SW nos dados totais (T. e SLP). Quando as faixas são analisadas separadamente, SW predomina significantemente em Fx1 e Fx3, o que permite afirmar que há uma tendência trocaica em DEX, no período inicial de aquisição.

O gráfico 6 apresenta a porcentagem da produção de cada modelo nas três faixas etárias:

\footnotetext{
${ }^{26} \mathrm{O}$ Teste-F é utilizado para determinar se duas amostras têm variâncias diferentes. Os argumentos devem ser números, matrizes ou referências que contenham números.

${ }^{27} \mathrm{Na}$ tabela, $+\mathrm{SW}+\mathrm{WS}$ indica que houve tantos troqueus quanto iambos e que nenhum dos dois modelos apresentou predominância estatisticamente atestada. Quando é colocado $+\mathrm{SW}-\mathrm{WS}$ quer dizer que houve predominância significativa de SW, por exemplo.
} 


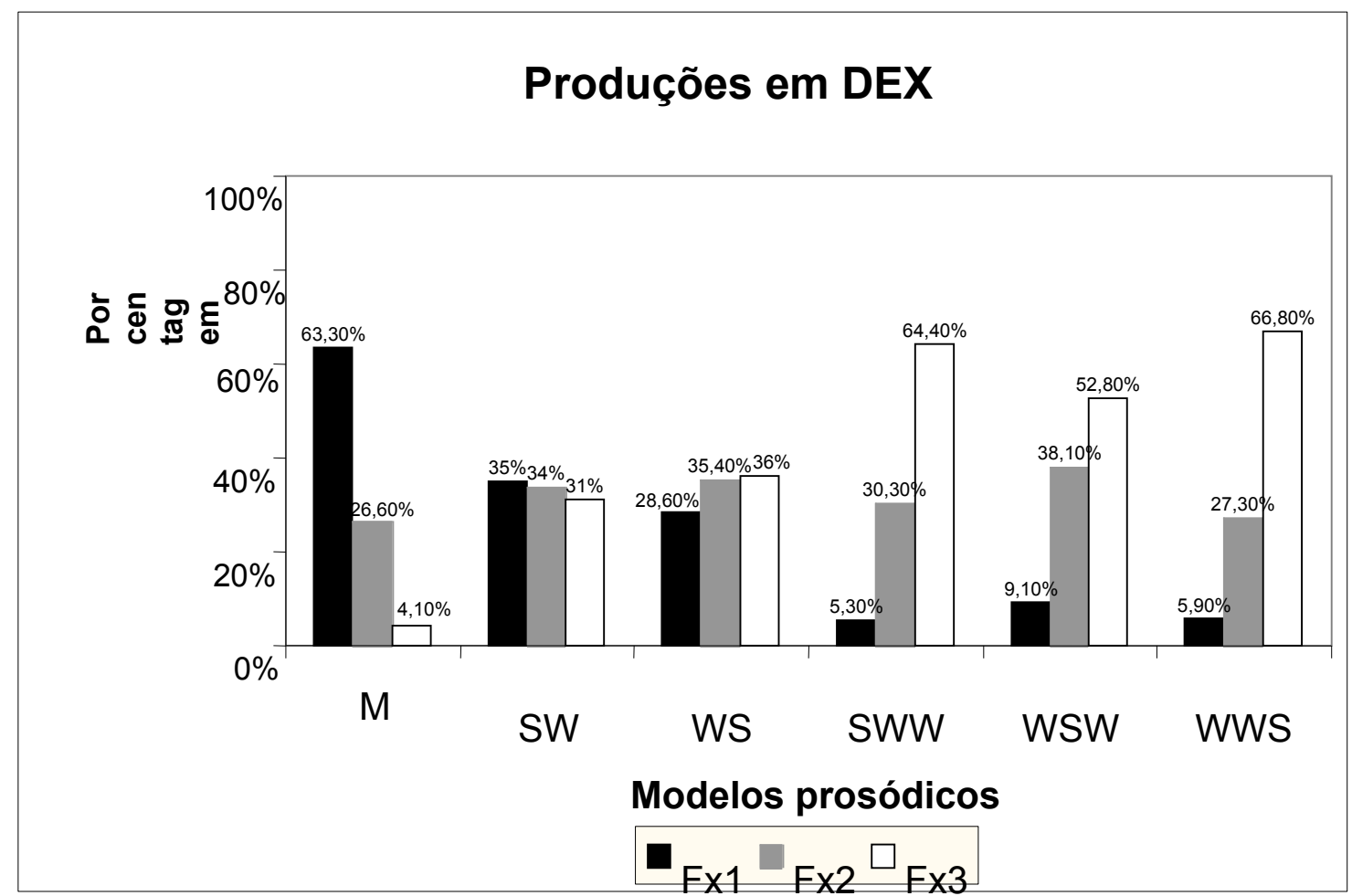

Gráfico 6: modelos prosódicos em DEX (total)

De acordo com o gráfico 6, as principais características de cada modelo foram: os monossílabos são mais freqüentes em Fx1, enquanto que SW é produzido com freqüência similar nas três faixas e a produção de WS aumenta a partir de Fx2. Os trissílabos passam a ser produzidos gradativamente e o seu maior número de ocorrências está em Fx3.

\subsection{Resumo}

Os resultados de DEX, no geral, apontam uma maior produção de dissílabos e uma tendência trocaica, que é significativa em Fx1e Fx3 nos dados sem léxico particular (SLP) e totais (T). Portanto, pode-se afirmar que os resultados de DEX corroboram o que é afirmado por Rapp (1994). 
Os modelos WSW e SWW, quando sofreram apagamento, foram produzidos, majoritariamente, como SW, enquanto que WWS como WS. Apesar de ter ocorrido em um número muito pequeno, que não tem significância estatística, os dados com deslocamento de acento e léxico particular foram predominantemente iâmbicos. Dessa maneira, a falta de um número maior de léxico particular pode estar contribuindo para a tendência encontrada em DEX, e a pergunta é: pode-se assumir uma tendência analisando dados que não representam todas as possibilidades de produção da criança, i.e. assumir a tendência trocaica com base nos dados de léxico comum que sofreram apagamento ou foram produzidos corretamente? O que se precisa ter em mente é que ao assumir a tendência trocaica com base no que foi apresentado de DEX, é deixada de lado a prosódia presente em dados de produções familiares e criações lexicais, que tendem a ser iâmbicas (cf. SANTOS, 2006; 2007; BAIA, 2006); além de desconsiderar dados de outra classe de palavra, a saber, os verbos, que estiveram ausentes no experimento desta pesquisa e no de Rapp (1994), mas que são contemplados na análise dos estudos observacionais. Após o teste-F (cf. tabela 7), constatou-se que SW prevalece nos dados totais, e, particularmente, em Fx1 e Fx3.

Cabe ressaltar que, curiosamente, enquanto houve uma tendência iâmbica nos dados com erros de acento e léxico particular, WS foi o modelo que mais sofreu apagamento em Fx1 favorecendo a produção de monossílabos (cf. tabela 2). O contexto não influenciou, pois todas as palavras foram produzidas isoladamente. O que pode ser verificado em estudos posteriores é se a duração desses monossílabos equivale à duração de um dissílabo. 


\section{DADOS NATURALÍSTICOS (DES)}

Para haver uma comparação entre os resultados, a análise de DES é realizada tal como foi a de DEX, isto é, são considerados os mesmos modelos prosódicos e faixas etárias de DEX na análise. No entanto, diferentemente do estudo experimental desta pesquisa e do de Rapp (1994), e assim como nos demais estudos observacionais (BONILHA, 2004; BAIA, 2006; SANTOS, 2006, 2007), estão presentes dados de verbos em DES.

No intuito de se verificar se o tipo de léxico e classe de palavra influenciam na tendência prosódica de DES, os resultados são divididos em uma seção que lida apenas com dados de nomes, outra só com verbos, e, por último, uma seção de resultados que contemplam as duas classes de palavras juntas.

\subsection{Metodologia}

Os dados naturalísticos analisados são de uma criança do sexo feminino (LUI), entre 1;5 a 3;0 anos, e pertencem ao projeto desenvolvido na USP: A aquisição do ritmo em Português Brasileiro - Processos de Ancoragem (SANTOS, 2005). Assim como no estudo experimental, trata-se de produções de palavras transcritas auditivamente com o uso do alfabeto fonético internacional (IPA). Os dados foram transcritos pela autora deste trabalho e, como nos dados experimentais, contou com a ajuda de outro fonólogo. Na comparação das transcrições, houve $95 \%$ de concordância, o que indica que os dados foram corretamente transcritos pela autora deste trabalho. A respeito dos 5\% discordantes, após discussão, chegou-se a um acordo sobre a produção. Ao todo foram obtidos 1177 dados, sendo 761 nomes $(64,7 \%)$ e 416 verbos $(35,3 \%)$. 
Para haver comparação com DEX, as mesmas faixas etárias de DEX são seguidas na análise de DES: Fx1 $(1 ; 5-2 ; 0)$, Fx2 $(2 ; 1-2 ; 6)$, Fx3 $(2 ; 7-3 ; 0)$. Por terem sido coletados antes de DEX, não foram incluídos dados de imitação em DES, embora seja assumido nesta pesquisa que dados de imitação não fujam da gramática infantil, e, portanto, que tal diferença metodológica não afeta os resultados.

Para a coleta de dados, foram utilizadas duas sessões por mês, sendo que cada sessão tinha a duração de meia hora.

\subsection{Resultados}

$\mathrm{Na}$ análise de dados naturalísticos, para fazer um paralelo com DEX, os dados são analisados, em um primeiro momento, levando apenas em consideração os nomes, tal como DEX, e logo após os verbos são inseridos por terem sido considerados na análise dos demais estudos observacionais e também porque, segundo Santos (2007), as duas classes de palavra apresentam comportamento prosódico diferenciado. Além disso, o léxico presente em DES é analisado separadamente, desconsiderando os dados de léxico particular, os quais foram pouquíssimos e não apresentaram significância estatística em DEX. Dessa maneira, após a análise dos dados de léxico comum, são inseridos os dados de léxico particular no intuito de se verificar a existência ou não de evidências a favor do papel desse léxico na tendência iâmbica apontada pelos estudos observacionais (cf. SANTOS, 2001, 2007; BONILHA, 2004; BAIA, 2006). 


\subsubsection{Produções pelo tamanho da palavra}

Quanto ao tamanho da palavra, assim como ocorreu em DEX, os dissílabos predominam no total de dados, como é possível observar na tabela 1:

\begin{tabular}{|l|c|c|c|c|}
\hline & Monossílabos & Dissílabos & Trissílabos & Total \\
\hline Fx1 & $47(59,4 \%)$ & $\mathbf{2 5 7}(\mathbf{2 8 , 9 \%})$ & $15(7,2 \%)$ & 319 \\
\hline Fx2 & $17(21,5 \%)$ & $\mathbf{3 7 0}(\mathbf{4 1 , 5 \% )}$ & $105(50,8 \%)$ & 492 \\
\hline Fx3 & $15(19,1 \%)$ & $\mathbf{2 6 4}(\mathbf{2 9 , 6 \% )}$ & $87(42 \%)$ & 366 \\
\hline Total & $79(100 \%)$ & $\mathbf{8 9 1}(\mathbf{1 0 0} \%)$ & $207(100 \%)$ & $1177(100 \%)$ \\
\hline
\end{tabular}

Tabela 1: O tamanho da palavra em DES

\subsubsection{Resultados: DES-nomes}

Para que possa ser feita a comparação com DEX, nesta seção são analisados apenas dados de nomes. A tabela $2^{28}$ apresenta os resultados 638 dados $^{29}$ de DES-nomes. Os resultados são apresentados da mesma forma que em DEX.

\footnotetext{
${ }^{28}$ Como os dados são de apenas uma criança, $\mathrm{N}$ se modifica em DES:

$\overline{\mathbf{x}}=\sum \mathbf{x} \quad \overline{\mathbf{x}}=$ média $/ \sum=$ soma $/ \mathrm{x}=$ total de produções de determinado modelo prosódico/ $\mathbf{N}$ : total $\mathbf{N}$ de meses observados em seqüência (20 meses - 1;5 - 3;0).

${ }^{29} \mathrm{O}$ total de dados de nomes é de 761 , porém deixaram de ser considerados nesta contagem inicial os dados de erros de acento (2) e léxico particular - produção familiar (86) e criação lexical (35) - que são analisados separadamente.
} 


\begin{tabular}{|c|c|c|c|c|c|c|}
\hline Alvo & Produção & Média & Desvio Padrão & Mínimo & Mediana & Máximo \\
\hline \multirow[t]{2}{*}{ SW } & $\mathbf{M}$ & 5,15 & 2,94 & 1,00 & 5,00 & 12,00 \\
\hline & $\mathbf{S W}$ & 15,50 & 6,18 & 3,00 & 16,00 & 25,00 \\
\hline \multirow[t]{2}{*}{ WS } & $\mathbf{M}$ & 0,55 & 0,82 & 0,00 & 0,00 & 2,00 \\
\hline & $\mathbf{W S}$ & 7,00 & 3,47 & 2,00 & 7,00 & 14,00 \\
\hline \multirow[t]{3}{*}{ SWW } & $\mathbf{M}$ & 0,05 & 0,22 & 0,00 & 0,00 & 1,00 \\
\hline & SW & 0,10 & 0,30 & 0,00 & 0,00 & 1,00 \\
\hline & SWW & 0,10 & 0,30 & 0,00 & 0,00 & 1,00 \\
\hline \multirow[t]{4}{*}{ WSW } & M & 0,25 & 0,55 & 0,00 & 0,00 & 2,00 \\
\hline & SW & 0,50 & 0,60 & 0,00 & 0,00 & 2,00 \\
\hline & WS & 1,50 & 3,10 & 0,00 & 0,00 & 13,00 \\
\hline & WSW & 6,60 & 5,11 & 0,00 & 6,50 & 17,00 \\
\hline \multirow[t]{3}{*}{ WWS } & M & 0,00 & 0,00 & 0,00 & 0,00 & 0,00 \\
\hline & WS & 0,15 & 0,36 & 0,00 & 0,00 & 1,00 \\
\hline & WWS & 0,60 & 0,82 & 0,00 & 0,00 & 2,00 \\
\hline
\end{tabular}

Tabela 2: Resultados descritivos DES-nomes

Os dados da tabela 2 serão retomados e discutidos ao longo da análise dos dados. Como é possível observar, nos dados totais, a maior média de produção ocorreu na produção de SW quando o alvo era $\mathrm{SW}(\overline{\mathrm{x}}=15,50)$, o que aponta uma tendência de produção de troqueus. Essa tendência foi seguida pela produção de WS quando o alvo era WS $(\bar{x}=7,00)$.

\subsubsection{Produções monossilábicas}

Na análise de produções monossilábicas após apagamento em alvo SW, WS, SWW, WSW, WWS, foram encontradas 120 produções monossilábicas (18,8\% dos dados). A sílaba tônica (S) permaneceu em 84,1\% (101) dos casos, enquanto em apenas 15,9\% (19) dos casos a sílaba átona (W) foi a que permaneceu: 


$\begin{array}{lll}\text { (01) [nĩ ] } & \text { 'menino' } & 1 ; 5 \\ \text { (02) [li] } & \text { 'livro' } & 1 ; 5 \\ \text { (03) [mãw̃ ] } & \text { 'irmão' } & 1 ; 8\end{array}$

W

$\begin{array}{lll}(04)[\mathrm{ta}] & \text { 'porta' } & 1 ; 7 \\ (05)[\mathrm{ko}] & \text { 'coração' } & 1,8\end{array}$

Como foi apresentado na tabela 2 da seção 5.2.2, o modelo prosódico alvo que sofreu mais apagamento e foi produzido como monossílabo, considerando os dados na sua totalidade, foi o SW ( $\bar{x}=5,15)$. O gráfico 1 mostra qual o modelo prosódico foi mais alvo de apagamento em cada faixa etária aqui considerada: 


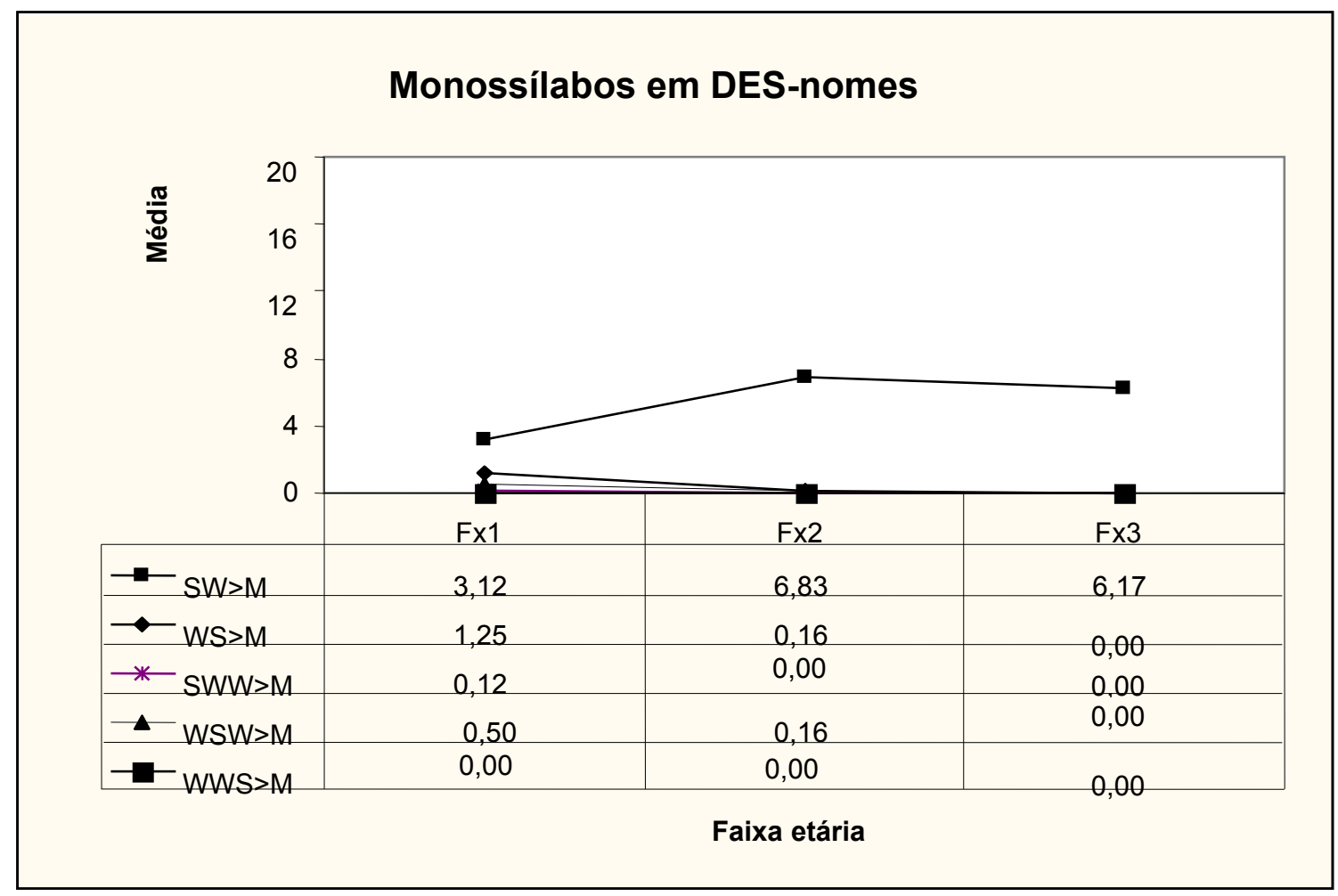

Gráfico 1: Monossílabos em DES-nomes

Observa-se que o processo de apagamento que favorece a produção monossilábica ao longo das faixas ocorreu principalmente em SW.

\subsubsection{Produções dissilábicas}

Como foi apresentado na tabela 2, considerando os dados na sua totalidade (desconsiderando dados de erro de acento e léxico particular), o modelo SW foi o mais produzido de acordo com a sua forma alvo $(\mathrm{SW}>\mathrm{SW} \overline{\mathrm{x}}=15,50)$. O modelo WS, embora não tenha sido o alvo principal de apagamento que favoreceu os monossílabos, teve um número menor de produções tendo ele como alvo $(\overline{\mathrm{x}}=7,00)$. Porém, após o teste de qui-quadrado de 
aderência, constatou-se que as médias de SW e WS, apesar de SW ter prevalecido aparentemente, não são significativamente diferentes (Valor-P > 0,05).

No que se refere aos trissílabos, quando SWW sofreu apagamento que resultasse em dissílabo, o modelo SW foi o que foi produzido $(\overline{\mathrm{x}}=0,10)$. O modelo WSW sofreu mais apagamento que resultasse WS $(\overline{\mathrm{x}}=1,50)$ do que $\mathrm{SW}(\overline{\mathrm{x}}=0,50)$ - a diferença entre as médias não é significativa estatisticamente - , assim como o modelo WWS sofreu apagamento que favoreceu WS $(\overline{\mathrm{x}}=0,15)$.

O gráfico 2 apresenta o total de produção de dissílabos (devido à forma alvo ou após apagamento em trissílabos) em cada faixa:

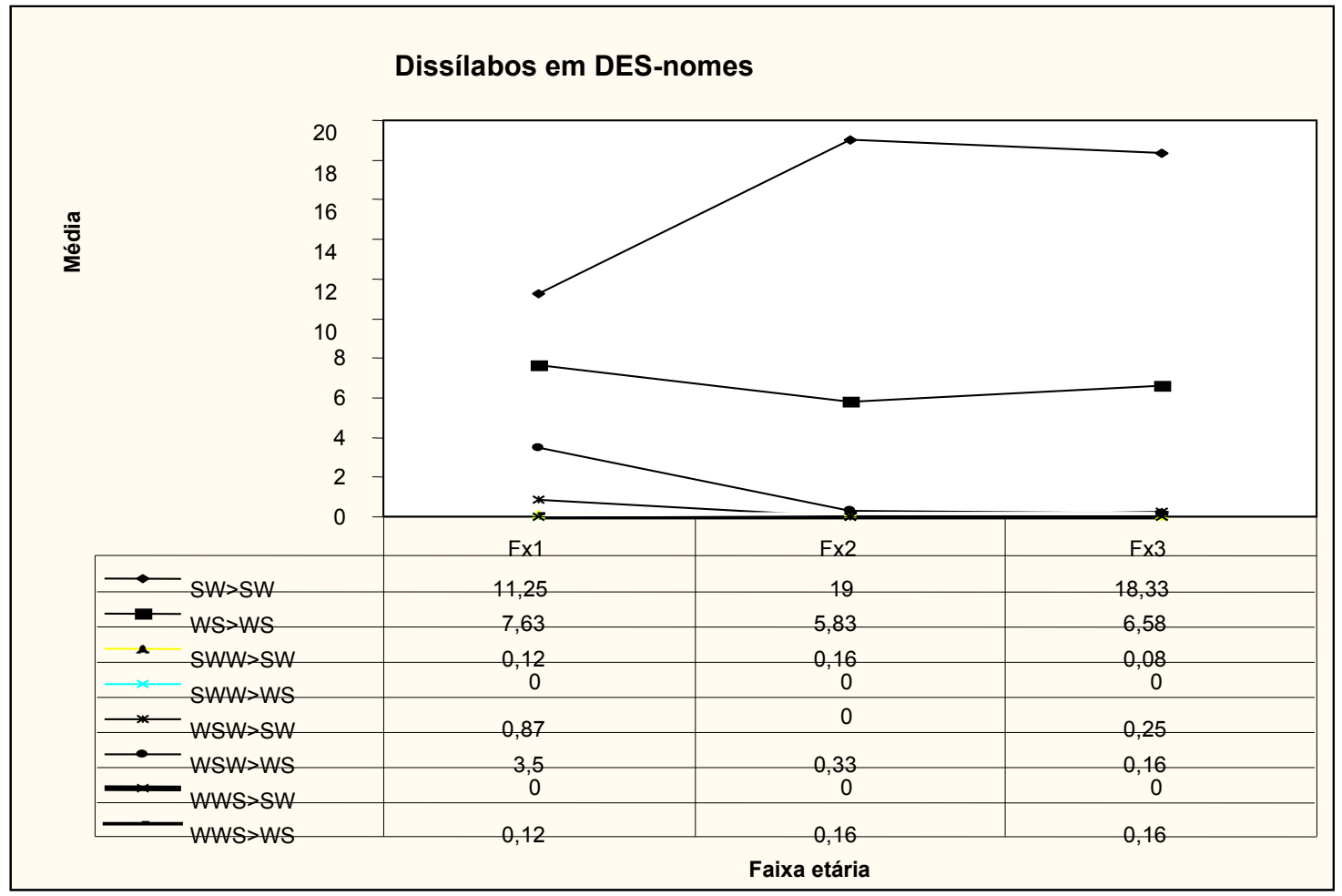

Gráfico 2: Dissílabos em DES-nomes 
Observa-se que o dissílabo mais produzido nas três faixas etárias é o SW quando o alvo é SW. Quanto ao modelo WS, quando produzido de acordo com o alvo WS, o seu número de produções é inferior ao de SW nas três faixas. O modelo WS predominou em Fx1 quando o alvo era WSW e em todas as faixas quando o alvo era WWS. Não houve caso de SWW $>$ WS ou WWS $>$ SW. Em seguida, são apresentados exemplos dessas produções dissilábicas:

$\mathbf{S W}>\mathbf{S W}$

$\begin{array}{lll}\text { (06) ['ka.u] } & \text { 'carro' } & 1 ; 7 \\ \text { (07) ['pa.tu] } & \text { 'pato' } & 1 ; 8\end{array}$

$\mathbf{W S}>\mathbf{W S}$

(08) [Sa.'pew] 'chapéu' 1;11

(09) [bo.'ne] 'boné' 1;11

SWW $>$ SW

(10) ['mõ.ke] 'Mônica' 1;5

(11) ['mu.zI] 'música' 2;5

$\mathbf{W S W}>\mathbf{S W}$

(12) ['e.U] 'coelho' $1 ; 5$

(13) ['pa.tu] 'sapato' $1 ; 9$ 
WSW $>$ WS
(14) [bu.'ni]
'bonito' $\quad 1 ; 5$
(15) [pa.'tu]
'sapato' $1 ; 8$

\section{WWS > WS}

$\begin{array}{lll}\text { (16) [vi.'ãw] } & \text { 'avião’ } & 2 ; 0 \\ \text { (17) [a.'sãw ] } & \text { 'coração' } & 2 ; 2\end{array}$

As médias de $\mathrm{SW}>\mathrm{SW}(\mathrm{Fx} 1 \overline{\mathrm{x}}=11,25, \mathrm{Fx} 2 \overline{\mathrm{x}}=19, \mathrm{Fx} 3 \overline{\mathrm{x}}=18,33)$ foram comparadas às médias de WS>WS $(\mathrm{Fx} 1 \overline{\mathrm{x}}=7,62, \mathrm{Fx} 2: 5,83, \mathrm{Fx} 3 \overline{\mathrm{x}}=6,58)$, e após o teste de quiquadrado de aderência entre as médias de produção de cada modelo dissilábico, comparando médias por cada faixa etária, constatou-se que as médias de SW e WS, apesar de SW ter prevalecido aparentemente, não são significativamente diferentes em Fx1 (Valor$\mathrm{P}>0,05)$, mas são em Fx2/Fx3 (Valor-P $<0,05$ ), o que indica que SW é significativamente predominante nessas faixas.

\subsubsection{Produções trissilábicas}

Nos dados espontâneos de 1;5 a 3;0 anos, notou-se que os trissílabos não são muito freqüentes e que, em geral, como está na tabela 2, o modelo mais produzido foi o WSW $(\bar{x}=6,60)$, seguido por WWS $(\bar{x}=0,60)$ e SWW $(\bar{x}=0,10)$. O gráfico 3 mostra o total de produção de trissílabos ao longo das faixas etárias: 


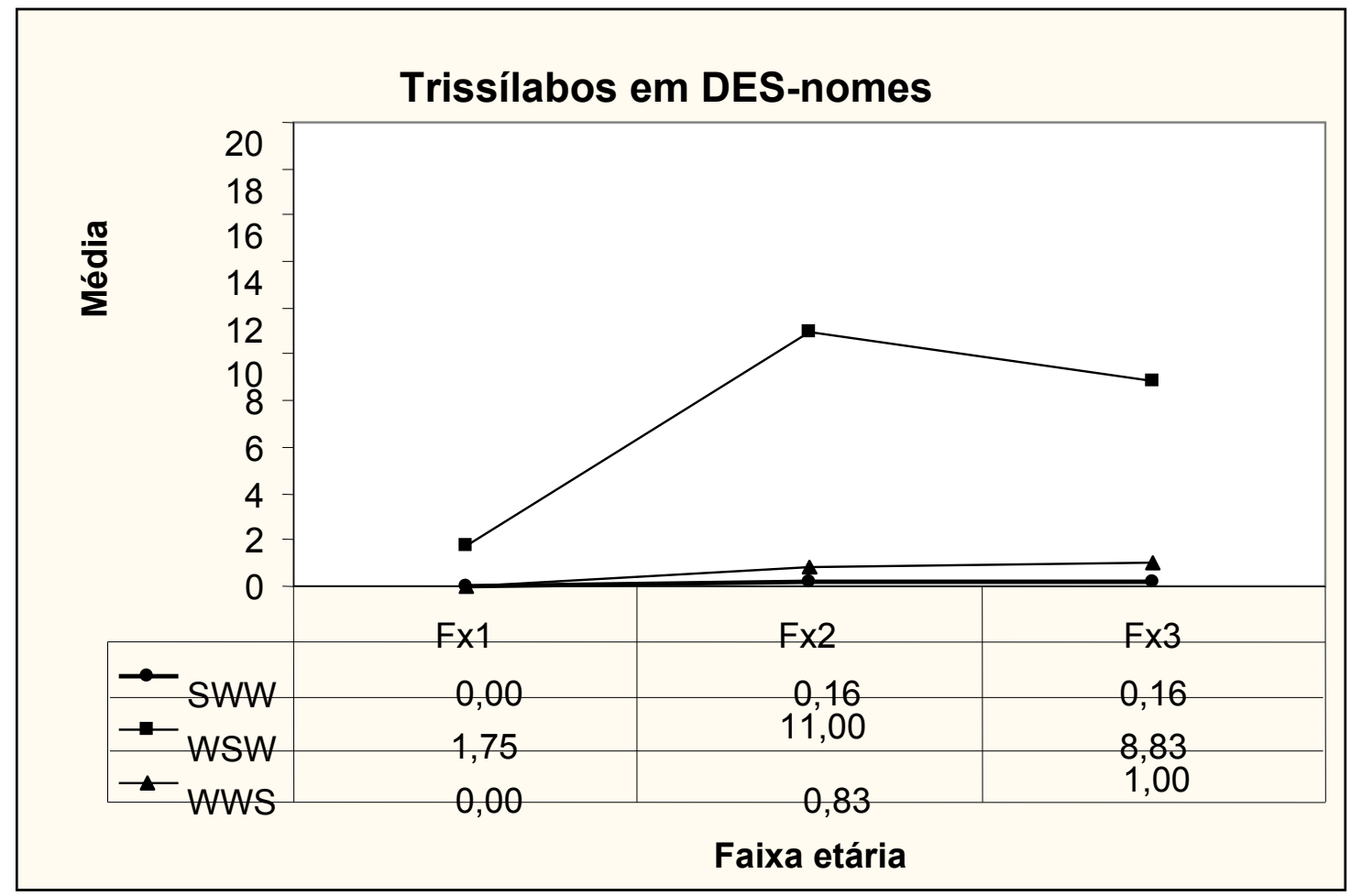

Gráfico 3: Trissílabos em DES-nomes

Como o gráfico 3 mostra, a produção trissilábica aumenta a partir de Fx2, e o trissílabo mais produzido nas três faixas é o WSW.

A seguir são apresentados exemplos de produções trissilábicas:

SWW $>$ SWW

(18) ['ma.zi.ku] 'mágico' 2;1

(19) ['mu.zi.ke] 'música' 2;10

WSW $>$ WSW

(19) [ka.'va.lu] 'cavalo' $1 ; 9$

(20) [is.'te.le] 'estrela' 2;1 


\section{WWS $>$ WWS}
(21) [ko.ra.’sãw] 'coração' 2;2
(22) [ma.ka.'xãw ] 'macarrão' 2;9

\subsubsection{Deslocamento de acento}

Houve apenas 2 casos $(0,26 \%$ do total de dados $)$ de deslocamento de acento em DES-nomes, que favoreceram o modelo WS em Fx1:

$\begin{array}{lll}\text { (23) [pi.'pa] } & \text { 'pipa' } & 1 ; 8 \\ \text { (24) [a.'wa] } & \text { 'água' } & 1 ; 9\end{array}$

\subsubsection{Léxico Particular}

Em DES-nomes foi possível encontrar dados dos dois tipos de léxico particular, a saber, produções familiares e criações lexicais.

\section{Criações Lexicais}

Em DES-nomes, houve 35 casos de criações lexicais (4,5\% do total de dados); quantidade bem pequena, assim como a quantidade de dados de erro de acento. Como o gráfico 4 apresenta, a maior parte das produções foi composta por dissílabos e houve apenas criação lexical trissilábica dos modelos WSW e WWS: 


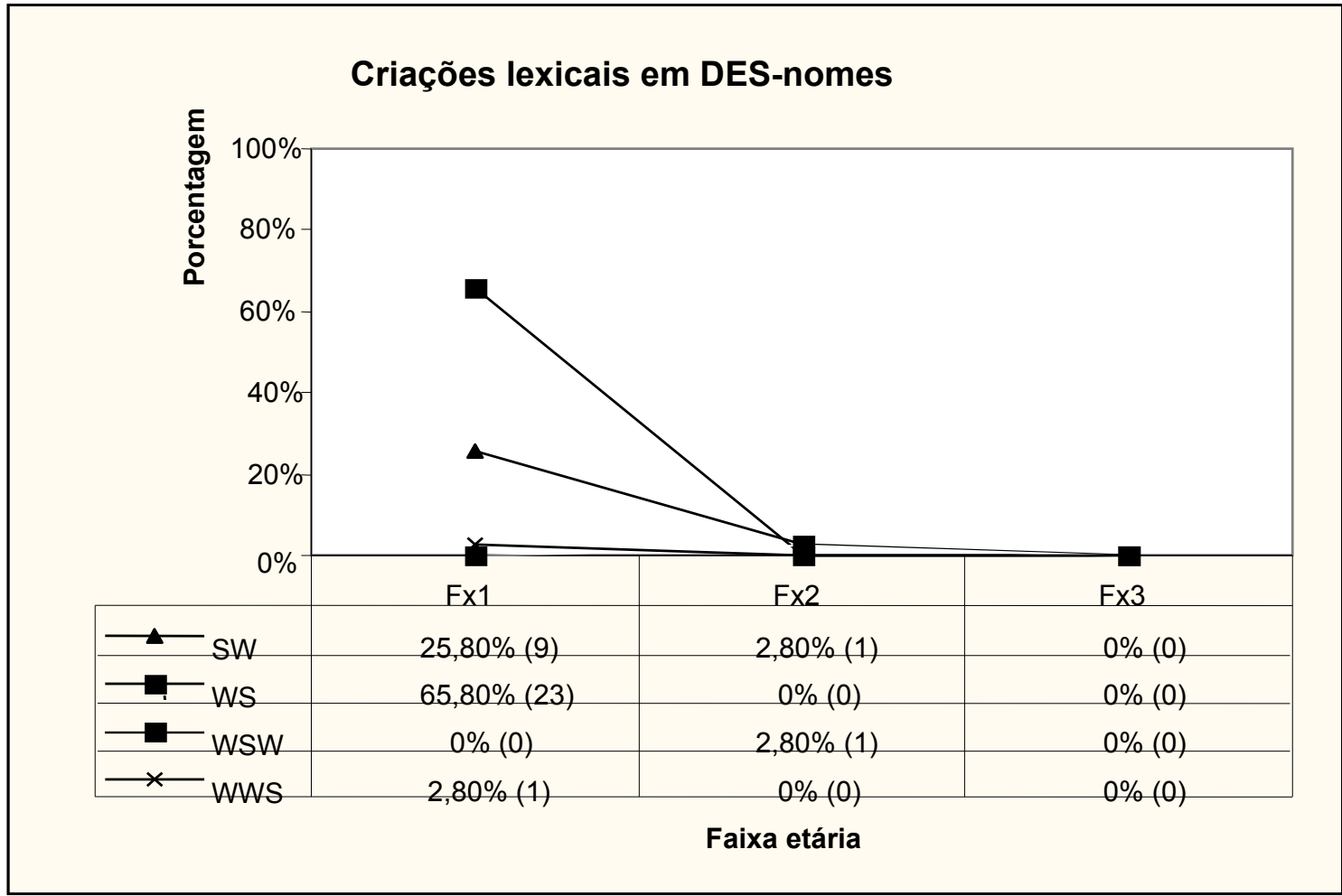

áfico 4: criações lexicais em DES-nomes

Como o gráfico 4 apresenta, as criações lexicais ocorreram em Fx1 e o modelo prosódico que sobressaiu, majoritariamente, foi o WS. Alguns exemplos de criações lexicais:

SW
(25) $[$ 'pe.t5 I]
'pássaro'
$1 ; 5$
(26) ['u.fi]
'urso'
$1 ; 5$

WS

$\begin{array}{lll}\text { (27) [pe.'ni] } & \text { 'coelho' } & 1,5 \\ \text { (28) [bu.'bu] } & \text { 'livro' } & 1 ; 6\end{array}$


WSW

(29) [si.'te.le] 'pijama' 2;1

WWS

(30) [ve.ku.'a] 'vaca' $1 ; 8$

As criações tendem a ser iâmbicas em DES-nomes, no entanto, como foi dito no início desta seção, o número é muito pequeno em relação ao total de dados $(4,5 \%)$ para poder influenciar na tendência prosódica geral desse conjunto de dados.

Produções familiares

Em DES-nomes, houve 86 casos de produções familiares $(11,3 \%$ do total de dados); quantidade, assim como a quantidade de dados de erro de acento, pequena em relação ao conjunto total de dados. Como o gráfico 5 apresenta, houve apenas produções de dissílabos: 


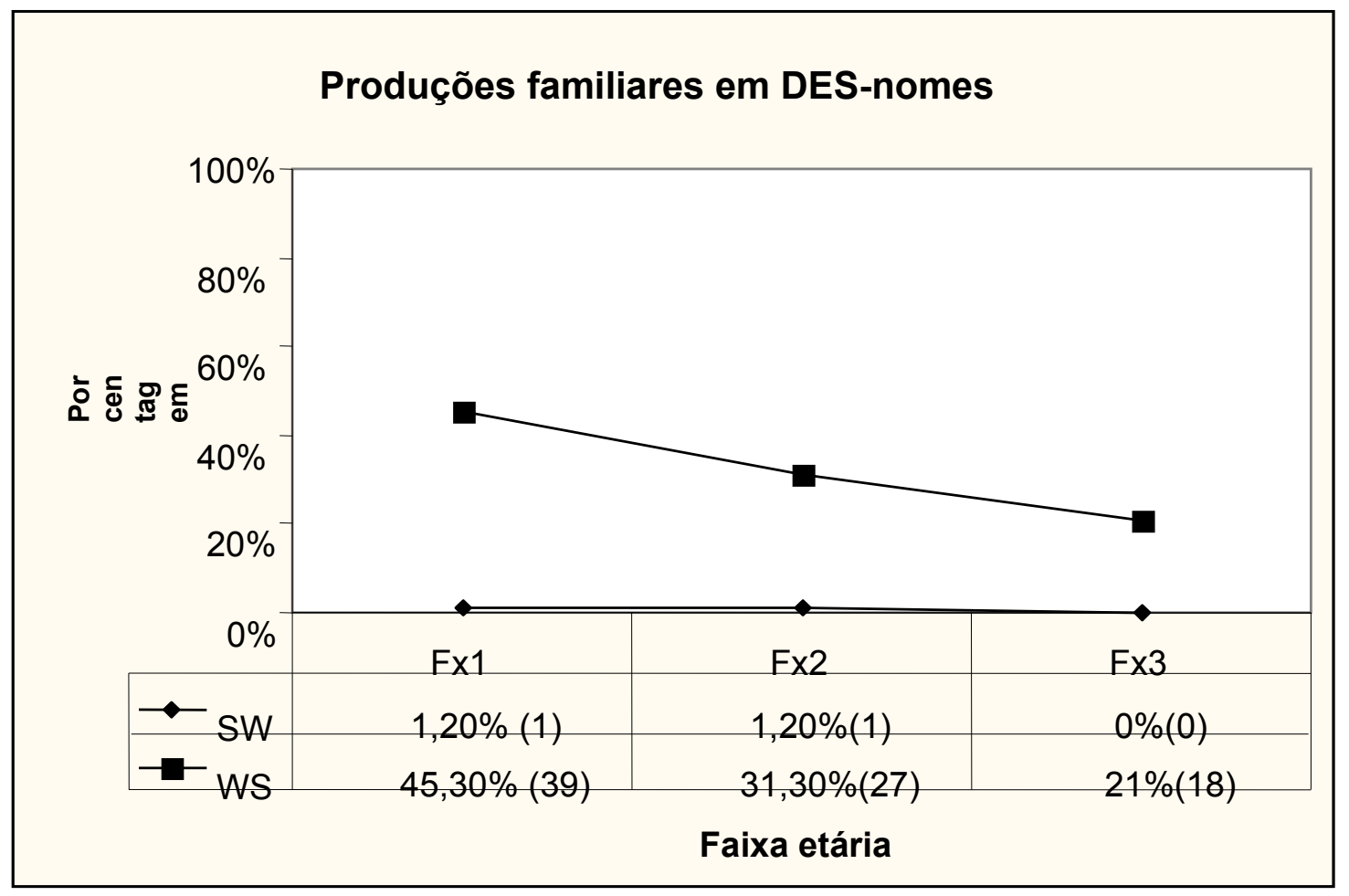

Gráfico 5: Produções familiares em DES-nomes

As produções familiares são majoritariamente iâmbicas e estão presente em maior número em Fx1. O número de produções decresce gradativamente até Fx3, porém a tendência de produção de iambos permanece ao longo das três faixas. Exemplos de produções familiares:

\section{SW}
(31) ['ka.ke]
'sujeira' $\quad 1 ; 5$
(32) ['pe.te]
'chupeta' $1 ; 8$ 
WS
(33) [pa.'pa]
'comida' $1 ; 5$
(34) [do.'doj]
'machucado' 2;0

Assim como as criações lexicais, as produções familiares tendem a ser iâmbicas em DES-nomes, no entanto, como foi citado no início desta seção, o número é pequeno em relação ao total de dados (11,3\% do total). O próximo passo é, então, verificar o papel desse tipo de léxico na tendência prosódica geral dos dados, observar se a presença dele afeta ou não os resultados de DES-nomes apresentados até o momento.

\subsubsection{Resultado total: DES-nomes}

A tabela 2 da seção 5.2.2 leva em consideração 638 dados de um lado, desconsiderando os dados de erros de acento e léxico particular. A tabela 3 apresenta de um lado os valores descritivos no seu total, isto é, para se obter tais resultados foram considerados os 761 dados de nomes em DES (sem subdivisões de acordo com o apagamento e sem descartar os dados de léxico particular e erros de acento), e é apresentada a média quando dados de léxico particular e erros não são considerados na contagem. T. significa todos os dados e SLP significa sem o léxico particular (mais os erros de acento). 


\begin{tabular}{|c|c|c|c|c|c|c|c|c|c|c|}
\hline \multirow{2}{*}{ Produção } & \multicolumn{2}{|c|}{ Média } & \multicolumn{2}{c|}{$\begin{array}{c}\text { Desvio } \\
\text { Padrão }\end{array}$} & \multicolumn{2}{c|}{ Mínimo } & \multicolumn{2}{c|}{ Mediana } & \multicolumn{2}{c|}{ Máximo } \\
\cline { 2 - 11 } & T. & SLP & T. & SLP & T. & SLP & T. & SLP & T. & SLP \\
\hline M & 6,00 & 6,00 & 2,82 & 2,82 & 1,00 & 1,00 & 6,00 & 6,00 & 12,00 & 12,00 \\
\hline SW & 16,70 & 16,15 & 6,40 & 6,52 & 3,00 & 3,00 & 17,00 & 16,00 & 27,00 & 27,00 \\
\hline WS & 14,05 & 9,55 & 11,09 & 6,16 & 2,00 & 2,00 & 10,50 & 7,50 & 42,00 & 29,00 \\
\hline SWW & 0,10 & 0,10 & 0,30 & 0,30 & 0,00 & 0,00 & 0,00 & 0,00 & 1,00 & 0,00 \\
\hline WSW & 6,65 & 6,55 & 5,09 & 5,09 & 0,00 & 0,00 & 6,50 & 6,50 & 17,00 & 17,00 \\
\hline WWS & 0,55 & 0,55 & 0,88 & 0,88 & 0,00 & 0,00 & 0,00 & 0,00 & 3,00 & 3,00 \\
\hline
\end{tabular}

Tabela 3: Resultados descritivos gerais de DES-nomes (totais e sem léxico particular)

Como a tabela mostra, o modelo SW é predominante no total de dados com a presença $(\overline{\mathrm{x}}=16,70)$ ou ausência $(\overline{\mathrm{x}}=16,15)$ do léxico particular e é seguido pelo modelo WS, porém, após o teste de qui-quadrado, notou-se que a predominância de SW em nenhuma das situações foi significativa (Valor-P > 0.05). Além disso, o trissílabo mais produzido foi o WSW $(\overline{\mathrm{x}}=6,65)$.

No entanto, ainda se precisa saber se com o acréscimo dos dados de erros de acento e léxico particular, SW continua a predominar nas três faixas separadamente. A tabela 4 traz os resultados da média de produção dos dois modelos dissilábicos ao longo das três faixas com e sem o léxico particular: 


\begin{tabular}{|c|c|c|c|c|c|c|}
\hline \multirow{2}{*}{ Faixas } & \multicolumn{2}{|c|}{ SW } & \multicolumn{2}{c|}{ WS } & \multicolumn{2}{c|}{ Valor-P } \\
\cline { 2 - 7 } & T. & SLP & T. & SLP & T. & SLP \\
\hline Fx1 & 13,5 & 12,25 & 19,5 & 10,25 & $>0,05$ & $>0,05$ \\
\hline Fx2 & 19,5 & 19,33 & 13,6 & 12,16 & $>0,05$ & $>0,05$ \\
\hline Fx3 & $\mathbf{1 8 , 1}$ & $\mathbf{1 8 , 1 6}$ & $\mathbf{7 , 5}$ & $\mathbf{6 , 0 0}$ & $<\mathbf{0 , 0 5}$ & $<\mathbf{0 , 0 5}$ \\
\hline
\end{tabular}

Tabela 4: $S W$ e WS nas faixas etárias de DES-nomes (totais e sem o léxico particular)- teste qui-quadrado

A tabela 4 mostra que, apesar de SW ter predominado, aparentemente, nos dados em geral, quando os dados são divididos em três faixas etárias, encontra-se uma predominância de WS em Fx1 com os dados de léxico particular presentes, o que ocorre devido ao acréscimo desse léxico no conjunto de dados. Após o teste de qui-quadrado de aderência entre as médias de produção de cada modelo dissilábico, comparando médias por cada faixa etária, constatou-se que as médias de SW e WS não são significativamente diferentes em nenhuma das duas situações em Fx1 e Fx2 (Valor-P > 0,05), apenas em Fx3 (Valor-P $<0,05) \mathrm{SW}$ é significativamente predominante com ou sem o léxico particular presente. Para deixar mais claro qual modelo predomina e se é significativo, realizou-se o teste-F. Os resultados são:

\begin{tabular}{|c|c|c|}
\hline \multirow{2}{*}{ Faixas } & \multicolumn{2}{|c|}{ Valor-P } \\
& \multicolumn{2}{|c|}{ Valores de SW e WS } \\
\cline { 2 - 3 } & T. & SLP \\
\hline Fx1 & $>0,05=+\mathrm{SW}+\mathrm{WS}$ & $>0,05=+\mathrm{SW}+\mathrm{WS}$ \\
\hline $\mathrm{Fx} 2$ & $>0,05=+\mathrm{SW}+\mathrm{WS}$ & $>0,05=+\mathrm{SW}+\mathrm{WS}$ \\
\hline Fx3 & $<\mathbf{0 , 0 5}=+\mathrm{SW}-\mathrm{WS}$ & $>\mathbf{0 , 0 5}=+\mathbf{S W}-\mathrm{WS}$ \\
\hline As três faixas juntas & $<0,05=+\mathrm{SW}+\mathrm{WS}$ & $>0,05=+\mathrm{SW}+\mathrm{WS}$ \\
\hline
\end{tabular}

Tabela 5: SW e WS nas faixas etárias de DES- nomes (total) - teste- $F$

Por meio do Teste-F, que considera os valores absolutos ao invés de médias, notouse que não há um modelo predominante significativamente nos dados totais e nem em Fx1 
e Fx2 quando as faixas são analisadas separadamente. Em Fx3, como foi observado com o teste qui-quadrado, há predominância significativa de SW.

O gráfico 6 apresenta a porcentagem da produção de cada modelo nas três faixas etárias com todos os dados presentes:

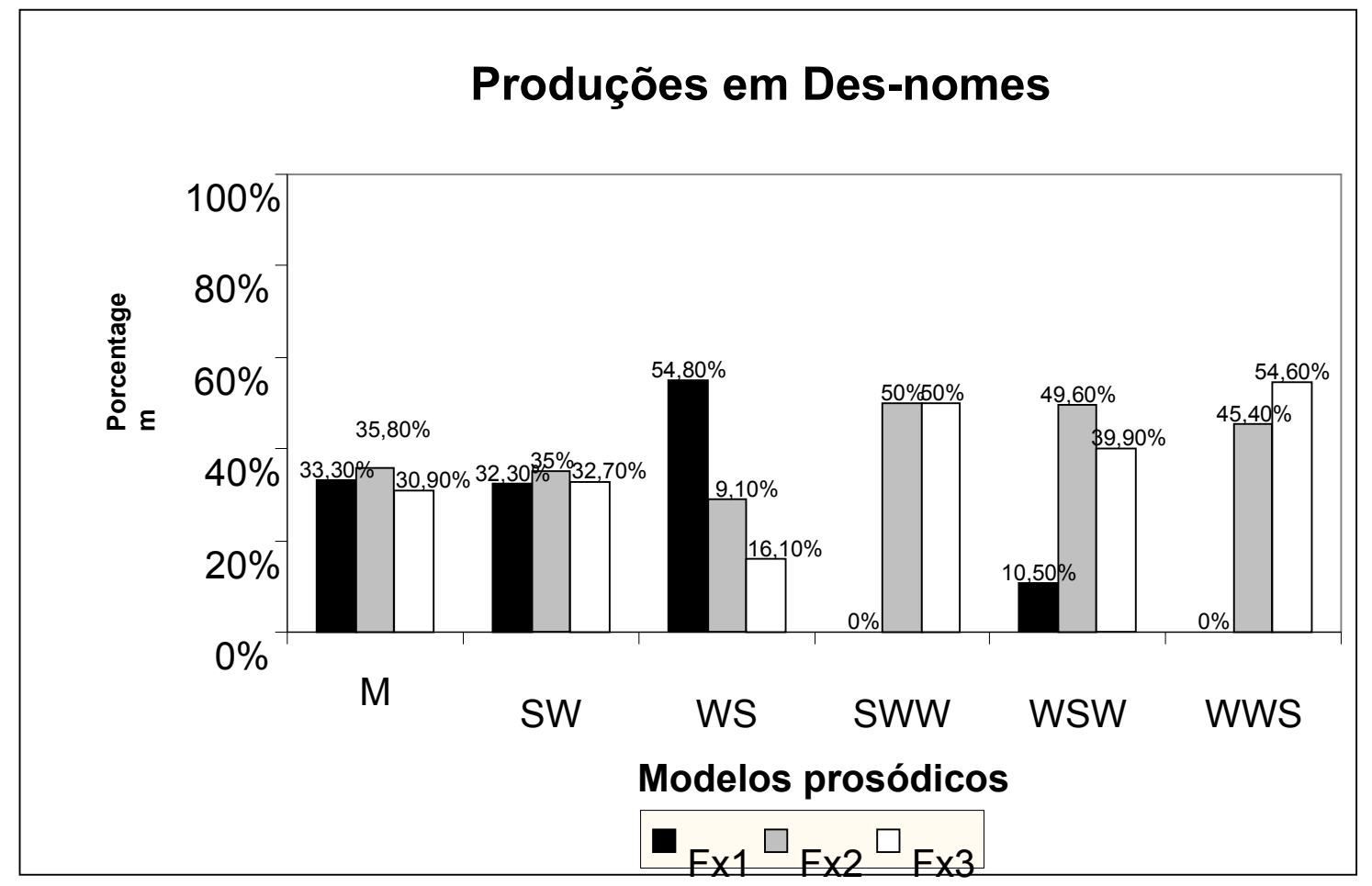

Gráfico 6: Modelos prosódicos em DES-nomes (total)

De acordo com o gráfico 6, as principais características de cada modelo foram: os monossílabos espalham-se quase que proporcionalmente nas três faixas, assim como as produções de SW. O modelo WS apresenta maior número de ocorrência em Fx1 que decresce até Fx3. Os trissílabos passam a ser produzidos em Fx2 e se estendem até Fx3. 


\subsubsection{Resultados: o papel dos verbos}

Na seção 5.2.2, foram apresentados os resultados referentes aos nomes de DES no intuito de compará-los com os de DEX, que contempla somente nomes também. Encontrou-se um papel importante do léxico particular na tendência iâmbica de DES (nomes), pois quando DES é analisado sem os dados desse tipo de léxico, encontra-se uma tendência trocaica aparente, mas com a presença do léxico particular, a tendência que favorece os troqueus não mais ocorre. Dessa maneira, resta saber qual o papel dos verbos na tendência iâmbica inicial atestada pelos observacionais, pois além de lidarem com léxico comum e particular, esses estudos levam em consideração duas classes de palavras (nomes e verbos), ao contrário do experimental de Rapp (1994) e o desta pesquisa que analisam apenas nomes.

Primeiramente, são apresentados os resultados descritivos dos verbos ${ }^{30}$ (DESverbos), esses resultados são seguidos pelos os de DES - verbos e nomes (sem léxico particular e erros de acento) e, por fim, DES (total: verbos, nomes, léxico particular e erros de acento).

A tabela 6 apresenta os resultados $400 \operatorname{dados}^{31}$ de DES-verbos.

\footnotetext{
${ }^{30}$ Como o objetivo desta pesquisa é encontrar e explicar os fatores que influenciam na discrepância entre os resultados dos estudos que adotam diferentes métodos, e não discutir a fundo a prosódia dos verbos na fala infantil, ela se prende à classe de palavra presente na análise dos dois métodos, a saber, a dos nomes. As informações referentes aos modelos prosódicos dos verbos são apresentadas brevemente e são apresentados os resultados descritivos a respeito da junção nome + verbo (sem léxico particular) e nome + verbo (com léxico particular). Para o contato com um estudo a respeito do desenvolvimento da prosódia dos verbos, ler Santos (2007).

${ }^{31} \mathrm{O}$ total de verbos foi de 416 dados, porém neste primeiro momento são desconsiderados os dados de léxico particular ( 4 criações lexicais e 12 produções familiares ) e nem de erros de acento, que não houve.
} 


\begin{tabular}{|c|c|c|c|c|c|c|}
\hline Alvo & Produção & Média & Desvio Padrão & Mínimo & Mediana & Máximo \\
\hline \multirow[t]{2}{*}{$\mathbf{S W}$} & $\mathbf{M}$ & 0,75 & 0,71 & 0,00 & 1,00 & 2,00 \\
\hline & SW & 5,80 & 3,36 & 1,00 & 5,00 & 14,00 \\
\hline \multirow[t]{2}{*}{$\mathbf{W S}$} & $\mathbf{M}$ & 1,80 & 1,60 & 0,00 & 2,00 & 6,00 \\
\hline & $\mathbf{W S}$ & 7,55 & 3,50 & 4,00 & 6,50 & 15,00 \\
\hline \multirow[t]{3}{*}{ SWW } & $\mathbf{M}$ & 0,00 & 0,00 & 0,00 & 0,00 & 0,00 \\
\hline & SW & 0,00 & 0,00 & 0,00 & 0,00 & 0,00 \\
\hline & SWW & 0,00 & 0,00 & 0,00 & 0,00 & 0,00 \\
\hline \multirow[t]{4}{*}{ WSW } & $\mathbf{M}$ & 0,00 & 0,00 & 0,00 & 0,00 & 0,00 \\
\hline & SW & 0,45 & 0,75 & 0,00 & 0,00 & 2,00 \\
\hline & WS & 0,00 & 0,00 & 0,00 & 0,00 & 0,00 \\
\hline & WSW & 1,95 & 2,06 & 0,00 & 1,50 & 7,00 \\
\hline \multirow[t]{3}{*}{ WWS } & M & 0,05 & 0,22 & 0,00 & 0,00 & 1,00 \\
\hline & WS & 0,50 & 0,68 & 0,00 & 0,00 & 2,00 \\
\hline & WWS & 1,15 & 1,26 & 0,00 & 1,00 & 5,00 \\
\hline
\end{tabular}

Tabela 6: Resultados descritivos DES-verbos

Nos dados de DES-verbos (sem léxico particular e erros de acento), o modelo prosódico que foi mais produzido como monossílabo após apagamento foi WS $(\overline{\mathrm{x}}=1,80)$. O dissílabo mais produzido foi WS $(\overline{\mathrm{x}}=7,55)$ seguido por $\mathrm{SW}(\overline{\mathrm{x}}=5,80)$, porém após o teste de qui-quadrado de aderência, constatou-se que as duas médias não são significativamente diferentes (Valor-P > 0,05). No que se refere aos trissílabos, não houve caso de SWW (com ou sem apagamento), apenas de WSW, que foi o trissílabo mais produzido de acordo com a forma alvo $(\bar{x}=1,95)$ e sofreu apagamento que favoreceu o modelo $\mathrm{SW}(\overline{\mathrm{x}}=0,45)$, e de WWS que sofreu apagamento em direção a WS $(\overline{\mathrm{x}}=0,50)$. A seguir, são apresentados alguns exemplos dos dados considerados para a obtenção desses resultados: 
$\mathbf{S W}>\mathbf{M}$
(35) $[\mathrm{ba}]$
'bate'
$1 ; 5$
(36) $[\mathrm{k} \varepsilon]$
'quero'
$1 ; 7$

SW $>$ SW

$\begin{array}{lll}\text { (37) ['pe.ge] } & \text { 'pega' } & 1 ; 7 \\ \text { (38) ['to.ke] } & \text { 'toca' } & 1 ; 9\end{array}$

WS $>$ M

$\begin{array}{lll}\text { (39) } \text { [bi] } & \text { 'abrir' } & 1 ; 6 \\ \text { (40 ) [tão] } & \text { 'estão' } & 2 ; 4\end{array}$

WS $>$ WS

$\begin{array}{lll}\text { (41) [fa.'la] } & \text { 'falar' } & 1 ; 5 \\ \text { (42) [ko.'to] } & \text { 'cortou' } & 2 ; 0\end{array}$

WSW $>$ SW
(43) ['pej.te]
'aperta' 2;0
(44) ['pe.sI ]
'parece' 2;3

WSW > WSW
(45) [ $\int$ o.'ã.du]
'chorando'
$2 ; 1$
(46) [to.'kã.nu]
'tocando' 2;2 
$\mathbf{W W S}>\mathbf{M}$

(47) [bo] 'acabou' $1 ; 11$

\section{WWS $>$ WS}

$\begin{array}{lll}\text { (48) }[\text { ka.'bo] } & \text { 'acabou' } & 1 ; 9 \\ \text { (49) }[\text { ko.'i] } & \text { 'colorir' } & 2 ; 8\end{array}$

\section{WWS $>$ WWS}
(50) [kõ.si.'gi]
'consegui' 2;2
(51) [ma. Su.'ko]
'machucou' 2;3

Ao longo das faixas, na comparação entre as médias de SW $>$ SW e WS $>$ WS, notase que o modelo WS predominou, aparentemente, nas três faixas. No entanto, após o teste de qui-quadrado com aderência, constatou-se que em nenhum dos intervalos as médias de SW e WS foram significativamente diferentes (Valor-P $>0,05$ ); por isso pode ser afirmado que apenas houve uma tendência aparente de WS:

\begin{tabular}{|c|c|c|c|}
\hline Faixas & SW & WS & Valor-P \\
\hline Fx1 & 6,2 & 7,75 & $>0,05$ \\
\hline Fx2 & 6,5 & 6,83 & $>0,05$ \\
\hline Fx3 & 5,3 & 8,00 & $>0,05$ \\
\hline
\end{tabular}

Tabela 7: $S W$ e WS nas faixas etárias de DES-verbos (total)- teste qui-quadrado

Foi realizado o teste-F e o valor-P obtido foi o mesmo em cada faixa etária.

No conjunto total de verbos (416 dados), não houve nenhum caso de erro de acento, e os dados de léxico particular foram pouquíssimos para exercerem alguma influência no 
modelo prosódico predominante nos verbos: 4 casos de criações lexicais $-0,9 \%$ dos dados - 3 WS e 1 WWS; 12 casos de produções familiares - 2,8\% dos dados - todos WS. Alguns exemplos de léxico particular:

\section{Criação lexical}

$\begin{array}{lll}\text { (52) [ne.'ne] } & \text { 'comer' } & 1 ; 5 \\ \text { (53) ['ki.ne] } & \text { 'brincar' } & 1 ; 9\end{array}$

\section{Produção familiar}

$\begin{array}{lll}\text { (53) [na.'na] } & \text { 'dormir' } & 1 ; 5 \\ \text { (54) [na.'nã.dv] } & \text { 'dormindo' } & 1 ; 8\end{array}$

No total de dados de verbos, considerando os erros de acento e léxico particular, foi observada a predominância de WS; no entanto, após o teste qui-quadrado das médias (SW $\overline{\mathrm{x}}=6,25$, WS $\overline{\mathrm{x}}=8,05)$ e teste-F dos números absolutos, observou-se que essa predominância não é significativa em relação ao modelo SW.

\subsubsection{Resultados: nomes com verbos (sem léxico particular)}

Os resultados presentes na tabela 8 contemplam dados de nomes (638 dados) e verbos em DES (400 dados) conjuntamente (total de 1038 dados) sem considerar o léxico particular: 


\begin{tabular}{|c|c|c|c|c|c|}
\hline Produção & Média & Desvio Padrão & Mínimo & Mediana & Máximo \\
\hline M & 8,60 & 3,33 & 2,00 & 8,50 & 14,00 \\
\hline SW & 22,35 & 8,39 & 4,00 & 23,50 & 35,00 \\
\hline WS & 22,45 & 11,08 & 9,00 & 21,00 & 50,00 \\
\hline SWW & 0,10 & 0,30 & 0,00 & 0,00 & 1,00 \\
\hline WSW & 8,30 & 6,95 & 0,00 & 8,50 & 22,00 \\
\hline WWS & 1,70 & 1,80 & 0,00 & 1,00 & 6,00 \\
\hline
\end{tabular}

Tabela 8: Resultados descritivos de DES-nomes/verbos (sem léxico particular)

Como a tabela apresenta, o trissílabo mais produzido foi o WSW $(\overline{\mathrm{x}}=8,30)$. Os dois modelos dissilábicos apresentam médias bem próximas do total de produção $(\mathrm{SW} \overline{\mathrm{x}}=22,35$; WS $\bar{x}=22,45)$, e por essa razão não são significativamente diferentes (Valor-P > 0,05), o que foi confirmado com o teste qui-quadrado e o teste-F (Valor-P > 0,05).

As médias dos modelos SW e WS, se calculadas por faixa, se distribuem da seguinte forma:

\begin{tabular}{|c|c|c|c|}
\hline Faixas & SW & WS & Valor-P \\
\hline Fx1 & 19,50 & 27,75 & $>0,05$ \\
\hline Fx2 & 26,33 & 21,00 & $>0,05$ \\
\hline Fx3 & 22,16 & 16,83 & $>0,05$ \\
\hline
\end{tabular}

Tabela 9: $S W$ e WS nas faixas etárias de DES-nomes/verbos (sem léxico particular)- teste qui-quadrado

Como a tabela 9 apresenta, nenhuma das diferenças entre os dois modelos nas diferentes faixas etárias foi significativa. No entanto, o modelo WS predominou aparentemente em Fx1. 


\subsubsection{Resultados: nomes com verbos (total)}

Os resultados presentes na tabela 10 contemplam todos os dados de nomes (761 dados) e verbos em DES (416 dados), que totalizam 1177 dados.

\begin{tabular}{|c|c|c|c|c|c|}
\hline Produção & Média & Desvio Padrão & Mínimo & Mediana & Máximo \\
\hline M & 8,60 & 3,31 & 2,00 & 8,5 & 14,00 \\
\hline SW & 22,95 & 8,03 & 4,00 & 24,00 & 35,00 \\
\hline WS & 23,50 & 12,18 & 9,00 & 21,50 & 50,00 \\
\hline SWW & 0,10 & 0,30 & 0,00 & 0,00 & 1,00 \\
\hline WSW & 8,60 & 6,75 & 0,00 & 8,50 & 22,00 \\
\hline WWS & 1,70 & 1,80 & 0,00 & 1,00 & 6,00 \\
\hline
\end{tabular}

Tabela 10: Resultados descritivos de DES-nomes/verbos (total)

Como a tabela 10 apresenta, o trissílabo mais produzido foi o WSW $(\overline{\mathrm{x}}=8,60)$. Os dois modelos dissilábicos apresentam médias bem próximas do total de produção ( $\mathrm{SW} \overline{\mathrm{x}}=$ 22,95 ; WS $\bar{x}=23,50$ ), e por essa razão não são significativamente diferentes, o que foi verificado com o teste qui-quadrado e teste-F (Valor-P $>0,05$ ).

As médias dos modelos SW e WS, se calculadas por faixa, se distribuem da seguinte forma:

\begin{tabular}{|c|c|c|c|}
\hline Faixas & SW & WS & Valor-P \\
\hline Fx1 & 19,50 & 29,75 & $>0,05$ \\
\hline Fx2 & 26,20 & 21,00 & $>0,05$ \\
\hline Fx3 & 24,16 & 15,66 & $>0,05$ \\
\hline
\end{tabular}

Tabela 11: SW e WS nas faixas etárias de DES-nomes/verbos (total) - teste qui-quadrado 
Como a tabela 11 apresenta, nenhuma das diferenças entre os dois modelos nas diferentes faixas etárias são significativas. No entanto, em Fx1 há uma tendência iâmbica aparente. O teste-F apresentou os mesmos resultados em relação ao valor-P.

\subsection{Resumo}

Os resultados totais de DES (nomes, verbos, léxico particular e comum) apontaram uma tendência iâmbica nos dados, que é aparente, pois o teste estatístico que comparou as médias dos dois modelos, a saber, o trocaico e o iâmbico, mostrou que elas não são diferentes significativamente (cf. tabela 11). Dessa maneira, o resultado obtido na análise de DES corrobora o que tem sido afirmado pelos demais estudos observacionais (SANTOS, 2006, 2007; BONILHA, 2004; BAIA, 2006), isto é, predominância de iambos.

Todavia, quando DES não foi analisado na sua totalidade, a tendência prosódica não foi mesma. Ao analisar apenas DES-nomes com o léxico particular ausente e presente (cf. tabela 3), houve uma predominância de troqueus que, embora não significativa estatisticamente, vai ao encontro do que se observou em DEX. No entanto, quando esses

mesmos dados foram divididos em três faixas etárias, com o léxico particular presente, houve predominância de iambos em Fx1, e com o léxico particular ausente, houve predominância de troqueus nessa faixa etária (cf. tabela 4). Portanto, a tendência iâmbica, mesmo que aparente, ocorreu em DES-nomes quando o léxico particular foi considerado.

DES-verbos foram predominantemente iâmbicos com ou sem a presença do léxico particular (cf. tabela 6 e 7). Devido ao padrão prosódico que se sobressaiu nas produções verbais iniciais, quando DES-nomes foi analisado juntamente com DES-verbos sem a presença do léxico particular, houve uma leve predominância de iambos (cf. tabela 8). Essa 
tendência prosódica, embora aparente, ficou acentuada quando esses dados foram analisados em faixas, pois em Fx1 houve o predomínio de iambos (cf. tabela 9). Essa mesma tendência permaneceu quando os dados de léxico particular foram inseridos (cf. tabela 10 e 11).

No decorrer da análise, notou-se que o modelo WSW, quando sofreu apagamento, foi mais produzido como WS em DES-nomes e SW em DES-verbos. Só houve caso de apagamento em SWW em DES-nomes, no qual o modelo SW predominou; e o modelo WWS sofreu apagamento favorecendo a produção de WS nas duas classes de palavras.

Os dados de léxico particular em DES-nomes e DES-verbos foram, predominantemente, iâmbicos. Além disso, os dois casos de erros de acento, que ocorreram apenas em DES-nomes, favoreceram o pé iâmbico.

Cabe ressaltar que, curiosamente, enquanto houve uma tendência iâmbica nos dados com erros de acento e léxico particular, WS foi o modelo que mais sofreu apagamento em DES-verbos e SW em DES-nomes. 


\section{DISCUSSÃO}

Neste estudo, foram empregadas duas metodologias de estudo (experimental e observacional) no intuito de comparar os resultados e verificar o que pode estar influenciando a discrepância presente nos resultados de estudos que lidam com a aquisição da prosódia. O quadro encontrado com os resultados de DEX e DES foi o mesmo que tem sido apresentado pela literatura sobre o PB: o estudo experimental apontou uma tendência trocaica, enquanto que o estudo observacional apontou uma tendência iâmbica. Os resultados mostram que o léxico contemplado em cada tipo de estudo (léxico comum vs léxico particular) e a classe de gramatical (nomes vs verbos) desempenham um papel importante na tendência prosódica inicial. Dessa maneira, a explicação para a discrepância encontrada entre os resultados dos estudos que lidam com diferentes métodos, parece estar no design do método no que se refere ao tipo de léxico e classe de palavra contemplados.

Foram aplicados dois testes estatísticos para verificar a significância da diferença entre os números de produção de SW e WS, a saber, o teste qui-quadrado e o teste-F. Como foi apresentado ao longo da exposição dos resultados, na maior parte dos casos, os dois testes apresentaram um valor-P menor que 0,05 ; logo não houve significância estatística nos valores apresentados por eles. Porém, nesta discussão, apesar de serem mencionados os resultados de tais testes, leva-se em conta a tendência aparente que se pode observar na comparação das médias. Isto porque a maior parte dos trabalhos do PB (exceto SANTOS, 2007) apresentam resultados quantitativos sem a utilização de testes de verificação de significância. Como o objetivo central desta dissertação de mestrado é fornecer uma

explicação para a discrepância entre os resultados de estudos experimentais e 
observacionais, e tais estudos defendem suas conclusões com base em resultados sem verificação estatística, mantém-se a mesma maneira de apontar a predominância, i.e. com base em tendências aparentes.

Como apresentado no capítulo 2, estudos que adotam diferentes métodos apresentam diferentes resultados. Foi visto que Santos (2001) e Bonilha (2004), analisando dados naturalísticos, apontam uma tendência iâmbica, enquanto Rapp (1994), usando dados experimentais, aponta uma tendência trocaica. Dessa maneira, levantou- se a hipótese 1, segundo a qual o método utilizado pode interferir nos resultados. Essa primeira hipótese foi confirmada, pois confrontando as tabelas 5 e 6 de DEX (capítulo 4) e as 10 e 11 de DES (capítulo 5) - cf. Tabela 1 abaixo -, que apresentam resultados da análise de todos os dados contemplados na análise de DES e DEX, nota-se que o método utilizado interfere nos resultados, pois foi encontrada uma predominância trocaica em $\operatorname{DEX}(\overline{\mathrm{x}}=13,38)$ e iâmbica em DES $(\overline{\mathrm{x}}=23,50)$ no que se refere aos dados totais.

\begin{tabular}{|l|l|l|l|l|l|}
\hline \multicolumn{3}{|c|}{ Dados da tabela 5 e 6 de DEX } & \multicolumn{3}{c|}{ Dados da Tabela 10 e 11 de DES } \\
\hline \multicolumn{3}{|c|}{ SW - Total: 13,38 } & \multicolumn{3}{c|}{ SW - Total: 22,95} \\
\hline Fx1: 13,76 & Fx2: 14,15 & Fx3: 12,43 & Fx1: 19,50 & Fx2: 26,20 & Fx3: 24,16 \\
\hline \multicolumn{3}{|c|}{ WS - Total: 9,92} & \multicolumn{3}{c|}{ WS - Total: 23,50 } \\
\hline Fx1: 9,5 & Fx2: 9,92 & Fx3: 10,56 & Fx1: 29,75 & Fx2: 21,00 & Fx3: 15,66 \\
\hline
\end{tabular}

Tabela 1: Dados das tabelas 5 e 6 de DEX e das tabelas 10 e 11 de DES

Com base na tabela 1 , observa-se a predominância de $\operatorname{SW}$ em $\operatorname{DEX}(\overline{\mathrm{x}}=13,38)$ e a de WS em DES $(\bar{x}=23,50)$ no que se refere aos dados totais. Em relação às faixas, $\mathrm{SW}$ predomina nas três faixas de DEX $(\operatorname{Fx} 1 \bar{x}=13,76 / F \times 2 \bar{x}=14,5 / F x 3 \bar{x}=12,43)$, enquanto 
que SW predomina apenas nas Fx2 $(\overline{\mathrm{x}}=26,20)$ e Fx3 $(\overline{\mathrm{x}}=24,16)$ de DES, e WS predomina em $\operatorname{Fx} 1(\bar{x}=29,75)$

Tais observações vão ao encontro do que tem sido apresentado pela literatura, que se prende ao período contemplado em Fx1, na investigação acerca do modelo prosódico inicial. Assim como os estudos naturalísticos afirmam (cf. SANTOS, 2006, 2007; BAIA, 2006), houve predominância de iambos em Fx1 e no total de DES. E o que foi encontrado na análise de DEX, corrobora o que é afirmado por Rapp (1994) no seu estudo experimental. Logo pode-se afirmar que o que ocasiona a discrepância entre os resultados desses estudos sobre o PB é o design do método.

Como foi apresentado no capítulo 2, uma característica do estudo experimental de Rapp (1994) é o uso apenas do léxico comum no inventário lexical do experimento. Essa mesma característica foi mantida em DEX a fim de se verificar o papel desse léxico na predominância trocaica afirmada pela autora. Enquanto esses dois estudos experimentais contemplam apenas dados de léxico comum, como já foi discutido, os estudos observacionais contemplam os dados na sua totalidade, incluindo, dessa maneira, dados de léxico particular (produções familiares e criações lexicais). O léxico particular, como observado por Santos $(2006,2007)$ e Baia (2006), é predominantemente iâmbico no PB. Devido a essa característica do léxico particular, foi levantada a hipótese 2, segundo a qual, dado que o léxico particular desempenha um papel importante na tendência iâmbica encontrada pelos estudos observacionais, a ausência dele nos dados naturalísticos faz com que os demais dados apontem a mesma tendência encontrada pelo experimental (trocaica). Após análise dos dados, essa hipótese também foi confirmada. Apesar de ter havido nos dados totais de DES a predominância de troqueus $(\overline{\mathrm{x}}=16,70)$, como a tabela 2 apresenta a 
seguir, a hipótese 2 está correta, pois nota-se que em Fx1 (o intervalo etário de mais interesse para nossa análise por ser o contemplado pela literatura em geral), há um predomínio de iambos nos dados totais, i.e. aquele que soma léxico comum e particular. No entanto, quando o léxico particular é desconsiderado, a tendência iâmbica não permanece, e o que se verifica em DES- nomes é uma predominância de troqueus em Fx1.

\begin{tabular}{|l|l|l|l|l|l|l|l|l|l|}
\hline \multicolumn{9}{|c|}{ Dados da tabela 4 de DES-nomes } \\
\hline \multicolumn{3}{|c|}{ Sem o léxico particular } & \multicolumn{5}{c|}{ Total } \\
\hline SW & Fx1: & Fx2: & Fx3: & Total: & SW & Fx1: & Fx2: & Fx3: & Total: \\
& $\mathbf{1 2 , 2 5}$ & $\mathbf{1 9 , 3 3}$ & $\mathbf{1 8 , 1 6}$ & $\mathbf{1 6 , 1 5}$ & & 13,5 & $\mathbf{1 9 , 5}$ & $\mathbf{1 8 , 1}$ & $\mathbf{1 6 , 7 0}$ \\
\hline WS & Fx1: & Fx2: & Fx3: & Total: & WS & Fx1: & Fx2: & Fx3: & Total: \\
& 10,25 & 12,16 & 6,00 & 9,55 & & $\mathbf{1 9 , 5}$ & 13,6 & 7,5 & 14,05 \\
\hline
\end{tabular}

Tabela 2: Dados da tabela 4 de DES

Como a tabela 2 apresenta, a discrepância entre DES e DEX ocorre em Fx1, em que há maior emergência de iambos nos dados totais $(\bar{x}=19,5)$ e de troqueus no conjunto de dados que deixa de contemplar o léxico particular $(\bar{x}=12,25)$. Dessa forma, estudos que adotam diferentes métodos, que apesar de lidarem com a mesma classe gramatical (nomes) contemplam diferentes tipos de léxico (comum versus particular), podem não apresentar o mesmo resultado devido ao inventário lexical contemplado. Acredita-se que o estudo que abrange toda a possibilidade de produção lexical infantil, a saber, o observacional, é o que pode afirmar uma predominância prosódica geral. Os estudos experimentais - o aqui realizado e o de Rapp (1994) - por lidarem apenas com dados de léxico comum, abordam a proeminência prosódica presente apenas nesse tipo de produção, e devem evitar, portanto, fazer afirmações sobre uma tendência geral a respeito da aquisição prosódica do PB. 
Este tipo de cuidado metodológico não é necessário apenas no PB, mas no estudo de todas as línguas que foram verificadas no que se refere ao modelo prosódico inicial da fala. Retomando os estudos que defendem o troqueu como modelo prosódico default (cf. ALLEN \& HAWKINS, 1980; GERKEN, 1994; DEMUTH, 1995, 1996; ARCHIBALD, 1995; ADAM \& BAT-EL, 2007), observa-se que a maior parte deles não explicita que tipo de léxico e categoria gramatical foram analisados. Alguns desses estudos são qualitativos (cf. ARCHIBALD, 1995; DEMUTH, 1995; 1996), outros são quantitativos, mas não explicitam o tipo de dado analisado (ALLEN \& HAWKINS, 1980; ADAM \& BAT-EL, 2007); no entanto, há os que deixam a entender que contemplaram os dados na sua totalidade (FIKKERT, 1994; PRIETO, 2005) ou, no caso do estudo de Gerken (1994), que utiliza logatomas no experimento, o que pode excluir a interferência da classe gramatical ou tipo de léxico.

Nota-se, então, que a maior parte dos estudos que defende o troqueu como modelo prosódico inicial não apresenta o mesmo tipo de controle metodológico no que se refere ao tipo de léxico contemplado, além de haver tanto estudos qualitativos quanto quantitativos. Deve-se destacar o estudo de Gerken (1994) que analisa a produção de logatomas, o qual, em princípio, pode ser entendido como excluindo a interferência da classe gramatical ou tipo de léxico, e mesmo assim encontra mais ocorrências de troqueus. Duas considerações se colocam: Hochberg (1988b) realiza o mesmo tipo de estudo com o espanhol e não encontra a mesma tendência, ocorrendo o que a autora chama de início neutro. Em segundo lugar, não é apresentada uma descrição do experimento de Gerken. Não há como saber se os logatomas foram utilizados como puras repetições ("repita xxx pra mim"), ou se os 
logatomas eram utilizados como nomes de brinquedos, por exemplo - e neste caso estavam claramente associados a uma classe gramatical, os nomes. ${ }^{32}$

Como já foi adiantado nos parágrafos acima, os estudos experimentais e observacionais do PB não diferem apenas no que se refere ao tipo de léxico (comum versus particular), mas também no que se refere à classe gramatical. Dessa maneira, levantou-se a hipótese 3, segundo a qual, não apenas o tipo de léxico (particular ou comum) interfere nos resultados, mas a classe de palavra contemplada em cada método também. Após a análise dos dados, essa hipótese foi confirmada. Observe a tabela 3 (a partir das tabelas 3, 4, 7, 8, 9, 10 de DES):

\begin{tabular}{|c|c|c|c|c|c|c|c|c|c|c|c|}
\hline \multicolumn{12}{|c|}{ Dados das tabelas 3, 4, 7, 8, 910 de DES } \\
\hline \multicolumn{3}{|c|}{$\begin{array}{r}\text { Nomes } \\
\text { (SLP) }\end{array}$} & \multicolumn{3}{|c|}{$\begin{array}{c}\text { Nomes + Verbos } \\
\text { (SLP) }\end{array}$} & \multicolumn{3}{|c|}{$\begin{array}{r}\text { Nomes } \\
\text { (total) }\end{array}$} & \multicolumn{3}{|c|}{$\begin{array}{c}\text { Nomes + Verbos } \\
\text { (total) }\end{array}$} \\
\hline \multicolumn{3}{|c|}{ SW- Total: 16,15} & \multicolumn{3}{|c|}{ SW- Total: 22,35} & \multicolumn{3}{|c|}{ SW- Total: $\mathbf{1 6 , 7 0}$} & \multicolumn{3}{|c|}{ SW- Total: 22,95} \\
\hline $\begin{array}{l}\text { Fx1: } \\
12,25\end{array}$ & $\begin{array}{l}\text { Fx2: } \\
19,33\end{array}$ & $\begin{array}{l}\text { Fx3: } \\
18,16\end{array}$ & $\begin{array}{l}\text { Fx1: } \\
19,50\end{array}$ & $\begin{array}{l}\mathrm{F} \times 2: \\
26,33\end{array}$ & $\begin{array}{l}\mathrm{F} \times 3: \\
22,16\end{array}$ & $\begin{array}{l}\text { Fx1: } \\
13,5\end{array}$ & $\begin{array}{l}\text { Fx2: } \\
19.5\end{array}$ & $\begin{array}{l}\text { Fx3: } \\
18.1\end{array}$ & $\begin{array}{l}\text { Fx1: } \\
19,50\end{array}$ & $\begin{array}{l}\mathrm{F} \times 2: \\
26,20\end{array}$ & $\begin{array}{l}\text { Fx3: } \\
24.16\end{array}$ \\
\hline \multicolumn{3}{|c|}{ WS- Total: 9,55 } & \multicolumn{3}{|c|}{ WS- Total: 22,45} & \multicolumn{3}{|c|}{ WS- Total: 14,05} & \multicolumn{3}{|c|}{ WS- Total: 23,50} \\
\hline $\begin{array}{l}\text { Fx1: } \\
10,25\end{array}$ & $\begin{array}{l}\text { Fx2: } \\
12,16\end{array}$ & $\begin{array}{l}\text { Fx3: } \\
6,00\end{array}$ & $\begin{array}{l}\text { Fx1: } \\
27,75\end{array}$ & $\begin{array}{l}\text { Fx2: } \\
21,00\end{array}$ & $\begin{array}{l}\text { Fx3: } \\
16,83\end{array}$ & $\begin{array}{l}\text { Fx1: } \\
19,5\end{array}$ & $\begin{array}{l}\text { Fx2: } \\
13,6\end{array}$ & $\begin{array}{l}\text { Fx3: } \\
7,5\end{array}$ & $\begin{array}{l}\text { Fx1: } \\
29,75\end{array}$ & $\begin{array}{l}\text { Fx2: } \\
21,00\end{array}$ & $\begin{array}{l}\text { Fx3: } \\
15,66\end{array}$ \\
\hline
\end{tabular}

Tabela 3: Dados das tabelas 3, 4, 7, 8, 9 e 10 de DES

Observando a tabela 3, nota-se que quando analisados nomes e verbos juntamente, na soma das três faixas, há a predominância de iambos tanto quando o léxico particular é considerado $(\bar{x}=23,50)$ como quando está ausente $(\bar{x}=22,45)$. Dessa maneira, os verbos parecem desempenhar um papel importante na predominância iâmbica em DES, pois quando os nomes são analisados isoladamente há a predominância de SW no total de dados

\footnotetext{
${ }^{32}$ Este tipo de estudo está, no momento, em andamento por Baia \& Santos.
} 
$(\bar{x}=16,70)$, enquanto que quando nomes e verbos são analisados juntamente, o domínio passa a ser de WS. Como tal resultado poderia ocorrer devido à presença do léxico particular nos dados, que é predominantemente iâmbico (e foi mostrado que ele tem papel importante na predominância de iambos em DES), analisou-se também os resultados sem o léxico particular. Desconsiderando o léxico particular, foi encontrada uma predominância de SW em DES-nomes $(\bar{x}=16,15)$ que não prevalece quando os verbos são inseridos $(\bar{x}=$ 22,35). Cabe ressaltar que todas essas predominâncias referentes ao total de dados estão presentes, majoritariamente, em Fx1.

A presença de verbos também influencia na predominância de iambos em DES. Cabe ressaltar que os dados de verbos, quando analisados separadamente, apresentaram predominância de iambos, como foi apresentado no capítulo 5 (cf. Tabela 7). Santos (2007), confirmando o estudo de Kato (1996), explica que esse comportamento dos verbos na fala inicial ocorre porque as crianças adquirem, primeiramente, a forma finita ('brincar', 'jogar'), a terceira pessoa do singular do pretérito perfeito ('acabou', 'jogou'); as quais são seguidas pela terceira pessoa do singular do presente ('joga', 'fala'), pelo imperativo ('fala!', 'corra!'), pelo gerúndio ('brincando', 'pulando'), etc. Assim, Santos (2007) explica que “(...) embora o valor default de acentuação dos verbos seja o troqueu, razões morfosintáticas fazem com quem a produção de iambos supere a de troqueus” (p.195).

Em resumo, as três hipóteses deste estudo foram confirmadas e a discrepância entre os resultados dos estudos observacional e experimental é explicada por meio do design do método aplicado, que abrange o tipo de léxico contemplado e a classe de palavra. Esses dois fatores influenciam no resultado devido ao comportamento prosódico diferenciado. 
Acredita-se que o estudo experimental de Rapp (1994) e o que foi conduzido aqui apresentam desvantagem em relação aos estudos observacionais por não terem obtido suas conclusões com base na análise do léxico infantil total. No entanto, isso não significa que um estudo com o método experimental seja inapropriado em uma pesquisa acerca do modelo prosódico; ao contrário, o método é válido como o observacional, porém precisa haver a busca por meios que contemplem o inventário lexical infantil na sua totalidade, já que a tendência levantada até então pelos estudos experimentais referia-se apenas aos nomes. Assim, é crucial que a análise ultrapasse o que foi chamado de léxico comum nesta análise, léxico que deixa de lado as palavras mais freqüentes no dia a dia das crianças (produções familiares) e as 'brincadeiras' de nomeação (criações lexicais).

O próximo quadro confronta os resultados apresentados por ambos os estudos aqui conduzidos: 


\begin{tabular}{|c|c|c|c|c|c|c|c|}
\hline $\begin{array}{l}\text { Tipo de dado } \\
\text { predominante }\end{array}$ & DEX & $\begin{array}{l}\text { DES-nomes } \\
\text { (léxico } \\
\text { comum) }\end{array}$ & $\begin{array}{l}\text { DES-nomes } \\
\text { (Total) }\end{array}$ & $\begin{array}{l}\text { DES-verbos } \\
\text { (léxico } \\
\text { comum) }\end{array}$ & $\begin{array}{l}\text { DES-verbos } \\
\text { (total) }\end{array}$ & $\begin{array}{l}\text { DES-nomes } \\
\text { e verbos } \\
\text { (léxico } \\
\text { comum) }\end{array}$ & $\begin{array}{l}\text { DES } \\
\text { (total) }\end{array}$ \\
\hline Tamanho da palavra & $\begin{array}{l}\text { Dissílabo } \\
(\mathrm{Fx} 1, \mathrm{Fx} 2, \mathrm{Fx} 3)\end{array}$ & $\begin{array}{l}\text { Dissílabo } \\
(\mathrm{Fx} 1, \mathrm{Fx} 2, \mathrm{Fx} 3)\end{array}$ & $\begin{array}{l}\text { Dissílabo } \\
(\mathrm{Fx} 1, \mathrm{Fx} 2, \mathrm{Fx} 3)\end{array}$ & $\begin{array}{l}\text { Dissílabo } \\
(\mathrm{Fx} 1, \mathrm{Fx} 2, \mathrm{Fx} 3)\end{array}$ & $\begin{array}{l}\text { Dissílabo } \\
(\mathrm{Fx} 1, \mathrm{Fx} 2, \mathrm{Fx} 3)\end{array}$ & $\begin{array}{l}\text { Dissílabo } \\
(\mathrm{Fx} 1, \mathrm{Fx} 2, \mathrm{Fx} 3)\end{array}$ & $\begin{array}{l}\text { Dissílabo } \\
(\mathrm{Fx} 1, \mathrm{Fx} 2, \mathrm{Fx} 3)\end{array}$ \\
\hline Modelo dissilábico & $\begin{array}{l}\text { SW } \\
(\mathrm{Fx} 1, \mathrm{Fx} 2, \mathrm{Fx} 3)\end{array}$ & $\begin{array}{l}\text { SW } \\
(\mathrm{Fx} 1, \mathrm{Fx} 2, \mathrm{Fx} 3)\end{array}$ & $\begin{array}{l}\text { WS (Fx1) / } \\
\text { SW (Fx2,Fx3) }\end{array}$ & $\begin{array}{l}\text { WS } \\
(\mathrm{Fx} 1, \mathrm{Fx} 2, \mathrm{Fx} 3)\end{array}$ & $\begin{array}{l}\text { WS } \\
(\mathrm{Fx} 1, \mathrm{Fx} 2, \mathrm{Fx} 3)\end{array}$ & $\begin{array}{l}\text { WS (Fx1), } \\
\text { SW (Fx2, Fx3) }\end{array}$ & $\begin{array}{l}\text { WS (Fx1), } \\
\text { SW(Fx2, Fx3) }\end{array}$ \\
\hline $\begin{array}{l}\text { Modelo que mais } \\
\text { passou a ser } \\
\text { monossílabo após } \\
\text { apagamento } \\
\end{array}$ & $\begin{array}{l}\text { WS } \\
(\mathrm{Fx} 1, \mathrm{~F} \times 2, \mathrm{Fx} 3)\end{array}$ & $\begin{array}{l}\text { SW } \\
(\mathrm{Fx} 1, \mathrm{Fx} 2, \mathrm{Fx} 3)\end{array}$ & $\begin{array}{l}\text { SW } \\
(\mathrm{Fx} 1, \mathrm{Fx} 2, \mathrm{Fx} 3)\end{array}$ & $\begin{array}{l}\text { WS } \\
(\mathrm{Fx} 1, \mathrm{Fx} 2, \mathrm{Fx} 3)\end{array}$ & $\begin{array}{l}\mathrm{WS} \\
(\mathrm{Fx} 1, \mathrm{Fx} 2, \mathrm{Fx} 3)\end{array}$ & $\begin{array}{l}\text { SW } \\
(\mathrm{Fx} 1, \mathrm{Fx} 2, \mathrm{Fx} 3)\end{array}$ & $\begin{array}{l}\text { SW } \\
(\mathrm{Fx} 1, \mathrm{Fx} 2, \mathrm{Fx} 3)\end{array}$ \\
\hline $\begin{array}{c}\text { Apagamento em } \\
\text { WSW }\end{array}$ & $\begin{array}{l}\text { SW } \\
(\mathrm{Fx} 1, \mathrm{Fx} 2, \mathrm{Fx} 3)\end{array}$ & WS (Fx1) & WS (Fx1) & SW (Fx1) & SW (Fx1) & WS (Fx1) & WS (Fx1) \\
\hline Erros de acento & $\begin{array}{l}\mathrm{SW}>\mathrm{WS} \\
(\mathrm{Fx} 1, \mathrm{Fx} 2)\end{array}$ & ------------------ & $\begin{array}{l}\text { SW }>\text { WS } \\
(\mathrm{Fx} 1)\end{array}$ & ------------------ & ------------------ & ------------------- & $\begin{array}{l}\text { SW }>\text { WS } \\
(\mathrm{Fx} 1)\end{array}$ \\
\hline Criações lexicais & $\begin{array}{l}\text { WS(Fx1)/ } \\
\text { SW (Fx2) }\end{array}$ & |----------------- & WS (Fx1) & ------------------ & WS (Fx1) & ------------------- & WS (Fx1) \\
\hline Produções familiares & -------------- & & $\begin{array}{l}\text { WS } \\
(\mathrm{Fx} 1, \mathrm{Fx} 2, \mathrm{Fx} 3)\end{array}$ & --------------- & $\begin{array}{l}\mathrm{WS} \\
(\mathrm{Fx} 1, \mathrm{Fx} 2)\end{array}$ & $\begin{array}{l}----- \\
--1\end{array}$ & $\begin{array}{l}\text { WS } \\
(\mathrm{Fx} 1, \mathrm{Fx} 2, \mathrm{Fx} 3)\end{array}$ \\
\hline
\end{tabular}


Quadro 1: Quando comparativo dos resultados de DEX e DES 
Observa-se que nos dois tipos de estudos, na faixa etária aqui analisada, as produções dissilábicas foram predominantes. No que se refere a DEX, os dados de léxico particular e erros de acento foram pouquíssimos e, por essa razão, não interfeririam nos resultados gerais, apesar de serem predominantemente iâmbicos. No entanto, o mesmo não é observado em DES, que apresenta uma predominância de SW assim como DEX quando o léxico particular está ausente, mas quando os dados são considerados no seu total passa a apresentar uma predominância de WS em Fx1.

No que se refere aos processos de apagamento, o modelo que mais sofreu esse tipo de processo favorecendo a produção monossilábica em DEX foi o WS, mas o mesmo não ocorreu em DES que apresentou mais apagamento em SW. O trissílabo WSW que, segundo GERKEN (1994), quando sofre apagamento de sílabas pode mostrar evidências a favor da tendência prosódica predominante, em DEX foi produzido, majoritariamente, como SW, enquanto que em DES houve tanto produção de SW (verbos) quanto de WS (nomes).

Observando a tendência iâmbica apontada nos resultados totais de DES, tudo parece indicar que o estudo que desconsidere todos os tipos de léxico não pode, assim, afirmar, categoricamente, uma tendência inicial. Por essa razão, acredita-se que o PB apresente uma tendência iâmbica inicial, embora aparente estatisticamente, tendência defendida pelos estudos observacionais (BONILHA, 2004; SANTOS, 2006, 2007; BAIA, 2006) que contemplam a produção lexical infantil na sua totalidade.

Assim, pode-se afirmar que os resultados de DES corroboram o que tem sido apontado pelos demais estudos observacionais, dentre eles o de Santos (2007), o qual merece destaque por esta pesquisa ter trilhado um caminho parecido com o dele na análise. Cabe ressaltar que como os dados contemplados por Santos (2007) estendem-se até a idade de 2 anos, compara-se os resultados da autora com o que foi observado em Fx1. Assim 
como foi observado nos dados desta pesquisa, Santos nota que há um aumento na quantidade de acentos finais quando as palavras familiares são computadas no total de dados (p. 37). No entanto, os resultados da autora diferem dos desta pesquisa no que se refere ao papel do léxico particular, pois nos seus dados de nomes sem léxico particular também houve predominância de iambos, enquanto que em DES sem esse tipo de léxico encontrou-se o predomínio de troqueus. Isso pode ocorrer pelo fato da autora ter considerado apenas dados de produções familiares, deixando de analisar dados de criações lexicais. Porém, essa mesma explicação não pode ser utilizada a respeito da diferença entre os resultados de Santos em relação aos verbos (sem léxico particular) que apontam uma predominância de monossílabos seguida por SW, enquanto que DES-verbos sem léxico particular apresenta o predomínio de iambos. Todavia, esse predomínio de monossílabos e troqueus observado pela autora pode ocorrer devido ao período analisado (1;3 - 2,0 anos), pois o analisado em DES e DEX é mais tardio (inicia aos 1;5 anos).

Cumpre voltar a uma decisão metodológica assumida no início desta tese, a saber a de utilizar dados de fala semi-espontânea. Uma possível crítica para este uso seria de que há alguns estudos que mostram um resultado diferente quando a imitação é considerada. Como foi esclarecido na metodologia de nossa pesquisa, somente DEX contou dados de fala semiespontânea e os resultados mostraram um padrão trocaico. Importante, esta mesma tendência foi observada também em DES, que só incluía dados de fala espontânea, isto é: ao analisar somente os nomes, sem SLP, tanto em DES (fala espontânea) quanto em DEX (fala espontânea e semi-espontânea) observou-se que eles apresentam uma tendência trocaica. Portanto, é possível concluir que o tipo de fala (espontânea vs não-espontânea) não influenciou nos resultados. 
Enfim, notou-se com a análise dos dados do PB que a metodologia influencia no que se refere ao design do método. Tal constatação pede uma revisão na literatura que defende uma tendência trocaica inicial (cf. ALLEN \& HAWKINS, 1980, GERKEN, 1994; FIKKERT, 1994, ADAM \& BAT-EL, 2007 entre outros), pois a maior parte dos estudos realiza um trabalho apenas atentando para nomes e se prende ao léxico comum. 


\section{CONCLUSÕES}

Os resultados obtidos por meio dos dois estudos realizados nesta pesquisa corroboram o que é afirmado pelo estudo experimental de Rapp (1994) e pelos estudos observacionais (SANTOS, 2001, 2007; BONILHA, 2004; BAIA, 2006). Dessa maneira, os resultados deste estudo apresentam a mesma discrepância de tendência prosódica inicial presente na comparação dos estudos que adotam diferentes métodos. No entanto, foi encontrada uma resposta a respeito do que ocasiona tal discrepância.

Notou-se que os iambos diminuem se o léxico particular e os verbos forem excluídos dos dados. Sem o léxico particular e verbos, há uma predominância de SW em DES e DEX, por isso a discrepância entre os estudos experimentais e naturalísticos ocorre. Dessa maneira, a diferença entre os resultados do estudo experimental e dos estudos observacionais está relacionada com a metodologia empregada e, particularmente, com o inventário lexical e classe gramatical considerados na análise.

Por fim, acredita-se que o estudo que desconsidere todos os tipos de produções infantis não pode afirmar, categoricamente, uma outra tendência inicial. Por essa razão, afirma-se que o PB apresenta uma tendência iâmbica inicial, tendência defendida pelos estudos naturalísticos (BAIA, 2006, SANTOS 2007) que lidam com a produção lexical infantil na sua totalidade, embora não se trate de uma tendência forte e seja apenas uma tendência aparente de acordo com os resultados estatísticos deste estudo. Além disso, por não haver um valor default do núcleo (SANTOS, 2007), iambos não deixam de coexistir com os troqueus. 


\section{BIBLIOGRAFIA}

ADAM, G. \& BAT-EL, O. "The trochaic is universal: evidence from hebrew" in Generative approaches to language acquisition, Barcelona, 2007.

AGOSTINHO, A. \& ARAÚJO, G. A. "Um estudo estatístico sobre as oxítonas no português" in Signótica vol. 19, n.2, 2007.

ALLEN, G.D. \& HAWKINS, S. "Phonological rhythm: definition and development" em G. Yeni-Konishian; J.F. Kavanagh \& C.A. Ferguson (eds) Child Phonology vol. 1: production 227-256 NY Academic Press, 1980.

ALLEN, G. D. "Some suprasegmental contours in French Two-Year-Old Children's speech" In Phonetica, Vol.40, No. 4, 269-292, 1983.

ARCHIBALD, J. "The acquisition of stress" J. Archibald (ed.) Phonological Acquisition and Phonological Theory, 81-109, 1995.

BAIA, M.F.A. Verificação da tendência trocaica na aquisição do português brasileiro como língua materna. Relatório FAPESP de IC, processo no 03/13139-5, 2006.

BISOL, L. "O acento e o pé métrico binário" In Cadernos de Estudos Lingüísticos, Campinas, (22): 69-80, jan./jun, 1992.

BOLOZKY, S. "Remarks on rhythmic stress in modern hebrew". Journal of Linguistics, 19, 275-289,1982.

BOLTON, T. “Rhythm”. American Journal of Psychology. 6: 145-238, 1894.

BONILHA, G. F. G. Aquisição Fonológica do português brasileiro: uma abordagem conexionista da Teoria da Otimalidade. Rio Grande do Sul: PUC, Dissertação de doutorado, 2004.

CHOMSKY, N. Aspects of the Theory of Syntax. Cambridge: MIT Press, 1965.

Reflections on language. Nova Iorque: Pantheon Books, 1975.

MIT Press, 1981.

Lectures on Government and Binding: The Pisa lectures. Cambridge:

Linguagem e mente: pensamentos atuais sobre antigos problemas.

Tradução de Lúcia Lobato, revisão de Mark Ridd. Brasilía: Ed. Universidade de Brasília, 1998.

CHOMSKY, N. \& HALLE, M. The sound pattern of English. Harper \& Row.New York, 1968.

CINTRA, G. "Distribuição de padrões acentuais no vocábulo em português" em Confluência vol. 5. n. 3 83-92 ed. Unesp Assis, 1997.

CLARK, E.V. First Language Acquisition United Kingdom: Cambrigde University Press, 2005.

CONSONI, F.O acento lexical como pista para o reconhecimento das palavras. Dissertação de mestrado FFLCH-USP, 2006.

CORREIA, S., COSTA, T. \& FREITAS, M.J. O pé no PE. Comunicação no $7^{\circ}$ ENAL, 2006.

COUTINHO, I. L. Gramática Histórica. Rio de Janeiro: Livraria Acadêmica, 1969. 
CRAIN, S. \& THORNTON, R. Investigations in Universal Grammar: A guide to experiments on the acquisition of syntax and semantics. The MIT Press: Cambridge, MA, 2000.

CRAIN, S.; WEXLER, K. "Methodology in the study of language acquisition: a modular approach" in Ritchie, W. and Bhatia, T. eds, Handbook of child language acquistion, p. 427-456, Academic Press, 1999.

DEMUTH, K. "Markedness and the development of Prosodic Structure" em Proceedings of the NELS, vol.25, 1995.

"The prosodic structure of early words" em J. Morgan \& K. Demuth (eds)

Signal to Syntax: Bootstrapping from Speech to Grammar in Early Acquisition, 171-184 Lawrence Erlbaum ed, 1996.

"The satus od feet in early acquisition" in $15^{\text {th }} \quad$ International Congress od

Phonetic Sciences (ICPhS). Universidad Autonima de Barcelona, p.151-154, 2003.

DEMUTH, K. \& JOHNSON, M. "Truncation to subminimal words in early French" in Canadian Journal of Linguistics. 48 (3/4): 211:241, 2003.

DRESHER, B.E. \& KAYE, J. D. "A computational learning model for metrical phonology" in Cognition, 34, p. 137 - 195, 1990.

ECHOLS, C. H. \& NEWPORT, E. L. "The role of stress and position in determining firt words". In Language Acquisition, no2: 189-220, 1992.

ELliOT, A. J. A linguagem da criança. Trad. de Vera Ribeiro. Rio de Janeiro: Zahar Editores, 1982.

FERGUSON, C. "Baby Talk in Six Languages." American Anthropologist. 66.6 -Part 2 (1964):102-114, 1964.

FERREIRA NETTO, W. Introdução à fonologia da língua portuguesa. São Paulo, Hedra, 2001.

FIKKERT, P. On the acquisition of prosodic structure. Phd. Dissertation, HIL dissertations 6, Leiden University. The Hague: Holland Academic Graphics, 1994.

FUDGE, E.C. Syllables. Journal of Linguistics 5:253-286, 1969.

"Words and feet" in J. Linguistics , 35, 273-296. Printed in the United Kingdom. Cambrigde University Press, 1999.

GERKEN, L. A. "A metrical template account of children's weak syllable omissions from multisyllabic words" em Journal of Child Language, vol.21 565-584, Cambridge University Press, 1994.

GLINERT, L. "The grammar of modern Hebrew". Cambrigde: Cambridge University Press, 1989.

GRIMM, A. "The prosodic pattern of words and phrases in the acqusitionof German" in $9^{\text {th }}$ Conference on Laboratory Phonology. Alemanha: Universidade Iiibinguen, 2004.

HALLE, M. \& VERNAUD, J-R. An essay on stress. Cambrigde, Mass.: MIT Press, 1987. HAYES, B. Metrical Stress Theory - Principles and Case Studies. UCLA, 1995.

HOCHBERG, J. G. "First steps in the acquisition of Spanish stress" em Journal of Child Language n. 15 273-292 Cambridge University Press, 1988a.

"Learning spanish stress: developmental and Theoretical

perspectives" in Language vol.64 n. 4 683-706 Linguistic Society of America Baltimore, MD, 1988b. 
HOGG, R. \& McCULLY, C.B. Metrical Phonology: a course book. Cambridge University Press, 1987.

JAKOBSON, R., FANT, G. \& HALLE, M. Preliminaries to Speech Analysis. Cambridge, MA: MIT Press, 1952.

JAKOBSON, R. Child Language Aphasia and Phonological Universals. $2^{\circ}$ edição. The Hague \& Paris, Mouton, 1972.

JAPIASSÚ, H. \& MARCONDES, D. Dicionário básico de filosofia. Rio de Janeiro: Editora Jorge Zahar, 1996.

KARMILOFF, K. \& KARMILOFF-SMITH, A.Pathways to language: from fetus to adolescent. Cambrigde: Havard University Press, 2001.

KATO, M. "Raízes não-finitas na criança e a construção do sujeito". Caderno de Estudos Lingüísticos, 29: 119 -136, 1996.

KEHOE,M. \& STOEL-GAMMON, C. "The acquisition of prosodic structure: An investigation of current accounts of children's prosodic development" IN Language, Volume 73, Number 1, 1997.

KEHOE, M. "Prosodic Pattern in Children's multisyllabic word productions" in Language, Speech and Hearing Services in Schools. Vol.32, 284-294, 2001.

KLEIN, H. B. " Learning to stress: a case study" IN Journal of Child Language, II, 375-390), 1984.

LEE, S. Morfologia e fonologia lexical do português do Brasil. Campinas: UNICAMP, 1995.

LEVIN, J. Estatística aplicada a ciências humanas. 2.ed. São Paulo; Harbra, 1985.

LlÉO, C. "Acquisition of Prosodic Word Structures in Spanish" IN $2^{\text {nd }}$ Lisbon Meeting on Language Acquisition with Special Reference to Romance Languages. 1-4 Junho, 2004.

LIBERMAN, M. \& PRINCE, A. On stress and linguistic rhythm”. L. In. 8: 249 - 336, 1977.

LIBERMAN, M. The intonational system of English, tese de doutorado, MIT, 1974.

LIBERMAN, M. \& PRINCE, A. "On stress and linguistic rhythm". Linguistic inquiry, n.8, 249-336, 1977.

MASSINI-CAGLIARI, G. "Cantigas de amigo: do ritmo poético ao lingüístico. Um estudo do percurso histórico da acentuação em português. Tese de Doutorado, UNICAMP, 1995.

"O conceito de pé como unidade rítmica: trajetória" in Estudos de prosódia, org. Scarpa, E. M, Campinas, SP: Editora da UNICAMP, 1999.

MATTOSO CÂMARA JR., J. História e Estrutura da Língua Portuguesa. Rio de Janeiro: Padrão, 1975.

MAcWHINNEY, B. The CHILDES project - Computational tools for analyzing talk. Hillsdale, NJ: Lawrence Erlbaum Associates, 1991.

MEISEL,J. "Parâmetros na aquisição" In FLETCHER, P. \& McWHINNEY, B. (orgs). Compêndio da linguagem da criança. Porto Alegre: Artes Médicas, 1997.

NESPOR, M. \& I. VOGEL Prosodic Phonology, Foris Publications, Dordrecht, Holland, 1986.

NIVETE, J. Princípios da gramática gerativa. São Paulo: Pioneira, 1975. 
PEREIRA, I. "Panorama das abordagens lingüísticas das questões prosódicas" IN Estudos em Prosódia. Edições Colibri, 1992.

"Acento latino e acento em português: que parentesco?" in $O$ acento em português: abordagens fonológicas, Gabriel Antunes de Araújo- org, São Paulo: Parábola Editorial, 2007.

PRIETO, P. "Early prosodic word acquisition in Catalan" in Second Lisbon Meeting on Language Acquisition with special reference to Romance Languages. Lisboa (a ser publicado), 2005.

RAPP, C. "O grau de difusão do processo de elisão das sílabas não acentuadas na aquisição do português como língua materna" in Estudos Lingüísticos e Literários, nº 12, Salvador, UFBA, 1991.

A Elisão de Sílabas Fracas nos Estágios Iniciais da Aquisiçãoda Fonologia do Português, dissertação de mestrado, UFB, 1994.

“A elisão das sílabas não acentuadas na aquisição do português como língua materna”. Estudos Lingüísticos e Literários, n¹7, julho, 1995.

ROCA, I. "Stress and syllables in Spanish". In CAMPOS, A. \& MARTÍNEL-GIL, F. Current studies in Spanish Linguistics, 1991.

"Stress in the Romance Languages" In van der Hulst, H. (ed.). Word Prosodic Systems in the Languages of Europe. Berlin: Mouton de Gruyter, 659-811, 1999.

SANTOS, R.S. A aquisição do acento primário no Português Brasileiro, dissertação de doutorado UNICAMP, 2001.

"A aquisição da estrutura silábica e sua relação com o acento primário em Português Brasileiro” In Sínteses Revista dos Cursos de Pós-Graduação, vol.7, p.309-323, 2002.

Word Stress Acquisition: A Comparison between Brazilian Portuguese and Dutch. Proceedings 30, BU, 2006.

A aquisição prosódica do português brasileiro de 1 a 3 anos: padrões de palavra e processos de sândi externo. São Paulo: Universidade de São Paulo. tese de livre docência, 2007.

SANTOS \& FIKKERT, P. "The Acquisition of word stress: bottom-up or top-down: a cross-linguistic perspective".In $V$ Workshop on Phonological Acquisition. Holanda: Rodbod Universiteit, 2005.

SCARPA, E. M. - The Development of Intonation and Dialogue Processes in two Brazilian Children. Tese de doutorado, University of London, 1984.

"Learning External Sandhi. Evidence For A Top-Down Hypothesis Of Prosodic Acquisition". In: GALA'97 Conference on Language Representation and Processing, 1997.

Estudos de Prosódia, Campinas: Editora UNICAMP, 1999.

SECCO, G. Criações lexicais em uma criança de 20 meses de idade. Dissertação de Mestrado. Florianópolis: UFSC, 1994.

STOEL - GAMMON, C. "Baby talk in Brazilian Portuguese" IN Revista Brasileira de Lingüistica, vol. 3, nº1, 22-26, 1976.

TAELMAN, H. Syllable omissions and additions in Dutch child language ininquiry into the function of rhythm and the link with innate grammar. Tese deDoutorado. Holanda: Universidade Antwerpen, 2004. 
TAELMAN, H., \& GILLIS, S. "Variation in children's early production of multisyllabic words: The case of truncations". In: S. Kern (Ed.), Early lexicon acquisition: normal and pathological development, Lyon: Université Lumi\&egravere Lyon 2, 2001.

VIHMAN, M. M; DEPAOLIS, R. A.; DAVIS, B. L. "Is there a 'Trochaic Bias" in Early Word Learning? Evidence from infant production in English and French" in Child Development, volume 69, n. 4, pg 935-949, 1998.

WIJNEN. F., KRIKHAAR E. \& DEN OS E. "The (non)realization of unstressed elements in children's utterances: evidence for a rhythmic constraint". IN Journal of Child Language, 21, 59-83, 1994.

WOODROW, H. "A quantitive study of rythm: the effect of variations in intensity, rate and duration". Archives of Psychology. 14: 1-66, 1909. 


\section{ANEXOS}

9.1 Anexo 1: desenhos utilizados em DEX
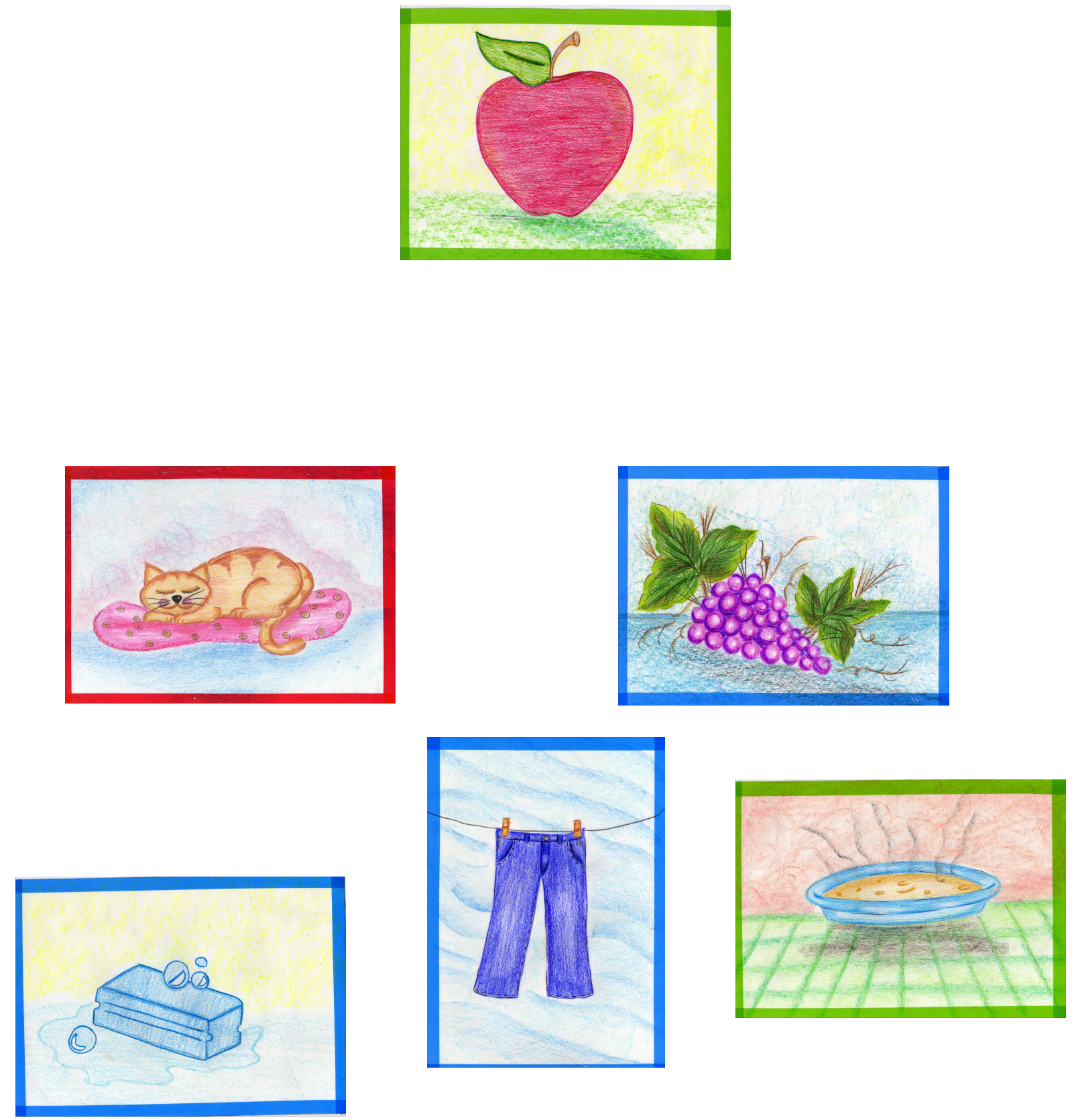

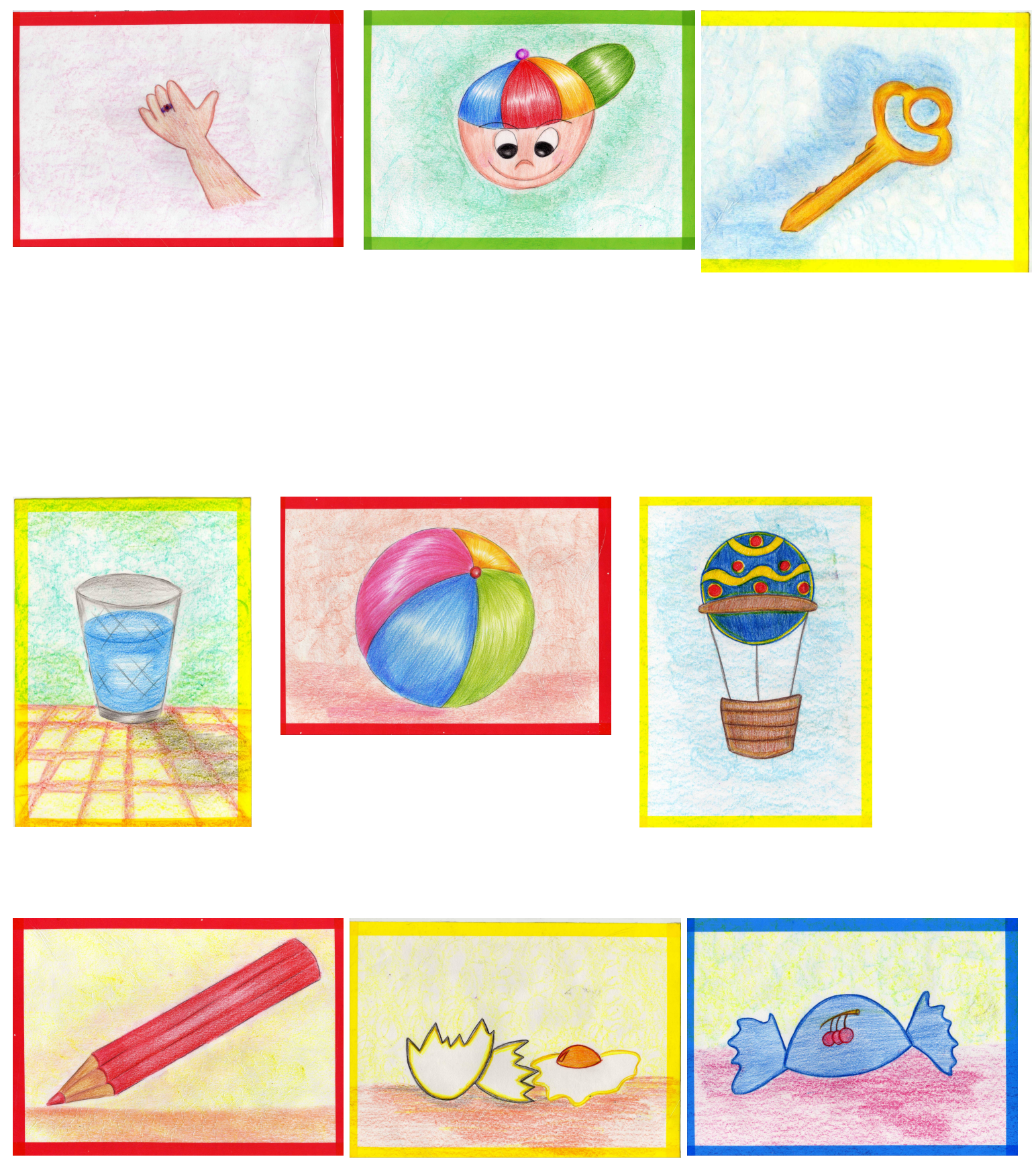

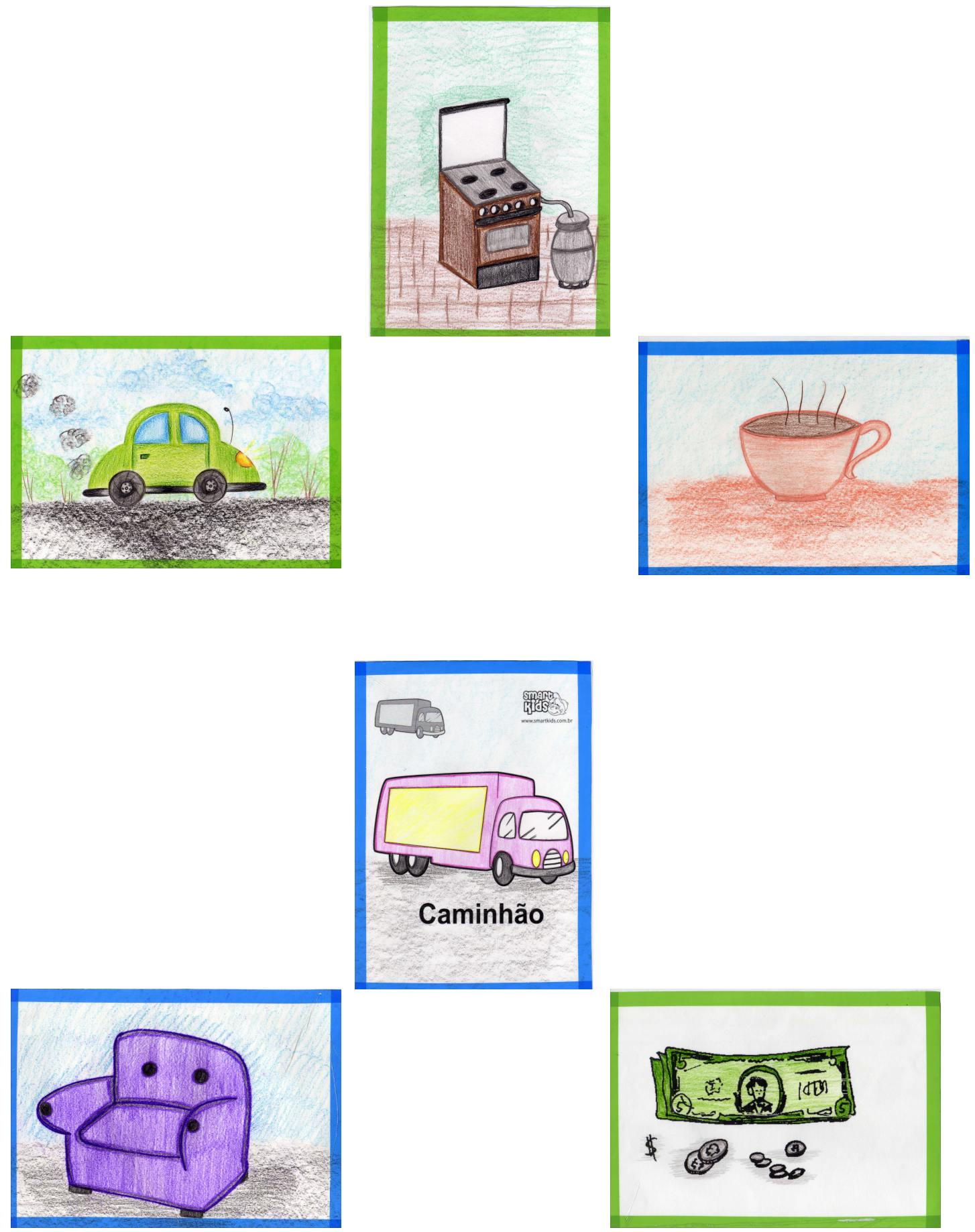

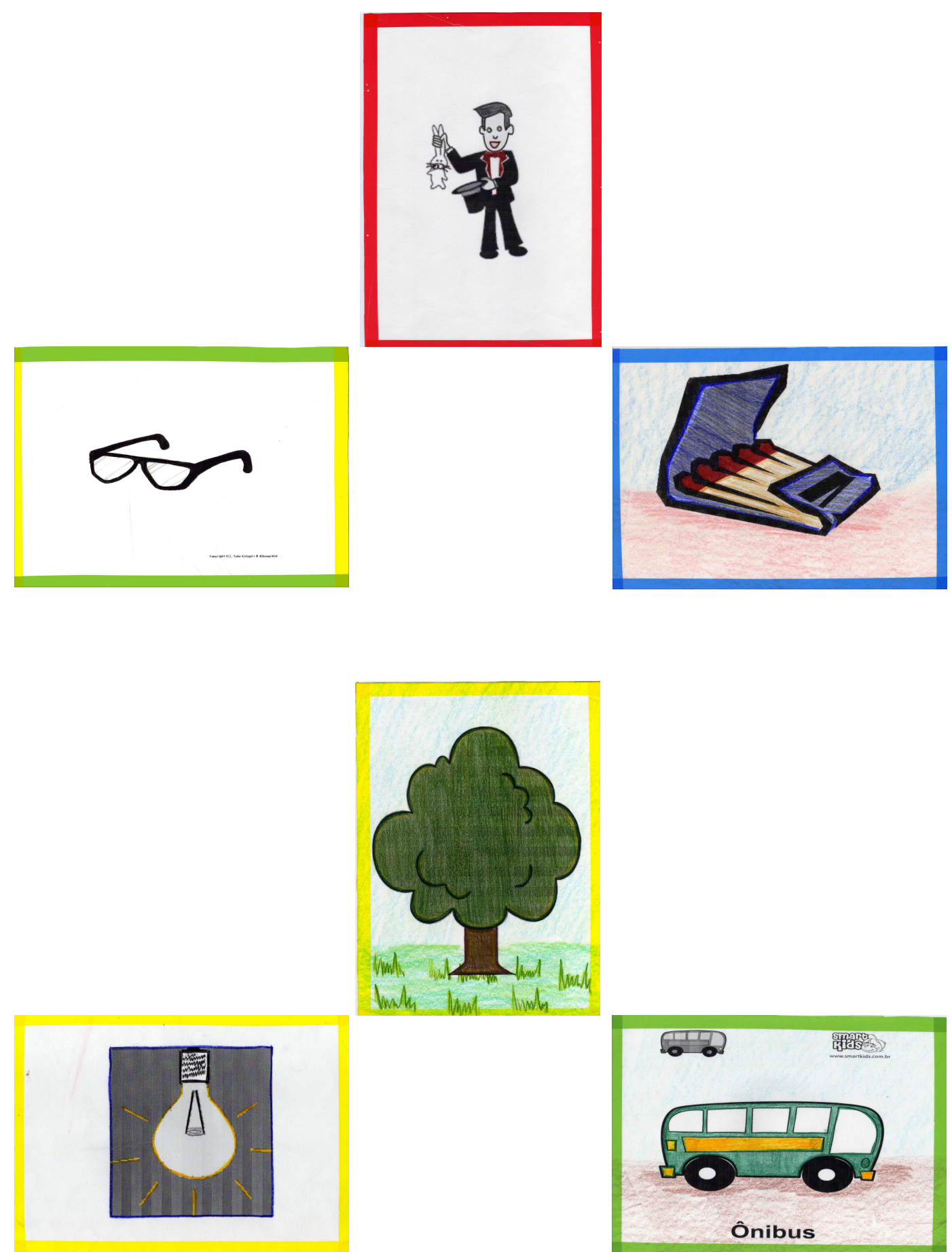

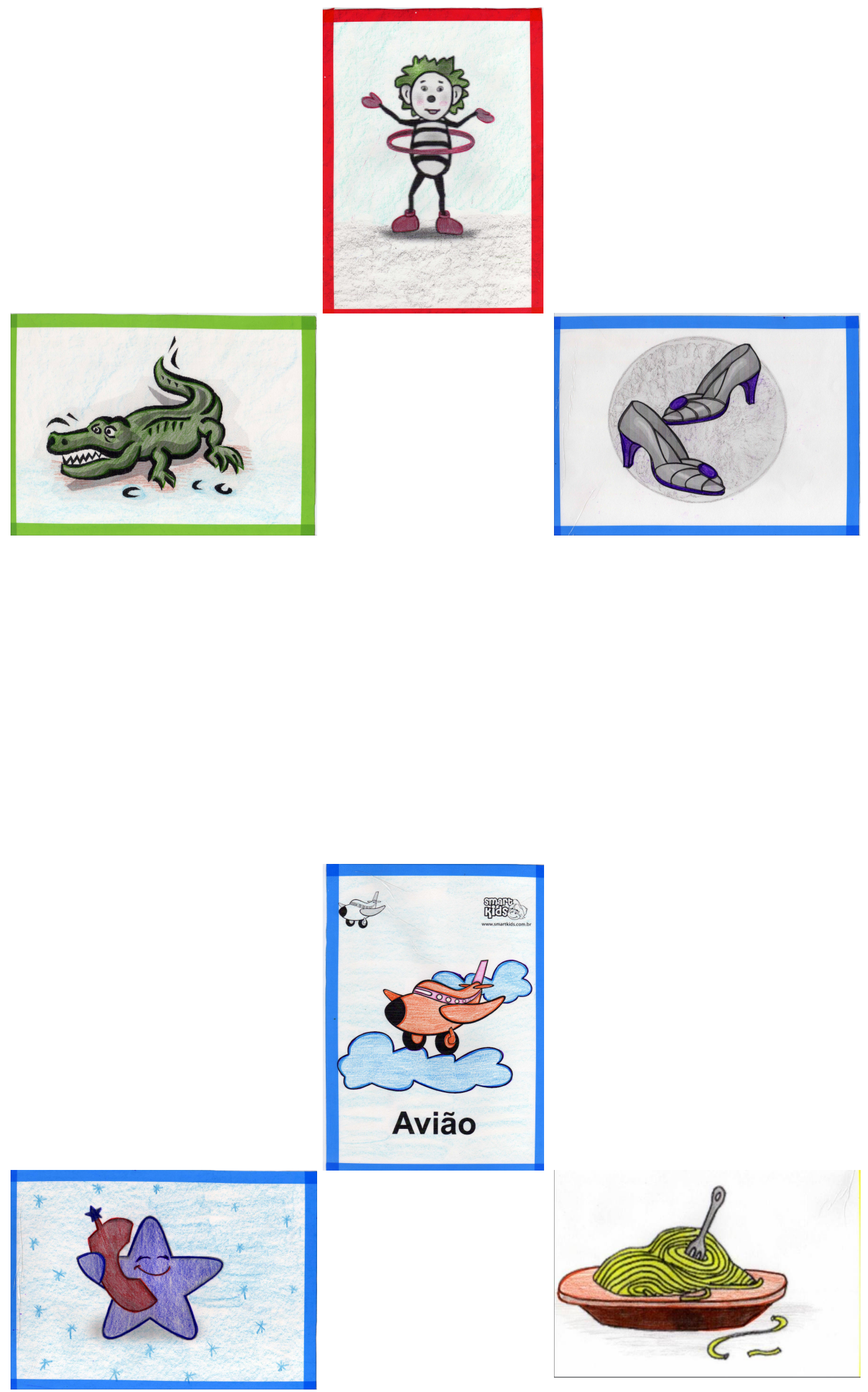

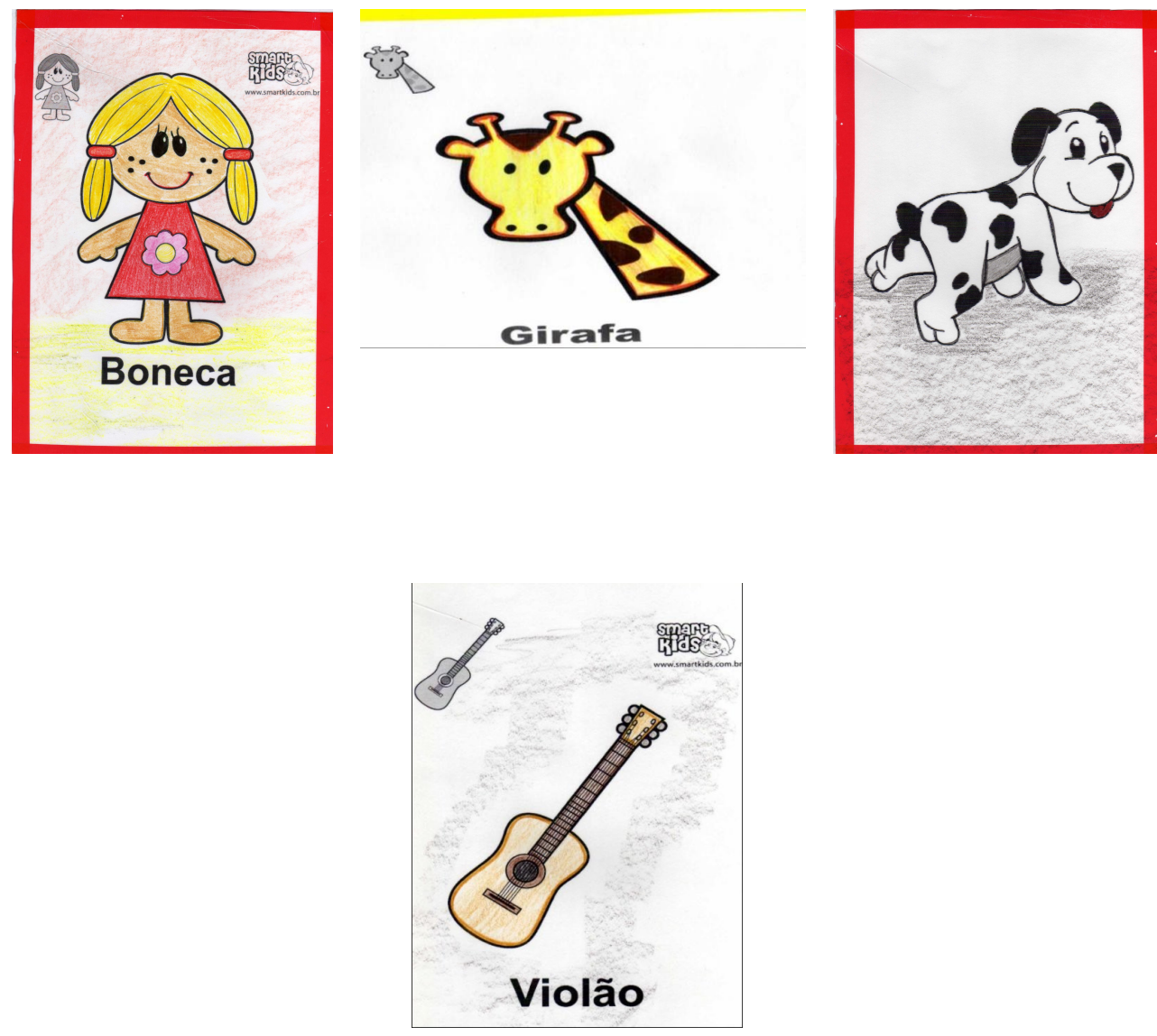

\subsection{Anexo 2: dados experimentais (DEX)}

SW

\begin{tabular}{|c|c|c|c|c|c|c|c|c|c|c|}
\hline Criança/ldade & carro & lápis & bola & copo & prato & ovo & chave & calça & uva & gato \\
\hline 1 P. C./ 1;5 & [bi.'bi] & ['e.tr] & --- & {$[\mathrm{k} 0]$} & [pa] & [o] & --- & [ka] & {$[\mathrm{u}]$} & --- \\
\hline 2 L. G. $/ 1 ; 5$ & {$[\mathrm{ka}]$} & ['a.pI ] & [bo] & {$[\mathrm{ko}]$} & [pa] & [o.'u] & ['ta.I ] & [ka] & ['u.e] & ['ga.u] \\
\hline 3 T. S./1;6 & ['ka.v] & ['a.pr] & ['bo.e] & ['ko.pu] & ['pa.tu] & [o.'u] & ['ka.vi] & [kaw] & [a.'a] & ['ga.tu] \\
\hline 4 P. M. / 1;7 & {$[\mathrm{ka}]$} & [pi] & [bo.'bo] & [ko] & ["pa.tu] & [o] & [i] & [kaw] & {$[\mathrm{u}]$} & [ka.'ka] \\
\hline 5 E. S./1;8 & ['ka.v] & ['a.pI ] & ['bo.le] & ['ko.pv] & ['pa.tv] & ['o.bu] & ['ta.bI ] & [ka.'ka] & ['u.be] & ['ga.tu] \\
\hline 6 J. P. $/ 1 ; 8$ & ['ka.u] & ['a.pI ] & [bo] & [ko.'pu] & ['pa.tv] & ['do.bu] & ['ba.vI ] & [ka.'ku] & [u.'va] & [ga.'ku] \\
\hline 8 G. A./1;8 & ['ka.v] & ['a.pI ] & [bo] & ['bo.t5I] & ['pa.tv] & [o.'u] & ['ta.vI ] & [kaj] & [va] & ['ga.tv] \\
\hline 8 L. G./1;9 & ['ka.v] & ['a.pIs] & ['bo.le] & ['ko.pu] & ['pa.tv] & ['o.bu] & ['ta.bI ] & ['ka.te] & ['u.be] & ['ga.tu] \\
\hline 9 A. F. $1 ; 10$ & ['ka.v] & ['a.pI s] & ['bo.le] & ['ko.pu] & ['pa.tv] & ['o.bu] & ['ba.vi ] & ['ka.se] & ['u.ve] & ['ga.tv] \\
\hline 10 J. H./1;11 & ['ka.v] & [pi] & ['bo.le] & ['ko.pv] & ['pa.tu] & ['o.bu] & ['ta.vI ] & ['ka.se] & ['u.be] & ['ga.tv] \\
\hline 11 G. V./2;0 & ['ka.v] & ['a.pis] & [o.'ta] & ['ka.pv] & ['pa.tv] & [o] & ['ta.ve] & ['ko.se] & ['u.ve] & ['ga.tv] \\
\hline
\end{tabular}




\begin{tabular}{|c|c|c|c|c|c|c|c|c|c|c|}
\hline 12 А. J. $/ 2 ; 0$ & ['ka.xv] & ['a.pis] & ['bo.le] & ['ko.pv] & ['pa.tv] & ['o.vu] & ['ta.vi ] & ['kaw.se] & ['u.ve] & ['ga.tv] \\
\hline $13 \mathrm{~K} . \mathrm{W} . / 2 ; 0$ & ['ka.v] & ['pa.pI ] & ['bo.le] & ['ko.pu] & ['pa.tv] & [o.'u] & ['ta.vI ] & ['ka.se] & ['u.p] & ['ga.tv] \\
\hline 14 J. V./2;1 & [ka:] & ['la.pr ] & [di.'ko] & [go] & ['pa.tu] & ['o.bu] & [na.'na] & [ka] & {$[\mathrm{ta}]$} & ['ba.tv] \\
\hline 15 I. S. $/ 2 ; 1$ & ['ka.v] & ['la.pI ] & ['bo.le] & ['ko.pu] & ['ga.tv] & ['o.ve] & ['ta.t $\left.\int \mathrm{I}\right]$ & ['ka.se] & [va] & ['ga.tSv] \\
\hline 16 C. M./2;1 & [ka.'kaw] & ['la.pI] & [a.'bo] & ['ko.pv] & [a.'pa.tu] & [o.'va] & [a.ta.'ve] & ['ka.se] & [va] & ['ka.tv] \\
\hline 17 T. S. $/ 2 ; 1$ & ['ka.v] & ['la.pr ] & ['bo.le] & ['ko.pv] & ['pa.tv] & ['o.vU] & ['ta.vI ] & ['ka.se] & ['u.ve] & ['ga.tv] \\
\hline 18 D.T. $/ 2 ; 1$ & ['ko.v] & [pi] & ['bo.e]] & [ko] & ["pa.tv] & [0] & ['sa.vI] & ['ta.tI ] & [va] & [ga] \\
\hline 19 A. I. $/ 2 ; 2$ & ['ka.v] & ['la.pI ] & ['bo.le] & ['ko.pu] & ['pa.tv] & ['o.vu] & ['sa.vI ] & ['kaw.se] & ['u.ve] & ['ga.tv] \\
\hline 20 M. L. $/ 2 ; 2$ & ['ka.] & ['la.pi s] & ['bo.le] & ['ko.pu] & ['pa.tv] & ['o.vu] & ['sa.vI] & ['ka.se] & ['u.ve] & ['ga.tv] \\
\hline 21 J. C./2;3 & ['ka.v] & ['la.pr ] & [bo.'la] & ['po.pv] & ['pa.tv] & ['ow.vv] & ['fa.vI ] & ['ka.je] & [a.'u.ve] & ['ga.to] \\
\hline 22 G. R./2;4 & [ka.'u] & ['la.pI ] & [bo.'la] & ['ko.pv] & ['pa.tv] & ['o.vu] & ['sa.vI ] & ['kaw.se] & ['u.ve] & ['ga.tu] \\
\hline 23 P. S. $/ 2 ; 5$ & [ka.'u] & ['la.pI s] & ['bo.le] & ['ko.pv] & ['pa.tv] & ['o.vu] & ['Sa.vi] & ['ka.se] & ['u.ve] & ['ga.tu] \\
\hline 24 E. P./ 2;5 & [ka.'u] & ['la.pi s] & ['bo.le] & ['ko.pv] & ['pa.tv] & ['o.vu] & ['Sa.vI] & ['ka.se] & ['u.ve] & ['ga.tv] \\
\hline 25 G.F. $/ 2 ; 6$ & ['ka.v] & ['la.pI ] & ['bo.le] & ['ko.pv] & ['pa.tv] & ['o.vu] & ['sa.vI ] & ['kaw.se] & ['u.ve] & ['ga.tv] \\
\hline 26 B. F. $/ 2 ; 6$ & ['ka.v] & ['la.pI ] & ['bo.le] & ['ko.pv] & ['pa.tv] & ['o.vU] & ['sa.vI ] & ['ka.se] & ['u.ve] & ['ga.tv] \\
\hline 27 V. S./2;7 & ["ka.v] & ["la.pi s] & ['bo.le] & ['ko.pv] & ['pa.tv] & ['o.vu] & ['sa.vI ] & ['ka.se] & ['u.ve] & ['ga.tv] \\
\hline 28 J. O./2;7 & ['ka.v] & ["la.pi s] & ['bo.le] & ['ko.pv] & ['pa.tv] & ['o.bu] & ['ta.vI ] & ['kaw.se] & ['u.ve] & ['ga.tv] \\
\hline 29 G. S./2;7 & ['ka.v] & ['la.pe] & ['bo.e] & ['po.kv] & ['pa.tv] & ['o.vu] & ['sa.vI ] & ['ka.se] & ['u.ve] & ['ga.tv] \\
\hline 30 V.S. $/ 2 ; 7$ & ['ka.xv] & ['la.pi s] & ['bo.le] & ['to.pu] & ['pa.tv] & ['o.vu] & ['Sa.vI ] & ['kaw.se] & ['u.ve] & ['ga.tv] \\
\hline 31 D. C. $/ 2 ; 7$ & ['ka.xu] & ['la.pi s] & ['bo.le] & ['to.pu] & ['pa.tv] & ['o.vu] & ['Sa.vI ] & ['kaw.se] & ['u.ve] & ['ga.tv] \\
\hline 32.J. V. P. $/ 2 ; 7$ & ['ka.v] & ['la.pi S] & ['bo.le] & ['ko.pv] & ['pa.tu] & ['o.vu] & ['Sa.vI ] & ['kaw.se] & ['u.ve] & ['ga.tu] \\
\hline 33 C. A. $/ 2 ; 8$ & ['ka.xu] & ['la.pI ] & ['bo.le] & ['ko.pu] & ['pa.tv] & ['o.vu] & ['sa.vI ] & [a'kaw.se] & ['u.ve] & ['ga.tv] \\
\hline 34 M. S. $/ 2 ; 8$ & ['ka.xu] & ['la.pi s] & ['bo.le] & ['ko.pv] & ['pa.tv] & ['o.vU] & ['sa.vI ] & ['kaw.se] & ['u.ve] & ['ga.tv] \\
\hline 35 O. G. $/ 2 ; 9$ & ['ka.v] & ['la.pI ] & ['bo.le] & ['ko.pu] & ['pa.tu] & ['o.vu] & ['sa.vI ] & ['kaw.e] & ['u.ve] & ['ga.tu] \\
\hline 36 A. L.D.;2;9 & ['ka.xu] & ['la.pI ] & ['bo.le] & ['ko.pv] & ['pa.tu] & ['o.vu] & ['Sa.VI ] & ['ka.se] & ['u.ve] & ['ga.tu] \\
\hline 37 R. S. $/ 2 ; 10$ & ['ka.v] & ['la.pI ] & ['bo.le] & ['ko.pv] & ['pa.tv] & ['o.vu] & ['Sa.vI ] & ['kaw.se] & ['u.ve] & ['ga.tv] \\
\hline 38 A. B. V./2;10 & ['ka.xv] & ["la.pi s] & ['bo.le] & ['ko.pv] & ['pra.tv] & ['o.vU] & ['Sa.vI ] & ['kaw.se] & ['u.ve] & ['ga.tv] \\
\hline 39 P. S./ 2;11 & ['ka.xv] & ['la.pi s] & ['bo.le] & ['ko.pv] & ['pa.tv] & ['o.vu] & ['Sa.vI ] & ['kaw.se] & ['u.ve] & ['ga.tv] \\
\hline 40 P.H./2;11 & ['ka.xv] & ["la.pi s] & ['bo.le] & ['ko.pv] & ['pa.tv] & ['o.vU] & ['Sa.vI ] & ['kaw.se] & ['u.ve] & ['ga.tv] \\
\hline 41 J. S. $/ 3 ; 0$ & ['ka.xv] & ["la.pi s] & ['bo.le] & ['ko.pv] & ['pa.tv] & ['o.vu] & ['Sa.vI ] & ['kaw.se] & ['u.ve] & ['ga.tv] \\
\hline 42 J. R. / 3;0 & ['ka.u] & ['la.pis] & ['bo.le] & ['ko.pu] & ['pa.tv] & ['o.vu] & ['Sa.vI ] & ['kaw.ss] & ['u.ve] & ['ga.tv] \\
\hline
\end{tabular}

\section{WS}

\begin{tabular}{|c|c|c|c|c|c|c|c|c|c|c|}
\hline Criança/Idade & fogão & boné & café & sofá & maçã & anel & bombom & balão & sabão & varal \\
\hline 1 P. C./ $1 ; 5$ & --- & {$[\varepsilon]$} & {$\left[f_{\varepsilon}\right]$} & [fa] & --- & {$[\mathrm{n} \varepsilon]$} & [bõ] & [ãw] & [bãw] & --- \\
\hline 2 L. G. $/ 1 ; 5$ & {$[\tilde{a}]$} & --- & [ka.' $\varepsilon]$ & [o.'a] & {$[\widetilde{a}]$} & {$[\mathrm{n} \varepsilon]$} & [bo.'bo] & [ãw] & [ba] & [aw] \\
\hline 3 T. S./1;6 & [go] & {$[\mathrm{n} \varepsilon]$} & {$[\mathrm{f} \varepsilon]$} & {$[\mathrm{fa}]$} & [bã] & [n\&w] & [bõ.'bõ] & [a.'la] & [ta.'bãw] & [baw] \\
\hline 4 P. M. / 1;7 & [gãw] & {$[\varepsilon]$} & {$[\mathrm{f} \varepsilon]$} & [o.'pa] & [bã] & {$[\mathrm{n} \varepsilon]$} & [bõ.'bõ] & [ãw] & [bãw] & [i.'aw] \\
\hline 5 E. S. $/ 1 ; 8$ & [gãw] & [nE] & [ka.'f $\varepsilon]$ & [so.'pa] & [ma.'sã] & [new] & [bõ.'bõ] & [ba.'ãw] & [bãw] & [baw] \\
\hline 6 J. P./1;8 & [ba] & [nE] & {$[\mathrm{b} \varepsilon]$} & [ba] & [bã] & ['nع] & [bõ.'bõ] & [ba.'bãw] & [ta.'bãw] & [va] \\
\hline 8 G. A. $/ 1 ; 8$ & [gãw] & {$[\mathrm{n} \varepsilon]$} & [ka.'f $f$ ] & [to.'fa] & [sã] & [n\&w] & [bõ.'bõ] & [bãw] & [bãw] & [aw] \\
\hline 8 L. G. $/ 1 ; 9$ & [gãw] & [bo.' $\mathrm{Ew}]$ & {$[\mathrm{f} \varepsilon]$} & [so.'fa] & [ma.'tã] & [new] & [mõ.'mõ] & [ba.'ãw] & [sa.'bãw] & [va.'vaw] \\
\hline 9 A. F. $1 ; 10$ & [gãw] & [bo.'nc] & [ka.'fe] & [to.'fa] & [sã] & {$[n \varepsilon w]$} & [bõ.'bõ] & [bãw] & [sa.'bãw] & [ba.'aw] \\
\hline 10 J. H./1;11 & [fo.'gãw] & [bo.'nc] & [ka.'fe] & [fa] & [ma.'sã] & [n\&w] & [bõ] & [ba.'ãw] & [sa.'bãw] & [ba.'aw] \\
\hline 11 G. V./2;0 & [fo.'kãw] & {$[\mathrm{n} \varepsilon]$} & [ka.'fe] & [to.'fa] & [ma.'sã] & [a.'ncw] & [bõ.'bo] & [ba.'ãw] & [bãw] & [va.'law] \\
\hline 12 A. J./2;0 & [fo.'gãw] & [bo.'ne] & [ka.'f $f$ ] & [so.'fa] & [ma.'sãw] & {$[\mathrm{n} \varepsilon \mathrm{w}]$} & [bo.'bãw] & [ba.'lãw] & [sa.'pãw] & [ba.'raw] \\
\hline
\end{tabular}




\begin{tabular}{|c|c|c|c|c|c|c|c|c|c|c|}
\hline $13 \mathrm{~K} . \mathrm{W} . / 2 ; 0$ & [gãw] & {$[\mathrm{n} \varepsilon]$} & {$[\mathrm{f} \varepsilon]$} & [fa] & [sã] & {$[\mathrm{n \varepsilon w]}$} & [bõ] & [ba] & [bãw] & [aw] \\
\hline 14 J. V./2;1 & $\overline{\text { [gãw] }}$ & [bo] & {$[\varepsilon]$} & [ta] & {$[\tilde{a}]$} & [a.'ह] & [bõ] & [bo] & $\begin{array}{l}\text { [gãw] } \\
\end{array}$ & [aw] \\
\hline 15 I. S./2;1 & [gãw] & {$[\mathrm{n} \varepsilon]$} & {$[f \varepsilon]$} & ['pa.ke] & [gã] & {$[\mathrm{n \varepsilon w}]$} & [bõ.'bõ] & [ãw] & [bãw] & [aw] \\
\hline 16 C. M./2;1 & [o.'kãw] & [ba.'ne] & [a.ka.'fc] & [a.ka.'fa] & [ba.'sã] & [pa.'da] & [bo.'bo] & [ba.'ãw] & [bãw] & [aw] \\
\hline 17 T. S. $/ 2 ; 1$ & [fo.'kãw] & [bo.'nc] & {$[\mathrm{f} \varepsilon]$} & [to.'fa] & [ma.'sã] & [nEw] & [bõ.'bõ] & [ba.'ãw] & [sa.'bãw] & [va] \\
\hline 18 D.T./2;1 & [go] & {$[\varepsilon]$} & {$[\varepsilon]$} & [pa] & [sã] & {$[\mathrm{n} \varepsilon]$} & [bõ.'bõ] & [bã] & [ãw] & [ba] \\
\hline 19 A. I. $/ 2 ; 2$ & [fo.'gãw] & [bo.'nc] & [ka.'fe] & [so.'fa] & [ma.'sã] & [nعw] & [bõ.'bõ] & [ba.'lãw] & [sa.'bãw] & [va.'law] \\
\hline 20 M. L. $/ 2 ; 2$ & [gãw] & [bo.'ncw] & {$[\mathrm{f} \varepsilon]$} & [so.'fa] & [mã.'sã] & [a.'ncw] & [bõ.'bõ] & [ba.'lãw] & [sa.'bõ] & [va.'raw] \\
\hline 21 J. C. $/ 2 ; 3$ & [gãw] & [bo.'sw] & {$[\mathrm{f} \varepsilon]$} & [fa] & [sã] & [nعw] & [bõ.'bõ] & [ba.'jãw] & [bãw] & [ba.'law] \\
\hline 22 G. R./2;4 & [fu.'gãw] & [bo.'nc] & {$[f \varepsilon]$} & [so.'fa] & [sã] & [new] & [bõ.'bõ] & [ba.'lãw] & [sa.'aw] & ['law] \\
\hline 23 P. S. $/ 2 ; 5$ & [fo.'gãw] & [bo.'ne] & [ka.'fe] & [so.'fa] & [mã.'sã] & [a.'ncw] & [bõ.'bõ] & [ba.'lãw] & [sa.'bãw] & [va.'raw] \\
\hline 24 E. P./ 2;5 & [fo.'gãw] & [bo.'nc] & [ka.'fe] & [so.'fa] & [sã] & [a.'ncw] & [bõ.'bõ] & [ba.'lãw] & [sa.'bãw] & ['raw] \\
\hline 25 G.F./2;6 & [fo.'gãw] & [bo.'nc] & [ka.'fe] & [so.'fa] & [ma.'sã] & {$[\mathrm{n} \varepsilon \mathrm{w}]$} & [bõ.'bõ] & [ba.'lãw] & [sa.'bãw] & [va.'law] \\
\hline 26 B. F. $/ 2 ; 6$ & [gãw] & [bo.'nc] & [ka.'fe] & [so.'fa] & [sã] & [n\&w] & [bõ.'bõ] & [ba.'lãw] & [sa.'bãw] & [va.'law] \\
\hline 27 V. S. $/ 2 ; 7$ & [fo.'kãw] & [bo.'nc] & [ka.'ff] & [so.'fa] & [ma.'sã] & [new] & [bõ.'bõ] & [ba.'lãw] & [sa.'bãw] & [va.'law] \\
\hline 28 J. O./2;7 & [fo.'gãw] & [bo.'nc] & {$[\mathrm{f} \varepsilon]$} & [so.'fa] & [a.ma.'sã] & [a.'ncw] & [bõ.'bõ] & [ba.'lãw] & [sa.'bãw] & [va.'law] \\
\hline 29 G. S./2;7 & [gãw] & [bo.'nc] & [ka.'fe] & [so.'fa] & [mã] & {$[\mathrm{n \varepsilon w}]$} & [bo.'nãw] & [bãw] & [ta.'bãw] & [aw] \\
\hline 30 V.S. $/ 2 ; 7$ & [fu.'dãw] & [bo.'nc] & [ka.'fe] & [so.'fa] & [ma.'sã] & [a.'ncw] & [bõ.'bõ] & [ba.'lãw] & [sa.'bãw] & [va.'law] \\
\hline 31 D. C. $/ 2 ; 7$ & [fo.'gãw] & [mo.'nc] & [ka.'f $f]$ & [so.'fa] & [ma.'sã] & [a.'ncw] & [bõ.'bõ] & [ba.'lãw] & [sa.'bãw] & [va.'raw] \\
\hline 32.J. V. P./2;7 & [fo.'gãw] & [bo.'ne] & [ka.'fe] & [so.'fa] & [ma.'ã] & [a.'new] & [bõ.'bõ] & [ba.'lãw] & [sa.'bãw] & [va.'law] \\
\hline 33 C. A. $/ 2 ; 8$ & [fo.'gãw] & [bo.'ne] & [ka.'fe] & [so.'fa] & [ma.'sã] & [a.'ncw] & [bõ.'bõ] & [ba.'lãw] & [sa.'pãw] & [va.'raw] \\
\hline 34 M. S. $/ 2 ; 8$ & [fo.'gãw] & [bo.'nc] & [ka.'f $f$ ] & [so.'fa] & [ma.'sã] & [a.'ncw] & [bõ.'bõ] & [ba.'lãw] & [sa.'bãw] & [va.'raw] \\
\hline 35 O. G./2;9 & [fo.'gãw] & [bə.'ne] & [ka.'fe] & [so.fa.'fa] & [ma.'sã] & [a.'ncw] & [bõ.'bõ] & [ba.'lãw] & [sa.'bãw] & [va.'law] \\
\hline 36 A. L.D.;2;9 & [fo.'gãw] & [bo.'nc] & [ka.'fe] & [so.'fa] & [ma.'sã] & [a.'ncw] & [bõ.'bõ] & [ba.'lãw] & [sa.'bãw] & [va.'law] \\
\hline 37 R. S./2;10 & [fo.'gãw] & [bo.'nc] & [ka.'fe] & [so.'fa] & [ma.'sã] & [a.'ncw] & [bõ.'bõ] & [ba.'lãw] & [sa.'bãw] & [va.'raw] \\
\hline 38 A. B. V./2;10 & [fo.'gãw] & [bo.'ne] & [ka.'fe] & [so.'fa] & [ma.'sã] & [n\&w] & [bõ.'bõ] & [ba.'lãw] & [sa.'bãw] & [va.'jaw] \\
\hline 39 P. S./ 2;11 & [fo.'gãw] & [bo.'nc] & [ka.'fe] & [so.'fa] & [ma.'sã] & {$[\mathrm{n} \varepsilon \mathrm{w}]$} & [bõ.'bõ] & [ba.'lãw] & [sa.'bãw] & [va.'raw] \\
\hline 40 P.H./2;11 & [fo.'gãw] & [bo.'nc] & [ka.'fe] & [so.'fa] & [ma.'sã] & [a.'ncw] & [bõ.'bõ] & [ba.'lãw] & [sa.'bãw] & [va.'raw] \\
\hline 41 J. S./3;0 & [fo.'gãw] & [bo.'nc] & [ka.'fe] & [so.'fa] & [ma.'sã] & [a.'ncw] & [bõ.'bõ] & [ba.'lãw] & [sa.'bãw] & [va.'raw] \\
\hline 42 J. R. / 3;0 & [fo.'gãw] & [bo.'nc] & [ka.'fe] & [so.'fa] & [ma.'sã] & [a.'ncw] & [bõ.'bõ] & [ba.'lãw] & [sa.'bãw] & [va.'raw] \\
\hline
\end{tabular}

\section{SWW}

\begin{tabular}{|c|c|c|c|c|c|c|}
\hline Criança/ldade & lâmpada & árvore & óculos & fósforo & ônibus & mágico \\
\hline 1 P. C./ $1 ; 5$ & [ã] & --- & ['o] & ['fo] & [õ] & --- \\
\hline 2 L. G./1;5 & [ã] & --- & ['o] & ['fo] & [õ] & --- \\
\hline 3 T. S./1;6 & ['ã.pr] & ['a.bI] & ['o.kv] & --- & ['õ.bu] & ['ma.gu] \\
\hline 4 Р. М. / 1;7 & --- & ['a.br] & ['o] & ['fo.v] & [õ] & [ma] \\
\hline 5 E. S. $/ 1 ; 8$ & ['ã.pe] & --- & ['o.fi.õ] & ['to.tr] & ['õ.br] & ['ma.ku] \\
\hline 6 J. P./1;8 & ['ã.pe] & ['a.vI] & ['o.ku] & ['fo.fu] & ['õ.bu] & ['ma.kv] \\
\hline 8 G. A. $/ 1 ; 8$ & ['ã.pa.de] & ['a.vI] & $\begin{array}{l}\text { ['o.tu.lv] } \\
\end{array}$ & ['fo.ku] & [õ] & ['ma.sI] \\
\hline 8 L. G. $/ 1 ; 9$ & ['ã.pe] & ['a.ve] & ['o.kv] & ['fo.fil & ['õ.bu] & [ma] \\
\hline 9 A. F.1;10 & ['ã.pr] & ['a.vI] & --- & ['fo.fu] & ['õ.bu] & ['ma.3I] \\
\hline 10 J. H./1;11 & ['ã.pr] & ['aj.vI] & ['o.ku] & ['fos.fu] & ['õ.d3I] & ['ma.zi.kv] \\
\hline 11 G. V. $/ 2 ; 0$ & ['ã.pa.de] & ['a.vi] & ['o.kv] & ['fos.fu] & [‘õ.bIs] & ['ma.zi.kv] \\
\hline 12 А. J. $/ 2 ; 0$ & ['lã.pa.de] & ['a.vI] & ['o.kus] & ['fos.fu.ru] & [“õ.kv] & [ma] \\
\hline
\end{tabular}




\begin{tabular}{|c|c|c|c|c|c|c|}
\hline 13 K. W./2;0 & [lã.'pa.de] & ['a.vI] & ['o.kv] & ['fos.fu] & ['õ.ti.bu] & ['ma.zi.kv] \\
\hline \begin{tabular}{|l|l}
14 J. V./2;1 \\
\end{tabular} & ['ã.pp] & ['a.vI] & ['o.kus] & ['fos.fu] & ['õ.bu] & ['ma.3I] \\
\hline 15 I. S. $/ 2 ; 1$ & ['ã.pr] & ['a.bi] & ['o.ku] & ['fo.ku] & ['õ.bI] & ['ma.3I] \\
\hline 16 C. M. $/ 2 ; 1$ & ['lã.pe] & ['a.vI] & ['o.fus] & ['po.ku] & ['õ.ku] & ['a.tfi.ku] \\
\hline 17 T. S./2;1 & [ka.'ka.ke] & ['a.vI] & --- & [pa.'pa.ke] & ['õ.bis] & ['ma.kI] \\
\hline 18 D.T. $/ 2 ; 1$ & {$[\varepsilon]$} & ['a.vI] & ['0.t $\left.\int_{I}\right]$ & [fo] & ['ã.t $\left.\int \mathrm{I}\right]$ & ['a.ke] \\
\hline 19 А. I. $/ 2 ; 2$ & ['ã.pr] & ['a.vI] & ['o.kus] & ['fos.fu] & ['õ.bu] & ['ma.3I] \\
\hline 20 M. L./2;2 & ['lã.pa.de] & ['a.vI] & ['o.kus] & ['fos.fu] & ['õ.bus] & ['ma.zi.ku] \\
\hline 21 J. C. $/ 2 ; 3$ & ['ã.pa.de] & ['la.vI] & ['do.kus] & ['lo.fo] & [o.'ni] & [ma.3i.'ku] \\
\hline 22 G. R. $/ 2 ; 4$ & ['ã.pa.de] & ['a:.vI] & ['o.kus] & ['fos.fu] & ['õ.bus] & ['ma.zi.kv] \\
\hline 23 P. S. $/ 2 ; 5$ & ['ã.pe] & ['a.vo.I] & ['o.kus] & ['fos.fu] & ['o.ni.bus] & ['ma.zi.ku] \\
\hline 24 E. P./ 2;5 & ['lã.pa.de] & ['a::.vI] & ['o.kus] & ['fo.fu] & ['õ.bus] & ['ma.zi.ku] \\
\hline 25 G.F. $/ 2 ; 6$ & ['ã.pa.de] & ['a.go.le] & ['o.ku] & ['fo.ku] & ['õ.dI] & ['ma.zi.ku] \\
\hline 26 B. F. $/ 2 ; 6$ & ['ã.pa.de] & ['a.vI] & ['o.kus] & ['fos.fu] & ['o.ni.bu] & ['ma.zi.ku] \\
\hline 27 V. S./2;7 & [i.'ã.pe] & ['aw.rI] & ['o.ku] & ['fo.fu] & ['õ.bus] & ['ma.zi.ku] \\
\hline $28 \mathrm{~J} . \mathrm{O} . / 2 ; 7$ & ['lã.pe] & ['a.vu.I] & ['o.fus] & ['fo.fu] & ['o.ni.bu] & ['ma.zi.ku] \\
\hline 29 G. S./2;7 & ['lã.pe] & ['aj.vI] & ['o.kv] & ['fo.fu.ru] & ['õ.bus] & ['ma.zi.ku] \\
\hline 30 V.S. $/ 2 ; 7$ & ['Iã.pa.de] & ['a.vu.II] & ['o.tus] & ['fos.fu] & ['o.ni.bu] & ['ma.zi.kv] \\
\hline 31 D. C./2;7 & ['lã.pa.de] & ['a.vI] & ['o.ku.lus] & ['fos.ku.ru] & ['õ.bus] & ['ma.zi.ku] \\
\hline 32.J. V. P./2;7 & ['lã.pa.de] & ['a.vI] & ['o.ku] & ['fos.fu] & ['o.ni.bu] & ['ma.zi.kv] \\
\hline 33 C. A. $/ 2 ; 8$ & ['lã.pa.de] & ['a.vo.re] & ['o.ku] & ['fo.fu] & ['õ.ni.bu] & ['ma.zi.ku] \\
\hline 34 M. S. $/ 2 ; 8$ & ['Iã.pa.de] & ['a.vo.re] & ['o.kv] & ['fos.fo] & ['o.ni.bu] & ['ma.zi.kv] \\
\hline 35 O. G. $/ 2 ; 9$ & ['lã.pa.de] & ['a.vo.re] & ['o.ku] & ['fo.fu.ru] & ['o.ni.bu] & ['ma.zi.ku] \\
\hline 36 A. L.D.;2;9 & ['lã.pa.de] & ['a.vo.I] & ['0.ku] & ['fo.fu] & ['õ.bus] & ['ma.zi.ku] \\
\hline 37 R. S./2;10 & ['lã.pa.de] & ['a.vI] & ['o.tfi.ku] & ['fo.ru] & ['õ.bus] & ['ma.zi.ku] \\
\hline 38 A. B. V./2;10 & ['lã.pa.de] & ['a.vI] & ['o.ku.v] & ['fos.ku] & ['õ.bus] & ['ma.zi.ku] \\
\hline 39 P. S./ 2;11 & ['lã.pa.dv] & ['a.vu.I] & ['o.kus] & ['fo.ku] & [‘õ.ni.bu] & ['ma.zi.kv] \\
\hline 40 P.H./2;11 & ['lã.pa.de] & ['a.vo.rI] & ['0.ku] & ['fo.fo.ru] & [o.ni.'bo] & ['ma.zi.ku] \\
\hline 41 J. S./3;0 & ['lã.pa.dv] & ['a.vo.rI] & ['o.kv] & ['fo.fo.ru] & ['õ.bus] & ['ma.zi.kv] \\
\hline 42 J. R. / 3;0 & ['lã.pa.de] & ['a.vo.rI] & ['o.ku.lus] & ['fos.ku] & ['õ.ni.bu] & ['ma.zi.ku] \\
\hline
\end{tabular}

\section{WSW}

\begin{tabular}{|c|c|c|c|c|c|c|}
\hline Criança/Idade & estrela & boneca & girafa & cachorro & dinheiro & sapato \\
\hline 1 P. C./ $1 ; 5$ & [te] & {$[\varepsilon]$} & --- & [ow] & --- & --- \\
\hline 2 L. G. $/ 1 ; 5$ & --- & --- & [a] & ['pa.pe] & [di] & -- \\
\hline 3 T. S. $/ 1 ; 6$ & [i.'si.Ie] & ['e.ke] & ['a.fe] & ['ko.u] & ['e.lv] & ['pa.tu] \\
\hline 4 Р. М. / 1;7 & --- & ['e.e.e] & [i.'a] & [ow] & [d $\mathrm{d} i]$ & [pa] \\
\hline 5 E. S./1;8 & ['te.le] & ['ع.ke] & [zi.'wa.fe] & ['So.v] & [dżi.'e.lu] & ['pa.tu] \\
\hline 6 J. P. $/ 1 ; 8$ & ['te.jp] & [bo.'ne.ke] & ['a.fv] & ['ko.v] & --- & [pa] \\
\hline 8 G. A. $/ 1 ; 8$ & [a'te.je] & ['ne.ke] & [i.'a.te] & ['ka.ke] & [dzi.'ẽ .v] & ['pa.tu] \\
\hline 8 L. G. $/ 1 ; 9$ & [e.'te] & ['ne.ke] & ['a.fe] & ['So.v] & ['e.u] & ['pa.to] \\
\hline 9 A. F.1;10 & ['te.lv] & ['ne.ke] & [i.'a.fe] & [ka.'so.v] & [dzi.'ẽ .v] & ['pa.tu] \\
\hline 10 J. H./1;11 & ['te.le] & ['ne.ke] & ['a.fe] & ['kow.v] & ['e.u] & ['pa.tu] \\
\hline 11 G. V./2;0 & [e.'te.jp] & [bu.'ne.ke] & [i.'a.fe] & [ka.'so.v] & [dzi.'. & [sa.'pa.tu] \\
\hline 12 А. J./2;0 & ['te.le] & [bo.'ne.ke] & [zi.'ra.fv] & [ka.'to.xu] & [dzi.'ej.ru] & [sa.'pa.to] \\
\hline
\end{tabular}




\begin{tabular}{|c|c|c|c|c|c|c|}
\hline $13 \mathrm{~K} . \mathrm{W} . / 2 ; 0$ & ['te.lp] & ['ne.ke] & ['a.fe] & ['ow.v] & ['e.lu] & ['pa.tv] \\
\hline 14 J. V./2;1 & ['te.le] & ['ne.ke] & [i.'a.fp] & [ka.'so.v] & [dżi.'e.lv] & [sa.'pa.tv] \\
\hline 15 I. S. $/ 2 ; 1$ & ['te.le] & ['ne.ke] & [i.'na.fe] & ['to.v] & 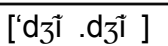 & ['ta.to] \\
\hline 16 C. M. $/ 2 ; 1$ & ['te.lv] & [ba.'c.ke] & [3u.'la.fe] & [ka.'tfo.xu] & [dfi.'ej.ru] & [ka.'pa.tv] \\
\hline 17 T. S. $/ 2 ; 1$ & ['te.te] & ['ne.ke] & [i.'a.fe] & [kaj.'So.u] & [dzi.'e.lu] & [sa.'pa.tu] \\
\hline 18 D.T. $/ 2 ; 1$ & {$[\mathrm{te}]$} & {$\left[{ }^{\prime} \varepsilon . \mathrm{kr}\right]$} & ['a.fe] & ['ka.v] & [i.'e] & ['pa.tu] \\
\hline 19 А. I. $/ 2 ; 2$ & ['te.jp] & [bu.'nc.ke] & [i.'a.fe] & [ka.'So.v] & [dfi.'ej.ru] & [sa.'pa.to] \\
\hline 20 M. L. $/ 2 ; 2$ & ['te.lp] & [bu.'nc.ke] & [3i.'a.fe] & [ka.'So.v] & [dzi.'e.v] & [pa.'pa.to] \\
\hline 21 J. C. $/ 2 ; 3$ & ['te.le] & ['ne.ke] & ['ra.fe] & [ka.'So.v] & [di.'ej.rv] & [pa.'pa.tu] \\
\hline 22 G. R. $/ 2 ; 4$ & [e.'te.le] & ['ne.ke] & [3i.'a.fv] & [ka.'Jo.u] & [dzi.'e.u] & ['pa.tu] \\
\hline 23 P. S. $/ 2 ; 5$ & [te.'la] & [bo.'nc.ke] & [3i.'ra.fe] & [ka.'So.xu] & [di.'ej.rv] & [sa.'pa.tu] \\
\hline 24 E. P./ 2;5 & [i.'te.le] & [bu.'ne.ke] & [zi.'ra.fe] & [ka.'Jo.u] & [dzi.'e.u] & ['pa.to] \\
\hline 25 G.F. $/ 2 ; 6$ & ['te.le] & {$[$ ['ne.ke] } & ['a.kp] & [ka.'tfo.u] & $\overline{\text { [dfi.'ej.ru] }}$ & [sa.'pa.tu] \\
\hline 26 B. F. $/ 2 ; 6$ & [e.'te.lv] & [bu.'ne.ke] & [3i.'a.fp] & [ka.'So.v] & [d]i.'ej.ru] & [sa.'pa.tu] \\
\hline 27 V. S./2;7 & [e.'te.le] & [bu.'nc.ke] & [3i.'la.fe] & [ka.'So.xu] & [dzi.'e.lu] & [sa.'pa.tu] \\
\hline 28 J. O./2;7 & ['te.lp] & [bu'ne.ke] & [3i.'ra.fe] & [ka.'So.xu] & [dfi.'ej.ru] & [sa.'pa.tu] \\
\hline 29 G. S. $/ 2 ; 7$ & ['te.le] & [bu'ne.ke] & [3i.'ra.fv] & [ka.'So.v] & [dfi.'ej.lu] & [sa.'pa.tu] \\
\hline 30 V.S. $/ 2 ; 7$ & [is.'te.lp] & [bu'ne.ke] & [3i.'ra.fe] & [ka.'So.xu] & [dżi.'e.lv] & [sa.'pa.tu] \\
\hline 31 D. C. $/ 2 ; 7$ & [is.'te.le] & [bo.'ne.ke] & [zi.'ra.fe] & [ka.'So.xv] & [di.'ej.ru] & [sa.'pa.tu] \\
\hline 32.J. V. P./2;7 & [i.'te.It] & [bu.'nc.ke] & [3i.'la.fe] & [ka.'So.xu] & [dzi.'e.ru] & [sa.'pa.tu] \\
\hline 33 C. А. $/ 2 ; 8$ & [is.'te.lv] & [bo.'ne.ke] & [zi.'ra.fv] & [ka.'fo.v] & [dzi.'e.ru] & [sa.'pa.tu] \\
\hline 34 M. S. $/ 2 ; 8$ & [is.'te.le] & [bu.'nc.ke] & [3i.'ra.fe] & [ka.'So.xu] & [dfi.'ej.lv] & [sa.'pa.tu] \\
\hline 35 O. G. $/ 2 ; 9$ & [is.'te.lv] & [bu.'ne.ke] & [zi.'ra.fv] & [ka.'So.xu] & [dzi.'e.ru] & [sa.'pa.tu] \\
\hline 36 A. L.D.;2;9 & [e.'tz.le] & [bu.'ne.ke] & [3i.'a.fe] & [Si.'so] & [dzi.'e.ru] & [pa.'pa.tu] \\
\hline 37 R. S./2;10 & [is.'te.lv] & [bu.'ne.ke] & [zi.'ra.fe] & [ka.'So.xu] & [dzi.'ne.ru] & [sa.'pa.tu] \\
\hline 38 A. B. V./2;10 & [is.'te.le] & [bu.'ne.ke] & [3i.'ra.fe] & [ka.'Jo.xu] & [dzi.'je] & [sa.'pa.tu] \\
\hline 39 P. S./ $2 ; 11$ & [e.'te.le] & [bu.'nc.kv] & [3i.'ra.fe] & [ka.'So.xu] & [dzi.'e.ru] & [sa.'pa.tu] \\
\hline 40 Р.Н./2;11 & [es.'te.le] & [bu.'ne.kv] & [zi.'ra.fp] & [ka.'So.xu] & [dzi.'ne..ru] & [sa.'pa.tu] \\
\hline 41 J. S./3;0 & [es.'te.le] & [bu.'nc.ke] & [3i.'ra.fe] & [ka.'So.xu] & [dzi.'ne.ru] & [sa.'pa.tu] \\
\hline 42 J. R. / 3;0 & [is.'te.le] & ['ne.ke] & [zi.'ra.fe] & [ka.'So.xu] & [di.'ej.ru] & [sa.'pa.tu] \\
\hline
\end{tabular}

\section{WWS}

\begin{tabular}{|c|c|c|c|c|c|c|}
\hline Criança/Idade & violão & jacaré & bambolê & caminhão & avião & macarrão \\
\hline 1 P. C./ 1;5 & --- & {$[\varepsilon]$} & {$[\mathrm{e}]$} & ['aw] & --- & --- \\
\hline 2 L. G./1;5 & --- & {$[\varepsilon]$} & [e] & ['aw] & --- & [ka.'ka] \\
\hline 3 T. S./1;6 & [ãw] & --- & --- & [i.'ãw] & [i.'ãw] & [ka.'ãw] \\
\hline 4 P. М. / 1;7 & [ãw] & {$[\varepsilon]$} & [e] & ['aw] & ['aw] & [a.'ãw] \\
\hline 5 E. S./1;8 & [vi] & [u.'Iz] & [bu.''le] & [ka.'jãw] & $\begin{array}{l}\text { [o.i.'ãw] } \\
\end{array}$ & [u.a.'ãw] \\
\hline 6 J. P. $/ 1 ; 8$ & [ãw] & {$[\mathrm{b} \varepsilon]$} & [be] & ['kã.v] & [ãw] & [jãw] \\
\hline 8 G. A. $/ 1 ; 8$ & [a.'ãw] & $\begin{array}{l}\text { [a.ka.'je] } \\
\end{array}$ & [bu.'le] & [ka.mi.'ãw] & [i.'ãw] & [ka.'ãw] \\
\hline 8 L. G. $/ 1 ; 9$ & [o.'ãw] & [i.'e] & [a.i.'e] & [i.'ãw] & [va.'vaw] & [ka.'ãw] \\
\hline 9 A. F.1;10 & [o.'ãw] & [ka.'je] & [bo.'le] & [i.'ãw] & [i.'ãw] & [ka.'ãw] \\
\hline 10 J. H./1;11 & [ãw] & [ka.'e] & [bã.'le] & [i.'ãw] & [vi.'ãw] & [ka.'ãw] \\
\hline 11 G. V./2;0 & [o.'lãw] & [a.ka.'je] & [bo.'le] & [ka.mi.'ãw] & [vi.'ãw] & [ka.'ãw] \\
\hline 12 А. J. $/ 2 ; 0$ & [vi.o.'lãw] & [3a.ka.'re] & [bã.bo.'le] & [ka.mi.'jãw] & [vi.'ãw] & [ma.ka.'xãw] \\
\hline
\end{tabular}




\begin{tabular}{|c|c|c|c|c|c|c|}
\hline 13 K. W. $/ 2 ; 0$ & [ãw] & {$[\varepsilon]$} & [le] & [i.'ãw] & [vi.'ãw] & [ãw] \\
\hline 14 J. V./2;1 & [ãw] & 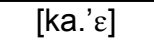 & [bo.'le] & [i.'ãw] & [vi.'ãw] & [ka.'ãw] \\
\hline 15 I. S./2;1 & [bo] & [kaj.' 'c] & [bo.'le] & [i.'ãw] & [vi.'ãw] & [ka.'ãw] \\
\hline 16 C. M./2;1 & [va] & [ka.'le] & [bo.'le] & [na] & [vi.'a] & [ka.'ãw] \\
\hline 17 T. S. $/ 2 ; 1$ & [li.'lãw] & [ka.'le] & [bo.'e] & [mi.'nãw] & [va.vi.'ãw] & [ka.'xãw] \\
\hline 18 D.T. $/ 2 ; 1$ & [ãw] & {$[\varepsilon]$} & [ne] & [pa] & [ãw] & {$[\varepsilon]$} \\
\hline 19 A. I./2;2 & [o.'lãw] & [ka.'le] & [bo.'le] & [ka.mi.'jãw] & [vi.'ãw] & [ka.'ãw] \\
\hline 20 M. L./2;2 & [i.o.'lãw] & [3a.ka.'e] & [bã.bo.'e] & [ka.mi.'jãw] & [vi.'ãw] & [ma.ka.'ãw] \\
\hline 21 J. C. $/ 2 ; 3$ & [lãw] & [ka.'re] & [bo.'le] & [ka.i.'ãw] & [vi.'ãw] & [u.'ãw] \\
\hline 22 G. R. $/ 2 ; 4$ & $\begin{array}{l}\text { [vi.'ãw] } \\
\end{array}$ & [ka.'re] & [bo.'le] & $\begin{array}{l}\text { [i.'ãw] } \\
\end{array}$ & [vi.'ãw] & [ma.ka.'ãw] \\
\hline 23 P. S. $/ 2 ; 5$ & [vi.o.'lãw] & [3a.ka.'re] & [bã.bo.'le] & [ka.mi.'jãw] & [a.vi.'ãw] & [ma.ka.'ãw] \\
\hline 24 E. P./ 2;5 & [vi.o.'Iãw] & {$\left[3^{\varepsilon}\right]$} & [bo.'le] & [ka.mi.'jãw] & [vi.'ãw] & [xãw] \\
\hline 25 G.F./2;6 & [vi.o.'Iãw] & [3a.ka.'le] & [le.'le] & [ka.mi.'jãw] & [vi.'ãw] & [ãw] \\
\hline 26 B. F. $/ 2 ; 6$ & [vi.o.'Iãw] & [3a.ka.'e] & [bo.'le] & [ka.mi.'jãw] & [vi.'ãw] & [ka.'ãw] \\
\hline 27 V. S. $/ 2 ; 7$ & [i.o.'Iãw] & [за.ka.'re] & [bo.'le] & [ka.mi.'jãw] & [vi.'ãw] & [ka.'ãw] \\
\hline 28 J. O./2;7 & [vi.'lãw] & [3a.ka.'re] & [bu.bu.'le] & [mi.'jãw] & [vi.'ãw] & [ma.ka.'xãw] \\
\hline 29 G. S. $/ 2 ; 7$ & [bo.'lãw] & [за.ka.'re] & [bo.'le] & [ka.mi.'nãw] & [vi.'ãw] & [ma.ka.'ãw] \\
\hline 30 V.S. $/ 2 ; 7$ & [vi.o.'lãw] & [3a.ka.'le] & [bã.bo.'le] & [ka.mi.'nãw] & [a.vi.'ãw] & [ka.'xãw] \\
\hline 31 D. C. $/ 2 ; 7$ & [vi.o.'lãw] & [3a.ka.'re] & [bã.bo.'le] & [ka.mi.'jãw] & [a.vi.'jãw] & [ma.ka.'xãw] \\
\hline 32.J. V. P./2;7 & [vi.o.'Iãw] & [3a.ka.'le] & [bã.bo.'le] & [ka.mi.'nãw] & [vi'ãw] & [ma.ka.'ãw] \\
\hline 33 С. A. $/ 2 ; 8$ & [vi.o.'lãw] & [3a.ka.'le] & [bã.bo.'le] & [ka.mi.'jãw] & [vi'ãw] & [ma.ka.'ãw] \\
\hline 34 M. S. $/ 2 ; 8$ & [vi.o.'lãw] & [3a.ka.'re] & [bã.bo.'le] & [ka.mi.'nãw] & [a.vi.'ãw] & [ma.ka.'xãw] \\
\hline 35 O. G./2;9 & [vi.o.'Iãw] & [3a.ka.'re] & [bã.bo.'le] & [ka.mi.'nãw] & [a.vi.'ãw] & [ma.ka.'xãw] \\
\hline 36 A. L.D.;2;9 & [vo.'lãw] & [ka.'e] & [bo.'le] & [ka.mi.'nãw] & [a.vi.'ãw] & [ma.ka.'ãw] \\
\hline 37 R. S. $/ 2 ; 10$ & [vi.o.'Iãw] & [зa.ka.'re] & [bã.bo.'le] & [ka.mi.'nãw] & [a.vi.'ãw] & [ma.ka.'ãw] \\
\hline 38 A. B. V./2;10 & [vi.vi.'ãw] & [3a.ka.'re] & [bã.bo.'le] & [ka.mi.'ãw] & [a.vi.'ãw] & [ma.ka.'xãw] \\
\hline 39 P. S./ 2;11 & [vi.'ãw] & [3a.ka.'re] & [bã.bo.'le] & [ka.mi.'jãw] & [a.vi.'ãw] & [ma.ka.'xãw] \\
\hline 40 P.Н./2;11 & [ve.lo.'Iãw] & [за.ka.'re] & [bã.bo.'le] & [ka.mi.'nãw] & [a.vi.'ãw] & [ma.ka.'xãw] \\
\hline 41 J. S. $/ 3 ; 0$ & [vi.o.'lãw] & [3a.ka.'re] & [bã.bo.'le] & [ka.mi.'nãw] & [a.vi.'ãw] & [ma.ka.'xãw] \\
\hline 42 J. R. / 3;0 & [vi.o.'Iãw] & [kaj.'z] & [bã.bo.'le] & [ka.mi.'jãw] & [a.vi.'ãw] & [ma.ka.'ãw] \\
\hline
\end{tabular}

\subsection{Anexo 3: dados naturalísticos (DES)}

\section{$1 ; 5.16$}

Nomes

Produção Infantil

Forma Alvo

\begin{tabular}{|c|c|}
\hline [a.'nã] & Sabão \\
\hline [mã] & Mãe \\
\hline [maj] & Mãe \\
\hline [mã.'mã] & Mãe \\
\hline ['u.fI] & Urso \\
\hline [li] & Livro \\
\hline [tu.'li] & Livro da Mônica \\
\hline [li.'vĩ ] & livrinho \\
\hline ['pe.t] I] & Pássaro \\
\hline
\end{tabular}




\begin{tabular}{|c|c|}
\hline ['ku.ke] & Coelho \\
\hline [ku.'ka] & Coelho \\
\hline [pe.'ni] & Coelho \\
\hline ['ka.ke] & Lixo \\
\hline ['mõ.ke] & Mônica \\
\hline ['xa.tu] & Rato \\
\hline [bu.'ni] & Bonito \\
\hline [pa] & Pai \\
\hline [paj.'e] & Pai \\
\hline [pa.'pa] & Pai \\
\hline [pa.paj.'e] & Pai \\
\hline [ge] & Miguel \\
\hline [ne.'ne] & Nenê \\
\hline [pa.'pa] & Comida \\
\hline [nĩ ] & Menino \\
\hline [a.'mi] & Menino \\
\hline [bu.'ni.tu] & Bonito \\
\hline [a.'ki] & Aqui \\
\hline [lu.'lu] & Lulu (nome) \\
\hline [lu.'li] & Luli (nome) \\
\hline [ki.'ka] & Mônica \\
\hline [ka.'ka] & Cascão \\
\hline ['ka.ke] & Lixo \\
\hline [lif] & Lixo \\
\hline [pe] & Pássaro \\
\hline [pi.'pi] & Pássaro \\
\hline [ko] & Cocô \\
\hline [ko.'ku] & Cocô \\
\hline [ko.'ko] & Cocô \\
\hline ['e.v] & Coelho \\
\hline ['po.te] & Porta \\
\hline [ba] & Bola \\
\hline [bo] & Bola \\
\hline ['bo.e] & Bola \\
\hline [pu] & Puff \\
\hline [ka.'ka] & Carro \\
\hline [ga] & Gato \\
\hline [a.ka] & Gato \\
\hline [pa.'pa] & Pai \\
\hline [pe] & Pêra \\
\hline [mã] & Mãe \\
\hline [mã.'mã] & Mãe \\
\hline ['li.bu] & Livro \\
\hline [ki.'pa] & Livro de natal \\
\hline ['de.tI] & Leite \\
\hline ['u.su] & Urso \\
\hline [ta.'ta] & Chulé \\
\hline [fi] & Fita \\
\hline [ka.'ka] & Fralda \\
\hline
\end{tabular}

\section{Verbos}




\section{Produção Infantil}

\begin{tabular}{|c|c|}
\hline [na.'na] & Nanar \\
\hline [ba] & Bate \\
\hline$[\varepsilon]$ & É \\
\hline [bĩ l'ka] & Brincar \\
\hline$[\mathrm{k} \varepsilon]$ & Quer \\
\hline [pa.'pa] & Papar \\
\hline [pa.'po] & Papou \\
\hline [ba.'na] & Banhar \\
\hline [ne.'ne] & Comer \\
\hline ['sẽ .te] & Senta \\
\hline [fa.'la] & Falar \\
\hline [ta] & Está \\
\hline [to] & Estou \\
\hline [te.da.'u] & Estudar \\
\hline
\end{tabular}

\section{$1 ; 6.22$}

Nomes

\section{Produção Infantil}

\begin{tabular}{|c|c|}
\hline [bu.'bu] & Livro \\
\hline ['to.te] & Torta \\
\hline [oj] & $\mathrm{Oi}$ \\
\hline [aj] & Pai \\
\hline [pa.'paj] & Pai \\
\hline [pa.paj.'e] & Pai \\
\hline [bo] & Bola \\
\hline ['bo.de] & Bola \\
\hline [tu.'tu] & Corneta \\
\hline [kaw] & Carro \\
\hline ['ka.xu] & Carro \\
\hline$\left[\mathrm{ku} .^{\prime} \varepsilon\right]$ & Chaminé \\
\hline ['po.te] & Porta \\
\hline ['ã.gI] & Laranja \\
\hline [u.'gu] & Miguel \\
\hline
\end{tabular}

\section{Verbos}

\section{Produção Infantil}

Forma Alvo

\begin{tabular}{|l|l|}
\hline$[$ sẽ .'ta] & Sentar \\
\hline$[\varepsilon]$ & É \\
\hline$[\mathrm{bi}]$ & Abrir \\
\hline$[\mathrm{a}$. 'bi $]$ & Abrir \\
\hline$[$ 'a.bi $]$ & Abre \\
\hline
\end{tabular}

\section{Forma Alvo}




\begin{tabular}{|l|l|}
\hline$[$ a.''bi.lu] & Abre \\
\hline$[\mathrm{ka}]$ & Quer \\
\hline$[\mathrm{ka.be}$. 'i $]$ & Acabei \\
\hline$[$ ka.bu.'i] & Acabou \\
\hline$\left[\mathrm{ka} .{ }^{\prime} \mathrm{iw}\right]$ & Caiu \\
\hline$[$ e.'ga] & Pegar \\
\hline [sa.'i] & Saiu \\
\hline
\end{tabular}

\section{1;7.12}

Nomes

Produção Infantil

Forma Alvo

\begin{tabular}{|c|c|}
\hline [ta] & Porta \\
\hline [bo] & Bola \\
\hline ['u.fil] & Puff \\
\hline [ew] & $\mathrm{Eu}$ \\
\hline [ne] & Nenê \\
\hline [ne.'nẽ j] & Nenê \\
\hline$[\mathrm{mãw}]$ & Irmão \\
\hline [fo.je] & Folha \\
\hline [bẽ j] & Bem \\
\hline ['ko;pe] & Copo \\
\hline ['so.nu] & Sono \\
\hline [ba.'i] & Barril \\
\hline ['ku.ko] & Suco \\
\hline [vi.'ãw] & Avião \\
\hline [ko.'ko] & Cocô \\
\hline ['i.su] & Isso \\
\hline ['i.tu] & Isso \\
\hline [ka.'bi] & Cabelo \\
\hline [mãj] & Mãe \\
\hline [ka.'ko] & Casaco \\
\hline ['ka.ko] & Casaco \\
\hline [bi] & Bicho \\
\hline ['ka.u] & Carro \\
\hline ['ke.ke] & Rebeca \\
\hline ['fo.tu] & Foto \\
\hline [te.'te] & Peteca \\
\hline [ã.u.'lu] & Canguru \\
\hline
\end{tabular}

\section{Verbos}




\section{Produção Infantil}

\begin{tabular}{|c|c|}
\hline [a.'bi] & Abrir \\
\hline [bi] & Abrir \\
\hline [bi.'u] & Abriu \\
\hline [ta] & Está \\
\hline [sej] & Sei \\
\hline [na.'na] & Nanar \\
\hline$[k \varepsilon]$ & Quero \\
\hline [ka] & Quero \\
\hline ['kz.iw] & Quero \\
\hline [ka.'iw] & Caiu \\
\hline [vai] & Vai \\
\hline [to] & Estou \\
\hline [pẽ .'te.iw] & Penteio \\
\hline [bi] & Subir \\
\hline [bi.'bi] & Subir \\
\hline [ka.'iw] & Caiu \\
\hline [o.'ga] & Jogar \\
\hline ['pe.ge] & Pega \\
\hline
\end{tabular}

\section{1;8.16}

Nomes

Produção Infantil

Forma Alvo

\begin{tabular}{|c|c|}
\hline [fi] & Fita \\
\hline ['i.te] & Fita \\
\hline ['fi.te] & Fita \\
\hline [bo] & Bola \\
\hline ['bo.le] & Bola \\
\hline$[\mathrm{b}, j]$ & Bolinha \\
\hline [pa.'pa] & Comida \\
\hline [bu.'bu] & Comida \\
\hline ['we.t5 I] & Sabonete \\
\hline ['pa.tu] & Pato \\
\hline a.'́ki] & Aqui \\
\hline ['bi. of u] & Bicho \\
\hline [vo.'vo] & Avô / Vovô \\
\hline [vo] & Avô/Vovô \\
\hline [ow.'o] & Avô/Vovô \\
\hline [bo.'bo] & Avô/Vovô \\
\hline [pi.'pa] & Pipa \\
\hline [pi] & Pipa \\
\hline [ko.'ko] & Cocô \\
\hline [mãw] & Irmão \\
\hline ['e.sI] & Peixe \\
\hline ['ke.3v] & Queijo \\
\hline [ne.'nẽ j] & Nenế \\
\hline [pa.'tu] & Sapato \\
\hline
\end{tabular}




\begin{tabular}{|l|l|}
\hline ['pe.te] & Chupeta \\
\hline ['a.gu.aj] & Água \\
\hline$\left[{ }^{\prime a}\right.$.gwe] & Água \\
\hline [a.'a] & Água \\
\hline ['a.ge] & Água \\
\hline [ti] & Tio \\
\hline ['ba.su] & Braço \\
\hline [t]i.'aw] & Tchau \\
\hline [wẽ ] & Wendy \\
\hline [pa.'paj] & Pai \\
\hline [ko] & Coração \\
\hline [vê.ku.'a] & Vaca \\
\hline & \\
\hline
\end{tabular}

\section{Verbos}

\section{Produção Infantil}

\begin{tabular}{|c|c|}
\hline [a.'bi] & Abrir \\
\hline [a.'bli] & Abrir \\
\hline ['a.bi] & Abre \\
\hline [põj] & Põe \\
\hline [põ] & Põe \\
\hline [ع] & É \\
\hline ['E.ge] & Pega \\
\hline ['pe.gI] & Pega \\
\hline ['sẽ .te] & Senta \\
\hline [na.'na] & Nanar (dormir) \\
\hline [na.'nã.du] & Nanando (dormindo) \\
\hline [tẽ j] & Tem \\
\hline [fé.'So] & Fechou \\
\hline ['fe.su] & Fechou \\
\hline$[\mathrm{k \varepsilon w}]$ & Quero \\
\hline [fuj] & Fui \\
\hline
\end{tabular}

\section{$1 ; 9.21$}

Nomes

\section{Produção Infantil}

\begin{tabular}{|l|l|}
\hline ['va.ke] & Vaca \\
\hline [pa.'paj] & Pai \\
\hline [pa] & Pai \\
\hline [aj] & Pai \\
\hline [ka.'vaw] & Cavalo \\
\hline [ka.'va.lv] & Cavalo \\
\hline [mãw] & Irmão \\
\hline [is.'ka] & Ovelha \\
\hline ['bej.e] & Ovelha \\
\hline
\end{tabular}

\section{Forma Alvo}




\begin{tabular}{|c|c|}
\hline ['ve.e] & Ovelha \\
\hline [ve] & Ovelha \\
\hline [pã] & Pão \\
\hline [gej] & Miguel \\
\hline [ti.'ta] & Porco \\
\hline ['pa.tu] & Pato \\
\hline ['bo.de] & Boca \\
\hline [ne.'ne] & Nenê \\
\hline [maj] & Mãe \\
\hline ['pa.tu] & Sapato \\
\hline ['xa.tu] & Rato \\
\hline ['ga.ku] & Rato \\
\hline [mãw] & Mão \\
\hline [bi.'bi] & Coruja \\
\hline [ba.'ba] & Abelha \\
\hline [a.'be.je] & Abelha \\
\hline [a.'wa] & Água \\
\hline ['mi.kI] & Mickey \\
\hline ['mi.ku] & Mickey \\
\hline [mi] & Mickey \\
\hline [mãw] & Mão \\
\hline ['fi.e] & Filha \\
\hline [to.'Si.ne] & Bolsinha \\
\hline$[\mathrm{kaw}]$ & Carro \\
\hline [ko.'ko] & Galo \\
\hline ['tẽ j.t $\mathrm{I}$ I] & Quente \\
\hline
\end{tabular}

\section{Verbos}

\section{Produção Infantil}

\begin{tabular}{|c|c|}
\hline ['kõ.dSI] & Esconde \\
\hline ['a.bi] & Abre \\
\hline [a.'bi] & Abrir \\
\hline [‘kõ.de] & Esconda \\
\hline [na.'na] & Nanar \\
\hline ['ki.ne] & Brincar \\
\hline [kaj] & Cai \\
\hline [fe.' $\left.\int \mathrm{a}\right]$ & Fechar \\
\hline ['ga.de] & Guarda \\
\hline [ka.'bu] & Acabou \\
\hline [ka.'bo] & Acabou \\
\hline [tẽ j] & Tem \\
\hline [ta] & Está \\
\hline ['pe.ge] & Pega \\
\hline ['to.ke] & Toca \\
\hline [da] & Dar \\
\hline ['de.te] & Deita \\
\hline
\end{tabular}

\section{Forma Alvo}




\section{$1 ; 10.28$}

Nomes

\section{Produção Infantil}

\section{Forma Alvo}

\begin{tabular}{|c|c|}
\hline ['a.se] & Rosa \\
\hline ['aj.ze] & Rosa \\
\hline [’a.ze] & Rosa \\
\hline ['bo.le] & Bola \\
\hline [mãw] & Mão \\
\hline [ne.'ne] & Nenê \\
\hline [ne.'nẽ j] & Nenê \\
\hline ['kã.de] & Cara \\
\hline [mi.'ni.nu] & Menino \\
\hline [ni] & Menino \\
\hline ['mi.nu] & Menino \\
\hline$\left[\int \mathrm{i}^{\prime}{ }^{\prime} \mathrm{i}\right]$ & Xixi \\
\hline [ka.'be.lu] & Cabelo \\
\hline [pa.'pa] & Comida \\
\hline [nãw] & Irmão \\
\hline [mi.'mãw] & Irmão \\
\hline$\left[{ }^{\prime} \mathrm{t} \varepsilon . \mathrm{t} \int \mathrm{I}\right]$ & Quente \\
\hline [ma.'mãj] & Mãe \\
\hline [mã.'mã] & Mãe \\
\hline [pa.'paj] & Pai \\
\hline ['pe.t] i] & Peixe \\
\hline ['fi.le] & Filha \\
\hline ['o.lu] & Olho \\
\hline ['po.tu] & Pronto \\
\hline [fo.Ke] & Folha \\
\hline [pe] & Pé \\
\hline [me] & $\mathrm{Me}$ \\
\hline$[\mathrm{t} \varepsilon \mathrm{w}]$ & Tchau \\
\hline ['bi.fu] & Bicho \\
\hline ['te.t $\mathrm{I}]$ & Estrela \\
\hline
\end{tabular}

Verbos

Produção Infantil

Forma Alvo

\begin{tabular}{|l|l|}
\hline$\left[\mathrm{ka} .{ }^{\prime} \mathrm{iw}\right]$ & Caiu \\
\hline$\left[{ }^{\mathrm{b} o} . \mathrm{te}\right]$ & Bota \\
\hline$\left[{ }^{\prime a} . \mathrm{f} \mathrm{u}\right]$ & Acho \\
\hline$[\mathrm{ta}]$ & Está \\
\hline$[\mathrm{k} \varepsilon]$ & Quero \\
\hline
\end{tabular}




\begin{tabular}{|c|c|}
\hline ['kE.v] & Quero \\
\hline [t $\left.\int i^{\prime} . a\right]$ & Tirar \\
\hline [a.'`ej] & Achei \\
\hline [ka.'bo] & Acabou \\
\hline ['o.le] & Olha \\
\hline ['0.Кe] & Olha \\
\hline [da] & Dar \\
\hline [pa.'pa] & Papar \\
\hline [a.ko.'do] & Acordou \\
\hline [foj] & Foi \\
\hline ['va.te] & Volta \\
\hline [ba.'`o] & Passou \\
\hline [su.'miw] & Sumiu \\
\hline [na.'na] & Nanar \\
\hline ['fe.fe] & Fecha \\
\hline ['pu.le] & Pula \\
\hline ['de. I I] & Desce \\
\hline
\end{tabular}

\section{1;11.9}

\section{Nomes}

\section{Produção Infantil}

Forma Alvo

\begin{tabular}{|l|l|}
\hline ['fi.te] & Fita \\
\hline ['bo.le] & Bola \\
\hline ['ku.le] & Escura \\
\hline ['bu.tu] & Bonito \\
\hline ['be.je] & Abelha \\
\hline ['a.gwe] & Água \\
\hline [pa.'ka] & Papagaio \\
\hline ['bo.le] & Bola \\
\hline ['boj.le] & Bola \\
\hline [ke.'Ku] & Coelho \\
\hline [pi.'za.du] & Pesado \\
\hline [ma.'mãw] & Irmão \\
\hline [mi.a.'mãw] & Irmão \\
\hline [i.'mãw] & Irmão \\
\hline ['mi.e] & Gato \\
\hline ['i.fu] & Isso \\
\hline [pa.'pa] & Pai \\
\hline [pa.'paj] & Pai \\
\hline [mãw] & Mão \\
\hline [vo.'vo] & Avó \\
\hline [ba.'ba] & Avô \\
\hline &
\end{tabular}




\begin{tabular}{|c|c|}
\hline [vo.'vo] & Avô \\
\hline [vo] & Avô \\
\hline [fo] & Foto \\
\hline ['u.su] & Urso \\
\hline ['u.t $\left.\int u\right]$ & Urso \\
\hline ['u. $\left.\int u\right]$ & Urso \\
\hline [a.'ki] & Aqui \\
\hline 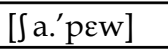 & Chapéu \\
\hline [ne.'ne] & Nenê \\
\hline [ne.'nẽ j] & Nenê \\
\hline [mãj] & Mãe \\
\hline [ma.'mãj] & Mãe \\
\hline [pa.'pa] & Comida \\
\hline [t $\mathrm{t} \mathrm{i}]$ & Tio \\
\hline [‘mi.kI] & Mickey \\
\hline [mi.'ni.nu] & Menino \\
\hline ['aj.ze] & Rosa \\
\hline ['o.ze] & Rosa \\
\hline ['ta.w] & Tchau \\
\hline [ko.'ko] & Cocô \\
\hline [pãw] & Pão \\
\hline [bo.'ne] & Boné \\
\hline
\end{tabular}

\section{Verbos}

\section{Produção Infantil}

Forma Alvo

\begin{tabular}{|c|c|}
\hline ['tẽ j] & Tem \\
\hline [na.'na] & Nanar \\
\hline [ta] & Está \\
\hline [ka.'iw] & Caiu \\
\hline ['3o.ge] & Joga \\
\hline [sa.'iw] & Saiu \\
\hline [vi] & $\overline{\mathrm{Vi}}$ \\
\hline ['a.bI] & Abre \\
\hline ['de. $\left.\int \mathrm{e}\right]$ & Deixa \\
\hline [’o.Ke] & Olha \\
\hline [t $\mathrm{s}$ i.' da] & Sentar \\
\hline [sẽ .'ta] & Sentar \\
\hline [t]i.'a] & Tirar \\
\hline [pa.'pa] & Papar \\
\hline$[\mathrm{k} \varepsilon]$ & Quero \\
\hline [lĩ .'pa] & Limpar \\
\hline [ka.'bo] & Acabou \\
\hline [gaw] & Legal \\
\hline
\end{tabular}

\section{$2 ; 0.22$}

Nomes 


\begin{tabular}{|c|c|}
\hline ['bi.su] & Bicho \\
\hline [mi'ni.nu] & Menino \\
\hline$\overline{\text { ['mi.nu] }}$ & Menino \\
\hline [ka.' o.xu] & Cachorro \\
\hline [pa.'po.pe] & Cachorro \\
\hline [kẽ j] & Quem \\
\hline [ka.'be.lu] & Cabelo \\
\hline ['fo.gu] & Fogo \\
\hline [ko.'koj] & Cocô \\
\hline [mõj] & Mãe \\
\hline [ma.'mãj] & Mãe \\
\hline [do.'doj] & Dodói \\
\hline ['o.tu] & Foto \\
\hline ['tã.pe] & Tampa \\
\hline [bĩ .'ke.du] & Brinquedo \\
\hline [mãw] & Irmão \\
\hline ['a.g g e] & Água \\
\hline ['o.dze] & Rosa \\
\hline [a.'lo] & Alô \\
\hline ['vi.de] & Vida \\
\hline ['i.e] & Fotografia \\
\hline [sa.'pa.tu] & Sapato \\
\hline ['ve.to] & Vento \\
\hline [ ji.'te.le] & Pijama \\
\hline [ko.'e] & Coelho \\
\hline ['me.ze] & Mesa \\
\hline [pa.'paj] & Pai \\
\hline ['3ẽ .ts I] & Gente \\
\hline ['dẽ j.t $\mathrm{I}]$ & Dente \\
\hline [pe] & Pedro \\
\hline [vo.'vo] & Avó \\
\hline [vo.'vo] & Avô \\
\hline [vi.'ãw] & Avião \\
\hline
\end{tabular}

\section{Verbos}

\section{Produção Infantil}

\section{Forma Alvo}

\begin{tabular}{|l|l|}
\hline$[$ foj] & Foi \\
\hline$[$ ko.'to] & Cortou \\
\hline [fa.'ze] & Fazer \\
\hline ['põj.e] & Põe \\
\hline [si.'miw] & Sumiu \\
\hline [pu.ku.'la] & Procurar \\
\hline ['pej.te] & Aperta \\
\hline ['pu. e e] & Puxa \\
\hline
\end{tabular}




\begin{tabular}{|l|l|}
\hline$[$ tẽ j] & Tem \\
\hline [bo.'ta] & Botar \\
\hline ['bo.te] & Bota \\
\hline [ka.'iw] & Caiu \\
\hline [si.'bi] & Subir \\
\hline [a.'biw] & Abriu \\
\hline ['o.le] & Olha \\
\hline [ko.'do] & Acordou \\
\hline [na.'na] & Nanar \\
\hline
\end{tabular}

\section{$2 ; 1.25$}

Nomes

\section{Produção Infantil}

\begin{tabular}{|l|l|}
\hline [ne.'ne] & Nenê \\
\hline ['fa.ke] & Faca \\
\hline [ma.'mãj] & Mãe \\
\hline [mãj] & Mãe \\
\hline [tu.'a.de] & Torrada \\
\hline ['o.vu] & Ovo \\
\hline [ko.'mi.de] & Comida \\
\hline ['kã.me] & Cama \\
\hline [pa.'paj] & Pai \\
\hline [pe.'zẽ .t] I] & Presente \\
\hline [pu.ka.'do] & Computador \\
\hline [fa.ku.'da.dr] & Faculdade \\
\hline ['li.vu] & Livro \\
\hline ['ko.be] & Cobra \\
\hline [za.'ne.le] & Janela \\
\hline [bi.'fi.nu] & Bichinho \\
\hline ['e.sI] & Peixe \\
\hline ['ka.wo] & Carro \\
\hline ['a.gwe] & Água \\
\hline ['o.ze] & Rosa \\
\hline [is.'te.le] & Estrela \\
\hline [bi.'i.tu] & Bonito \\
\hline ['ku.le] & Escura \\
\hline [sa.'bãw] & Sabão \\
\hline [mãw] & Mão \\
\hline ['fi.te] & Fita \\
\hline ['ma.3i.ku] & Mágico \\
\hline ['bu.je] & Bruxa \\
\hline [es.'to.e] & História \\
\hline ['bi.gi] & Mickey \\
\hline [to.ka.'dzi.nu] & Coitadinho \\
\hline & \\
\hline
\end{tabular}




\begin{tabular}{|l|l|}
\hline$\left[\right.$ so.'ve.t $\left.\int \mathrm{I}\right]$ & Sorvete \\
\hline$\left[\mathrm{ka} .{ }^{\prime} \varepsilon\right]$ & Café \\
\hline$[$ 'pe.te] & Chupeta \\
\hline$[$ sa.'si.se] & Salsicha \\
\hline$\left[\mathrm{ku} .{ }^{\prime} \mathrm{m \varepsilon} . \mathrm{ke}\right]$ & Boneca \\
\hline$[$ Si.'te.le] & Pijama \\
\hline
\end{tabular}

\section{Verbos}

Produção Infantil

\begin{tabular}{|c|c|}
\hline ['a. $\mathrm{Ne}]$ & Olha \\
\hline$[\mathrm{k} \varepsilon]$ & Quer \\
\hline ['pe.ge] & Pega \\
\hline [So.'ã.du] & Chorando \\
\hline 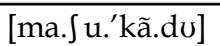 & Machucando \\
\hline [ka.'bo] & Acabou \\
\hline ['va.mu] & Vamos \\
\hline ['Je.ge] & Chega \\
\hline [ka.'i] & Cair \\
\hline ['de.se] & Deixa \\
\hline ['sẽ .te] & Senta \\
\hline [kõw.'pa] & Comprar \\
\hline [ka.'iw] & Caiu \\
\hline ['bo.te] & Bota \\
\hline [pe.'dew] & Perdeu \\
\hline [ko.'ta] & Cortar \\
\hline [mo.'jo] & Molhou \\
\hline ['nas.ge] & Rasga \\
\hline ['kas.go] & Rasgo \\
\hline [de.ze.'nã.nu] & Desenhando \\
\hline
\end{tabular}

\section{$2 ; 2.28$}

Nomes

Produção Infantil

Forma Alvo

\begin{tabular}{|l|l|}
\hline$[\mathrm{kãw}]$ & Cão \\
\hline$[$ do.'doj] & Dodói \\
\hline$\left[{ }^{\prime}\right.$ be.3u] & Beijo \\
\hline$[$ ma.'mãj] & Mãe \\
\hline$\left[{ }^{\prime}\right.$ fa.ke $]$ & Faca \\
\hline$[$ mi.'mãw] & Irmão \\
\hline$[\mathrm{zu}]$ & Azul \\
\hline
\end{tabular}




\begin{tabular}{|c|c|}
\hline ['bu. $\left.\int \mathrm{e}\right]$ & Bruxa \\
\hline [bi.ka.'de.li] & Brincadeira \\
\hline [ka.'de.le] & Cadeira \\
\hline ['ko.ze] & Coisa \\
\hline ['fej.e] & Feia \\
\hline 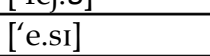 & Peixe \\
\hline ['ve.d3I] & Verde \\
\hline [ko] & Cor \\
\hline [ko.ta.'d3i.ne] & Coitadinha \\
\hline$[\mathrm{ka}$. ' o o.xu] & Cachorro \\
\hline [pa.'paj] & Pai \\
\hline [ga.'t $\int$ i.nu] & Gatinho \\
\hline [a.'sãw] & Coração \\
\hline [ko.ra.'sãw] & Coração \\
\hline [so.'da.d I] & Saudade \\
\hline [pi.ka.' $\left.\int \mathrm{u}\right]$ & Pikachu \\
\hline [mi.'ni.nu] & Menino \\
\hline ['o. $\mathrm{N} U]$ & Olho \\
\hline [lu.'lu] & Lulu \\
\hline [ba.'nã.ne] & Banana \\
\hline [ko.'ko] & Cocô \\
\hline [is.'toj.e] & História \\
\hline [fej.'ãw] & Feijão \\
\hline [ma.'ka.ku] & Macaco \\
\hline ['kã.me] & Cama \\
\hline [fiw] & Frio \\
\hline [fiw.'zi.nu] & Friozinho \\
\hline [ka.'pus] & Capuz \\
\hline ['vẽ .tu] & Vento \\
\hline [ve.'ve.le] & Novela \\
\hline [mi.'gعw] & Miguel \\
\hline ['e.lI] & Ele \\
\hline [is.'ko.le] & Escola \\
\hline ['o.ze] & Rosa \\
\hline [mãw] & Mão \\
\hline ['gã.dzI] & Grande \\
\hline [u.'sĩ w] & Ursinho \\
\hline ['kẽ .tt I] & Quente \\
\hline
\end{tabular}

\section{Verbos}

Produção Infantil

Forma Alvo

\begin{tabular}{|l|l|}
\hline ['o.Ke] & Olha \\
\hline ['bo.te] & Bota \\
\hline [gos.'ta] & Gostar \\
\hline [a.'zu.de] & Ajuda \\
\hline
\end{tabular}




\begin{tabular}{|c|c|}
\hline [Su.'ve.nv] & Chovendo \\
\hline [So.'ã.du] & Chorando \\
\hline [ku.'mẽ .dv] & Comendo \\
\hline [to.'kã.nu] & Tocando \\
\hline [ka.'iw] & Caiu \\
\hline [sa.'iw] & Saiu \\
\hline [fé.' $\mathrm{J}$ a] & Fechar \\
\hline [kõ.si.'gi] & Consegui \\
\hline$\overline{\text { [’vẽ .du] }}$ & Vendo \\
\hline [ta.'bo] & Acabou \\
\hline [pa.'as] & Passar \\
\hline [ku.'bi] & Cobrir \\
\hline ['ko.bI] & Cobre \\
\hline [foj] & Foi \\
\hline [vaj] & Vai \\
\hline ['sẽ .te] & Senta \\
\hline [pa.Se.'ã.nu] & Passeando \\
\hline [bĩ .'ka] & Brincar \\
\hline [ta] & Está \\
\hline [to] & Estou \\
\hline
\end{tabular}

\section{2;3.11}

\section{Nomes}

\section{Produção Infantil}

Forma Alvo

\begin{tabular}{|l|l|}
\hline ['e.si] & Peixe \\
\hline [bu.'ne.ku] & Boneco \\
\hline [maj] & Mãe \\
\hline [ma.'mãj] & Mãe \\
\hline [a.'ki] & Aqui \\
\hline [pa.'paj] & Pai \\
\hline [pa.pa.'zĩ ] & Papaizinho \\
\hline ['3u.ljw] & Júlio \\
\hline [mi.'gew] & Miguel \\
\hline [mi.'ni.nu] & Menino \\
\hline [do.'doj] & Dodói \\
\hline [so.'da.dzI] & Saudade \\
\hline ['i.su] & Isso \\
\hline ['fo.se] & Força \\
\hline [a.'zu.de] & Ajuda \\
\hline [ko.'ko] & Cocô \\
\hline ['va.ke] & Vaca \\
\hline [baj.'e.ge] & Barriga \\
\hline [bĩ.'ke.du] & Brinquedo \\
\hline ['boj] & Bola \\
\hline ['bo.le] & Bola \\
\hline & \\
\hline
\end{tabular}




\begin{tabular}{|c|c|}
\hline [pi.'ni.ku] & Pinico \\
\hline [pi.'zã.me] & Pijama \\
\hline [ka.J o.ĩ .nu] & Cachorrinho \\
\hline [bu.'ni] & Bonito \\
\hline [vo.'se] & Você \\
\hline ['bo.ke] & Boca \\
\hline [ko] & Cor \\
\hline ['o.ze] & Rosa \\
\hline [o.'e. $K e]$ & Orelha \\
\hline [ko.'Ke] & Colher \\
\hline [na.'is] & Nariz \\
\hline ['a.su] & Braço \\
\hline [bi.'ga.du] & Obrigado \\
\hline ['bo.lv] & Bolo \\
\hline [mi.'no.ke] & Minhoca \\
\hline [pe.da.'sĩ nu] & Pedacinho \\
\hline
\end{tabular}

\section{Verbos}

\section{Produção Infantil}

Forma Alvo

\begin{tabular}{|c|c|}
\hline [vo] & Vou \\
\hline [tẽ j] & Tem \\
\hline [ta] & Está \\
\hline$[\mathrm{k} \varepsilon]$ & Quero \\
\hline ['a.bre] & Abra \\
\hline [ko.'me] & Comer \\
\hline ['pe.sI] & Parece \\
\hline [a.'biw] & Abriu \\
\hline [ma.Ju.'ko] & Machucou \\
\hline [ka.'to] & Catou \\
\hline [ma.'sã] & Amassando \\
\hline ['o.Ke] & Olha \\
\hline [fa.'ze] & Fazer \\
\hline ['me. $\left.\int \mathrm{e}\right]$ & Mexa \\
\hline ['po.su] & Posso \\
\hline $\begin{array}{l}\left.{ }^{\prime} p \varepsilon .1 \mathrm{la}\right] \\
\end{array}$ & Espera \\
\hline ['sẽ .te] & Senta \\
\hline ['fa.se] & Faça \\
\hline
\end{tabular}

\section{$2 ; 4.16$}

\section{Nomes}




\begin{tabular}{|c|c|}
\hline [mã] & Mãe \\
\hline [ma.'mãj] & Mãe \\
\hline [dzĩ ] & Dedinho \\
\hline [’o.ze] & Rosa \\
\hline [bu.'la.ku] & Buraco \\
\hline [do.'doj] & Dodói \\
\hline [ka.'be.se] & Cabeça \\
\hline ['li.vu] & Livro \\
\hline ['u.su] & Urso \\
\hline ['ko.be] & Cobra \\
\hline ['bo.ke] & Boca \\
\hline ['gã.d3I] & Grande \\
\hline [ko.'ko] & Cocô \\
\hline ['t $\mathrm{t}$ i.gI] & Tigre \\
\hline ['fo.gu] & Fogo \\
\hline ['me.du] & Medo \\
\hline [mi.'nĩ .ne] & Menina \\
\hline [ves.'t $\mathrm{t}$ i.du] & Vestido \\
\hline ['d $.1 e]$ & Dela \\
\hline ['põ.tu] & $\begin{array}{l}\text { Pronto } \\
\end{array}$ \\
\hline [sa.bo.'ne.t5 I] & Sabonete \\
\hline ['li.f $v]$ & Lixo \\
\hline [mãw] & Mão \\
\hline [ko.fu.'zãw] & Confusão \\
\hline ['bo.le] & Bola \\
\hline ['po.te] & Porta \\
\hline [i.'o.t $[\mathrm{I}]$ & Filhote \\
\hline ['ga.tu] & Gato \\
\hline [bo.'kãw] & Bocão \\
\hline ['gã.d3I] & Grande \\
\hline [ga.'t $\mathrm{I}$ I] & Gatinho \\
\hline [bu.'ne.ku] & Boneco \\
\hline [ba.'li.je] & Balinha \\
\hline [ki.ki.'e.Ku] & Coelho \\
\hline [ba.'nã.ne] & Banana \\
\hline ['fe.re] & Feira \\
\hline [ka.'ki] & Caqui \\
\hline [me.'lãw] & Melão \\
\hline [lu.'lu] & Lulu \\
\hline [ku.'da.dv] & Cuidado \\
\hline ['i.vu] & Livro \\
\hline ['ma.le] & Mala \\
\hline [fiw] & Frio \\
\hline [ko.'le.giw] & Colégio \\
\hline [ko.la.'sãw] & Coração \\
\hline ['pe.sI] & Peixe \\
\hline [’fo.mI] & Fome \\
\hline [ku.mi.'d3̃̃ ] & Comida \\
\hline [ne.'ne] & Nenê \\
\hline
\end{tabular}




\begin{tabular}{|l|l|}
\hline [si.'nẽ .me] & Cinema \\
\hline$[$ 've.dzII] & Verde \\
\hline [э.'fã.t $\left.\int \mathrm{I}\right]$ & Elefante \\
\hline
\end{tabular}

\section{Verbos}

\section{Produção Infantil}

Forma Alvo

\begin{tabular}{|c|c|}
\hline [to] & Estou \\
\hline [ta] & Está \\
\hline [tãw] & Estão \\
\hline ['fi.zI] & Fiz \\
\hline ['a.bi] & Abre \\
\hline [०] & Olha \\
\hline ['o.Ke] & Olha \\
\hline [fa.'zẽ .du] & Fazendo \\
\hline [zu.'da] & Ajudar \\
\hline [So.'ã.du] & Chorando \\
\hline [ke.'bo] & Quebrou \\
\hline [na.'nã.du] & Nanando \\
\hline [pa.le.'sew] & Pareceu \\
\hline$[\mathrm{k} \varepsilon]$ & Quer \\
\hline [ka.'bo] & Acabou \\
\hline [si.'gu.le] & Segura \\
\hline [pu.ku.'1ã.du] & Procurando \\
\hline ['pe.ge] & Pega \\
\hline [si.'kã.du] & Secando \\
\hline ['fe. $\mathrm{fe}]$ & Fecha \\
\hline ['so.bi] & Sobre \\
\hline [bo.'ta] & Botar \\
\hline [su.'bi] & Subir \\
\hline [kõ .'po] & Comprou \\
\hline [ka.'iw] & Caiu \\
\hline [pis.'ka] & Pescar \\
\hline [pe.'tã.dv] & Apertando \\
\hline [ku.'me] & Comer \\
\hline [ku.'mẽ .du] & Comendo \\
\hline
\end{tabular}

\section{2;5.0}

Nomes

\section{Produção Infantil}

\section{Forma Alvo}

\begin{tabular}{|l|l|}
\hline$\left[\int\right.$ ej.'os] & Cheirosa \\
\hline [pi.'万ã.me] & Pijama \\
\hline ['ka.se] & Calça \\
\hline
\end{tabular}




\begin{tabular}{|c|c|}
\hline ['u.ne] & Unha \\
\hline [lu.'lu] & Lulu \\
\hline [ka.'î .ne] & Clarinha \\
\hline [ma.'mãj] & Mãe \\
\hline ['ka.ze] & Casa \\
\hline [ka.'zi.ne] & Casinha \\
\hline [is.'te.le] & Estrela \\
\hline [pa.sa.'̃̃ .nu] & Passarinho \\
\hline [vo.'se] & Você \\
\hline [kwe.'lí .ne] & Coelhinha \\
\hline [ku.'mi.de] & Comida \\
\hline$\left[\mathrm{ku} .^{\prime} \hat{\kappa} \varepsilon\right]$ & Colher \\
\hline ['o.ze] & Rosa \\
\hline [pa:.'bẽ js] & Parabéns \\
\hline ['ka.nI] & Carne \\
\hline [ka.'nĩ .ne] & Carninha \\
\hline [sa.'u.d I] & Saúde \\
\hline ['du.lv] & Duro \\
\hline [ko.'mi.de] & Comida \\
\hline [se.'mã.ne] & Semana \\
\hline ['bo.le] & Bola \\
\hline [pe] & Pé \\
\hline ['fo.se] & Força \\
\hline [le.'ãw] & Leão \\
\hline [ku.' $/ \varepsilon]$ & Colher \\
\hline ['bu.ze] & Blusa \\
\hline ['bu. e] & Bruxa \\
\hline [fu.'mi.ge] & Formiga \\
\hline [ko.'ko] & Cocô \\
\hline ['u.ve] & Uva \\
\hline [pi.ko.'le] & Picolé \\
\hline [is.'ku.lu] & Escuro \\
\hline [ba.'la] & Bala \\
\hline$\left[\int i^{\prime}{ }^{\prime} k \varepsilon . t \int \mathrm{I}\right]$ & Chiclete \\
\hline ['um.lv] & Muro \\
\hline [toj] & Torre \\
\hline [lê.'gaw] & Legal \\
\hline [bu.'ni.tu] & Bonito \\
\hline [vê.'me.wo] & Vermelho \\
\hline [a.'zu] & Azul \\
\hline [do.'doj] & Dodói \\
\hline ['um.zi] & Música \\
\hline [Su.'ka.Ku] & Chocalho \\
\hline$\left[\begin{array}{lll}\text { bi.' } \int \tilde{1} & \text {.nu] }\end{array}\right.$ & Bichinho \\
\hline [bu.'ne.ku] & Boneco \\
\hline
\end{tabular}




\section{Verbos}

Produção Infantil

\begin{tabular}{|c|c|}
\hline [fi.'ko] & Ficou \\
\hline [si.'gu.re] & Segura \\
\hline [põj] & $\begin{array}{l}\text { Põe } \\
\end{array}$ \\
\hline [’ko.mI] & Come \\
\hline [ku.'me] & Comer \\
\hline ['bo.te] & Botar \\
\hline [bo.'tã.du] & Botando \\
\hline ['gos.te] & Gosta \\
\hline [go.'to] & Gostou \\
\hline [’o. $\mathrm{Ke}]$ & Olha \\
\hline [’pe.ge] & Pega \\
\hline [fi.'ko] & Ficou \\
\hline [pĩ .'to] & Pintou \\
\hline [sej] & Achei \\
\hline$[\mathrm{k \varepsilon w}]$ & Quero \\
\hline ['kc.lv] & Quero \\
\hline [to.'ka] & Tocar \\
\hline [na.'na] & Nanar \\
\hline [pĩ .'ta] & Pintar \\
\hline [pĩ .'to] & Pintou \\
\hline [ta] & Está \\
\hline [ba.'tẽ j.dv] & Batendo \\
\hline [Se.'ga] & Chegar \\
\hline [vês.'t $\int \tilde{1}$.dv] & Vestindo \\
\hline [kõ.'si.gu] & Consigo \\
\hline [vu.'a] & Voar \\
\hline [sa.'iw] & Saiu \\
\hline [bĩ .'kã.du] & Brincando \\
\hline [su.'bĩ .dv] & Subindo \\
\hline [ka.'bej] & Acabei \\
\hline [ka.'i] & Cair \\
\hline [ka.'ĩ .du] & Caindo \\
\hline [mõ.'ta] & Montar \\
\hline [di.zi.'na] & Desenhar \\
\hline
\end{tabular}

\section{2;6.12}

Nomes 


\begin{tabular}{|c|c|}
\hline ['lu.se] & Luz \\
\hline [mi.'gعw] & Miguel \\
\hline [ko] & Cor \\
\hline [ma.'mãj] & Mãe \\
\hline [’o.ze] & Rosa \\
\hline ['ba.nu] & Banho \\
\hline [lu.'lu] & Lulu \\
\hline [do.'døj] & Dodói \\
\hline ['li.vo] & Livro \\
\hline ['i.su] & Isso \\
\hline [pa.'paj] & Pai \\
\hline ['pa.tu] & Pato \\
\hline ['bo.le] & Bola \\
\hline [ko] & Cor \\
\hline [u.ve] & Uva \\
\hline ['e.se] & Essa \\
\hline [ka.'te.lv] & Castelo \\
\hline ['ka.ze] & Casa \\
\hline [fi.'t $\left.t \int i . n e\right]$ & Fitinha \\
\hline [bi.'Si.nu] & Bichinho \\
\hline [ku.'mi.de] & Comida \\
\hline [bi'o.le] & Viola \\
\hline ['u.ve] & Uva \\
\hline [ma.'le.le] & Amarela \\
\hline [sow] & Sol \\
\hline [le.'gaw] & Legal \\
\hline ['po.te] & Porta \\
\hline [vo.'se] & Você \\
\hline ['bu.fe] & Bruxa \\
\hline [ka.'be.lu] & Cabelo \\
\hline [pa.sa.'li.nu] & Passarinho \\
\hline [ba.'li.ne] & Balinha \\
\hline [la.'ã.ze] & Laranja \\
\hline ['ba.ku] & Barco \\
\hline ['k $\left.\mathrm{k}^{\mathrm{w}} \mathrm{a} . \mathrm{tu}\right]$ & Quarto \\
\hline [a.'go.e] & Lagoa \\
\hline [nãw] & Não \\
\hline [a.'zu] & Azul \\
\hline
\end{tabular}

\section{Verbos}

Produção Infantil

Forma Alvo 


\begin{tabular}{|c|c|}
\hline ['dej.Se] & Deixa \\
\hline [bo.'ta] & Botar \\
\hline [la.'va] & Lavar \\
\hline [to.'ma] & Tomar \\
\hline [sej] & Sei \\
\hline [de.ze.'na] & Desenhar \\
\hline [kõ.'pa] & Comprar \\
\hline [ta.'lã.du] & Trabalhando \\
\hline ['va.mu] & Vamos \\
\hline ['fa.ze] & Fazer \\
\hline [to] & Estou \\
\hline [ta] & Está \\
\hline [kõ.'se.gI] & Consegui \\
\hline ['ã .me] & Ama \\
\hline [pa.'z.sI] & Parece \\
\hline [fejs] & Fez \\
\hline [pĩ .'ta] & Pintar \\
\hline [de.vo.'ve] & Devolver \\
\hline [ã.'dã.du] & Andando \\
\hline
\end{tabular}

\section{2;7.15}

\section{Nomes}

Produção Infantil

Forma Alvo

\begin{tabular}{|c|c|}
\hline [mãw] & Mão \\
\hline [pa.'paj] & Pai \\
\hline [pa.'pa] & Pai \\
\hline [ma.'mãj] & Mãe \\
\hline ['o.ze] & Rosa \\
\hline [mi'.gew] & Miguel \\
\hline [ko.'le.ziw] & Colégio \\
\hline ['o.tu] & Outro \\
\hline [pe.'ko.su] & Pescoço \\
\hline [ba.'na.ne] & Banana \\
\hline [vê.'me.ju] & Vermelho \\
\hline [pa.'pew] & Papel \\
\hline [a.'ã.ze] & Laranja \\
\hline [bi.'si.nu] & Bichinho \\
\hline [lu.'lu] & Lulu \\
\hline [ba.'le] & Balé \\
\hline [go.'to.zu] & Gostoso \\
\hline [pi.ka.' $\mathrm{u}$ ] & Pikachu \\
\hline [bu.nc.kĩ ] & Bonequinho \\
\hline [dzi.'ku.pe] & Desculpa \\
\hline [ma.'sã] & Maçã \\
\hline ['la.pI] & Lápis \\
\hline ['bã.ke] & Branca \\
\hline ['ne.vi] & Neve \\
\hline ['bu. $\left.\int e\right]$ & Bruxa \\
\hline
\end{tabular}




\begin{tabular}{|c|c|}
\hline [pe.'ko.su] & Pescoço \\
\hline ['su.ze] & Suja \\
\hline [bu.'la.ku] & Buraco \\
\hline [de.'ze.jnu] & Desenho \\
\hline [mi.'nu.to] & Minuto \\
\hline [kẽ .ts i.nu] & Quentinho \\
\hline [go.'to.zu] & Gostoso \\
\hline$\left[\int i^{\prime} \int_{I}\right]$ & Xixi \\
\hline ['u.me] & Uma \\
\hline ['koj.ze] & Coisa \\
\hline ['noj.t. I] & Noite \\
\hline [ju.'ãw] & João \\
\hline ['E.liw] & Hélio \\
\hline [bĩ .'ke.dv] & Brinquedo \\
\hline [ma.'li.e] & Maria \\
\hline [’ko.lv] & Colo \\
\hline [So.ko.'la.t I I] & Chocolate \\
\hline [ma.'si.ne] & Massinha \\
\hline [bo.'tãw] & Botão \\
\hline [sa.'pa.tu] & Sapato \\
\hline
\end{tabular}

\section{Verbos}

\section{Produção Infantil}

Forma Alvo

\begin{tabular}{|c|c|}
\hline$[\mathrm{k} \varepsilon]$ & Quero \\
\hline [fa.'ze] & Fazer \\
\hline [fa.'zẽ .du] & Fazendo \\
\hline [pe.'si.ze] & Precisa \\
\hline [di.zi.'nã.du] & Desenhando \\
\hline [to.'ka] & Trocar \\
\hline ['pe.le] & Espera \\
\hline [ve] & Ver \\
\hline [S ej] & Achei \\
\hline ['pe.ge] & Pega \\
\hline [kõ.'se.gI] & Consegue \\
\hline [kõ.'pa] & Comprar \\
\hline ['pe.te] & Aperta \\
\hline [to.'ka] & Trocar \\
\hline
\end{tabular}

\section{2;8.19}

Nomes 


\section{Produção Infantil}

Forma Alvo

\begin{tabular}{|c|c|}
\hline [ma.'mãj] & Mamãe \\
\hline [lu.'lu] & Lulu \\
\hline [bĩ .'ke.du] & Brinquedo \\
\hline ['pe.dziw] & Prédio \\
\hline ['bã.ku] & Branco \\
\hline ['ko.pe] & Copa \\
\hline ['po.te] & Porta \\
\hline $\begin{array}{l}\text { [’o.le] } \\
\end{array}$ & Hora \\
\hline ['sẽ .se] & Licença \\
\hline [ka.'so.gu] & Cachorro \\
\hline ['fo.tu] & Foto \\
\hline ['ko.lu] & Colo \\
\hline [vi.'gõ.e] & Vergonha \\
\hline ['fo.se] & Força \\
\hline [a.'3u.de] & Ajuda \\
\hline [sẽ .'ta.de] & Sentada \\
\hline ['ko.be] & Cobra \\
\hline [a.'su] & Azul \\
\hline [a.vi.'ãw] & Avião \\
\hline ['lĩ.$d e]$ & Linda \\
\hline ['sa.ku] & Saco \\
\hline$\left[\int \mathrm{i} .{ }^{\prime} \int \mathrm{i}\right]$ & Xixi \\
\hline ['fo.le] & Folha \\
\hline [ma.ka.'xãw] & Macarrão \\
\hline [’kaj.nI] & Carne \\
\hline [me.'ni.ne] & Menina \\
\hline ['pa.tu] & Pato \\
\hline ['fiw.mI] & Filme \\
\hline [bu.'ni.te] & Bonita \\
\hline [mãw] & Mão \\
\hline ['k $\left.\mathrm{k}^{\mathrm{w} a} \cdot \mathrm{tu}\right]$ & Quatro \\
\hline ['sĩ.$k u]$ & Cinco \\
\hline ['no.vi] & Nove \\
\hline ['o.tu] & Oito \\
\hline [pa:.'bẽ js] & Parabéns \\
\hline [bo.'li.ne] & Bolinha \\
\hline ['bo.lu] & Bolo \\
\hline [es.'te.le] & Estrela \\
\hline ['bu.se] & Bruxa \\
\hline [S o.ko.'la.t I I] & Chocolate \\
\hline ['pa.kI] & Parque \\
\hline [‘li.bu] & Livro \\
\hline ['ka.ze] & Casa \\
\hline [pe.ke.'ni.ne] & Pequenininha \\
\hline [do.'doj] & Dodói \\
\hline ['ka.me] & Cama \\
\hline ['bi.su] & Bicho \\
\hline ['i.su] & Bicho \\
\hline
\end{tabular}




\section{Verbos}

\section{Produção Infantil}

\begin{tabular}{|c|c|}
\hline ['po.su] & Posso \\
\hline ['po.d3I] & Pode \\
\hline [bĩ .'ka] & Brincar \\
\hline$[\mathrm{k} \varepsilon]$ & Quero \\
\hline [de.ze.'na] & Desenhar \\
\hline [ta.ba.'la] & Trabalhar \\
\hline [ka.'rI] & Cair \\
\hline [ka.'iw] & Caiu \\
\hline ['t $\left.\mathrm{t} \int \mathrm{i} . \mathrm{e}\right]$ & Tira \\
\hline [pu.'la] & Pular \\
\hline [vo] & Vou \\
\hline ['to.me] & Toma \\
\hline [ba.'sã.du] & Balançando \\
\hline [fa.'zẽ .du] & Fazendo \\
\hline [ku.me.'sã.du] & Começando \\
\hline [de.mo.'la] & Demorar \\
\hline [ko.'me] & Comer \\
\hline [la.'va] & Lavar \\
\hline [pu.'`ã.du] & Puxando \\
\hline [ko.'liw] & Coloriu \\
\hline$\left[{ }^{\prime} \mathrm{p} \varepsilon, \mathrm{le}\right]$ & Espera \\
\hline
\end{tabular}

\section{2;9.24}

Nomes

\section{Produção Infantil}

\begin{tabular}{|c|c|}
\hline [ma.'mãj] & Mãe \\
\hline ['ka.ze] & Casa \\
\hline ['su.ku] & Suco \\
\hline [a.'ã.ze] & Laranja \\
\hline ['o. $\left.\int U\right]$ & Roxo \\
\hline ['fo.e] & Fora \\
\hline ['na.de] & Nada \\
\hline ['bo.le] & Bola \\
\hline [do.'doj] & Dodói \\
\hline ['e.lI] & Ele \\
\hline ['po.te] & Porta \\
\hline [pa.'re.d3I] & Parede \\
\hline [bi.'ga.de] & Obrigada \\
\hline [bo.'ni.tu] & Bonito \\
\hline [ma.ka.'xãw] & Macarrão \\
\hline$\left[\mathrm{t} \int \mathrm{iw}\right]$ & Tio \\
\hline ['mo.su] & Almoço \\
\hline
\end{tabular}

\section{Forma Alvo}




\begin{tabular}{|c|c|}
\hline ['o.3I] & Hoje \\
\hline [fiw] & Frio \\
\hline [ka.'fe] & Café \\
\hline ['ko.pu] & Copo \\
\hline ['su.ku] & Suco \\
\hline [fu.'gãw] & Fogão \\
\hline ['do.Is] & Dois \\
\hline ['ba.su] & Braço \\
\hline [pãw] & Pão \\
\hline ['fo.mI] & Fome \\
\hline ['u.me] & Uma \\
\hline$\overline{\text { ['fi.te] }}$ & Fita \\
\hline [to.'xa.de] & Torrada \\
\hline [ba.'xi.ge] & Barriga \\
\hline$\overline{\left[{ }^{\prime} \mathrm{ka} . \mathrm{xu}\right]}$ & Carro \\
\hline [pa.'paj] & Pai \\
\hline [me.'ni.ne] & Menina \\
\hline [bo.'ne.ke] & Boneca \\
\hline [lu.'lu] & Lulu \\
\hline [ka.'be.se] & Cabeça \\
\hline [sa.'pa.tu] & Sapato \\
\hline ['a.g $\left.{ }^{\mathrm{w}} \mathrm{e}\right]$ & Água \\
\hline ['fi.tu] & Filtro \\
\hline [‘bo.lu] & Bolo \\
\hline 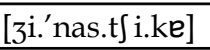 & Ginástica \\
\hline [ma. $\int$ u.'ka.du] & Machucado \\
\hline [ma.'xõ ] & Marrom \\
\hline
\end{tabular}

\section{Verbos}

\section{Produção Infantil}

\begin{tabular}{|c|c|}
\hline [be.'be] & Beber \\
\hline [ka.'iw] & Caiu \\
\hline$[\mathrm{k} \varepsilon]$ & Quero \\
\hline [fa.'ze] & Fazer \\
\hline [Se.'go] & Chegou \\
\hline ['va.mu] & Vamos \\
\hline [de.ze.'na] & Desenhar \\
\hline ['dzis.tu.'iw] & Destruiu \\
\hline [3u.'da] & Ajudar \\
\hline ['fe.Je] & Fecha \\
\hline [pe.'ga] & Pegar \\
\hline ['pq.ge] & Pega \\
\hline [Se.'ga] & Chegar \\
\hline
\end{tabular}

\section{Forma Alvo}




\begin{tabular}{|c|c|}
\hline [ta] & Está \\
\hline ['vẽ .du] & Vendo \\
\hline ['pe.le] & Espera \\
\hline [to] & Toma \\
\hline [to.'mo] & Tomou \\
\hline [go.'tej] & Gostei \\
\hline [ẽ .'xo.le] & Enrola \\
\hline [ko.'me] & Comer \\
\hline [ko.'me.rI] & Comerem \\
\hline [t $\int$ i.e $]$ & Tira \\
\hline [ẽ .si.'na] & Ensinar \\
\hline [a.ka.'bo] & Acabou \\
\hline [a.'biw] & Abriu \\
\hline ['go.tu] & Gosto \\
\hline [bo.'ta] & Botar \\
\hline [ko.'ta] & Cortar \\
\hline [ẽ .'ta] & Entrar \\
\hline [ka.'bẽ .du] & Cabendo \\
\hline [ma.Ju.'ka] & Machucar \\
\hline
\end{tabular}

\section{2;10. 21}

\section{Nomes}

\section{Produção Infantil}

Forma Alvo

\begin{tabular}{|c|c|}
\hline [ko] & Cor \\
\hline [ma.'sã] & Maçã \\
\hline [maj] & Mãe \\
\hline [ew] & $\mathrm{Eu}$ \\
\hline ['ba.nu] & Banho \\
\hline [u.'si.nu] & Ursinho \\
\hline ['pe.f I] & Peixe \\
\hline ['a.gwe] & Água \\
\hline [bo.'tãw] & Botão \\
\hline [se] & Você \\
\hline [es.'pe.lv] & Espelho \\
\hline ['mu.zi.ke] & Música \\
\hline [pa.'pa] & Pai \\
\hline [pa.'paj] & Pai \\
\hline [pe.'zẽ .t $[$ I] & Presente \\
\hline [bu.'ne.ke] & Boneca \\
\hline [lu.'lu] & Lulu \\
\hline [Se.'ro.zu] & Cheiroso \\
\hline [bu.'ne.ku] & Boneco \\
\hline [gof.'to.su] & Gostoso \\
\hline [vo.'le.te] & Violeta \\
\hline ['ka.me] & Cama \\
\hline ['xo.ze] & Rosa \\
\hline [kõ .fu.'zãw] & Confusão \\
\hline
\end{tabular}




\begin{tabular}{|l|l|}
\hline$[$ mo.'la.du] & Molhado \\
\hline$[$ fa.'zẽ .du] & Fazendo \\
\hline$\left[{ }^{\prime}\right.$ e.li $]$ & Ele \\
\hline
\end{tabular}

\section{Verbos}

\section{Produção Infantil}

Forma Alvo

\begin{tabular}{|c|c|}
\hline [fajs] & Faz \\
\hline [0] & Olha \\
\hline ['fa.le] & Fala \\
\hline ['ba.t $[$ I] & Bate \\
\hline$[\mathrm{k} \varepsilon]$ & Quero \\
\hline [to.'ma] & Tomar \\
\hline ['to.me] & Toma \\
\hline [ma.'Su.ke] & Machuca \\
\hline [fa.'ze] & Fazer \\
\hline [fa.'zẽ .dv] & Fazendo \\
\hline [ta] & Está \\
\hline ['de.Se] & Deixa \\
\hline [ve] & Ver \\
\hline [to.'ka] & Tocar \\
\hline [to] & Estou \\
\hline [to.'kã.du] & Tocando \\
\hline ['zã.du] & Usando \\
\hline [pe.'gej] & Peguei \\
\hline [de.ze.'na] & Desenhar \\
\hline [ta.'pa] & Tampar \\
\hline [Su.'vẽ .du] & Chovendo \\
\hline [ka.'iw] & Caiu \\
\hline [foj] & Foi \\
\hline ['kuj.de] & Cuida \\
\hline [bĩ l'ka] & Brincar \\
\hline [ko.'me] & Comer \\
\hline [dã.'as] & Dançar \\
\hline
\end{tabular}

\section{2;11.12}

Nomes

Produção Infantil

Forma Alvo

\begin{tabular}{|l|l|}
\hline$\left[{ }^{\prime} \mathrm{e} . \mathrm{lI}\right]$ & Ele \\
\hline$[\mathrm{p} \varepsilon]$ & Pé \\
\hline$\left[\mathrm{ma} .{ }^{\prime} \mathrm{mãj}\right]$ & Mamãe \\
\hline$\left[{ }^{\prime} \mathrm{ka} . \mathrm{le}\right]$ & Cara \\
\hline$\left[{ }^{\prime} \mathrm{l} \varepsilon . \mathrm{gu}\right]$ & Lego \\
\hline${ }^{\prime}$ du.ru $]$ & Duro \\
\hline
\end{tabular}




\begin{tabular}{|c|c|}
\hline [ko] & Cor \\
\hline [pe.ke.'ni.ne] & Pequenininha \\
\hline ['fu.te] & Fruta \\
\hline ['fes.te] & Festa \\
\hline [mãw] & Mão \\
\hline ['ka.ze] & Casa \\
\hline [de.'ze.nu] & Desenho \\
\hline ['ej.t $\mathrm{I}]$ & Leite \\
\hline ['bo.ke] & Boca \\
\hline [ka.'va.lu] & Cavalo \\
\hline ['ba.nu] & Banho \\
\hline ['su.zo] & Sujo \\
\hline [ko.'ko] & Cocô \\
\hline ['mũ.$d u]$ & Mundo \\
\hline [pa.'paj] & Pai \\
\hline ['bo.le] & Bola \\
\hline [ka.'zi.ne] & Casinha \\
\hline [xá.'t $t$ i.nu] & Ratinho \\
\hline ['pa.tu] & Pato \\
\hline ['po.ku] & Porco \\
\hline [So.ko.'a.t I I] & Chocolate \\
\hline [ba.'gũ .se] & Bagunça \\
\hline ['kaS.ke] & Casca \\
\hline ['xu.e] & Rua \\
\hline ['se.d3I] & Sede \\
\hline ['bo.e] & Boa \\
\hline ['no.t [ I] & Noite \\
\hline ['le.gu] & Lego \\
\hline
\end{tabular}

\section{Verbos}

\section{Produção Infantil}

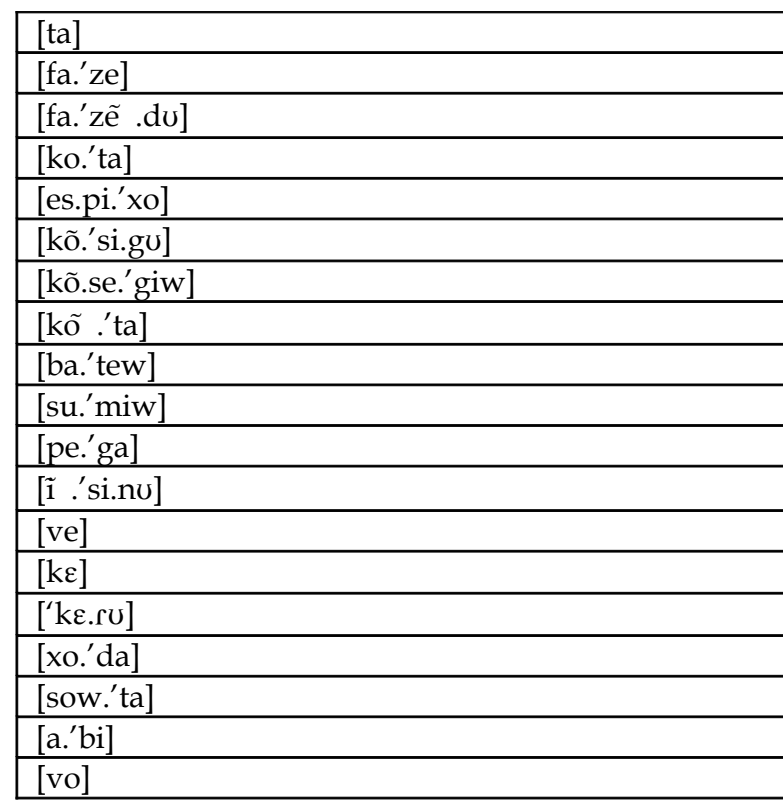

\section{Forma Alvo}

Está

Fazer

Fazendo

Cortar

Espirrou

Consigo

Conseguiu

Contar

Bateu

Sumiu

Pegar

Ensino

Ver

Quero

Quero

Rodar

Soltar

Abrir

Vou 


\begin{tabular}{|l|l|}
\hline$[\mathrm{o}]$ & Olha \\
\hline$[$ te.'na] & Treinar \\
\hline$[$ ke.'bo] & Quebrou \\
\hline [do.'mi] & Dormir \\
\hline [to.'ma] & Tomar \\
\hline ['jo.ge] & Joga \\
\hline [la.''va] & Lavar \\
\hline [na.'na] & Nanar \\
\hline [be.'be] & Beber \\
\hline [to] & Tomar \\
\hline
\end{tabular}

\section{3;0.9}

Nomes

Produção Infantil

Forma Alvo

\begin{tabular}{|c|c|}
\hline ['fes.te] & Festa \\
\hline ['e.lI] & Ele \\
\hline ['ka.ze] & Casa \\
\hline ['ba.nu] & Banho \\
\hline [bu.'ni.tu] & Bonito \\
\hline [dej.'ta.de] & Deitada \\
\hline ['xo.ze] & Rosa \\
\hline [pe.sa.'de.lu] & Pesadelo \\
\hline ['na.de] & Nada \\
\hline ['se.tes] & Certas \\
\hline [ba.'gũ .se] & Bagunça \\
\hline [bĩ .'ke.du] & Brinquedo \\
\hline$\left[{ }^{\prime} \mathrm{a} . \mathrm{g}^{\mathrm{w}} \mathrm{e}\right]$ & Água \\
\hline ['pa.tu] & Pato \\
\hline
\end{tabular}

\section{Verbos}

Produção Infantil

\begin{tabular}{|c|c|}
\hline [ta] & Está \\
\hline [fa.'ze] & Fazer \\
\hline [fa.'zẽ.dv] & Fazendo \\
\hline$\left[{ }^{\prime} \mathrm{k} \varepsilon . v\right]$ & Quero \\
\hline ['va.mu] & Vamos \\
\hline [vê] & Ver \\
\hline [to.'mo] & Tomou \\
\hline [ko.'me] & Comer \\
\hline [ko.'briw] & Cobriu \\
\hline [ba.lã.'sã.du] & Balançando \\
\hline [’o.Ke] & Olha \\
\hline [t $\int$ i.'rã.du] & Tirando \\
\hline
\end{tabular}




\begin{tabular}{|l|l|}
\hline$\left[{ }^{\prime} \mathrm{le} . \mathrm{b} u\right]$ & Lembro \\
\hline ['va.mu] & Vamos \\
\hline$[$ ko.'mẽ $\cdot \mathrm{du}]$ & Comendo \\
\hline [ẽ .pu.'xo] & Empurrou \\
\hline
\end{tabular}

